\author{
UNIVERSIDADE DE SÃO PAULO \\ ESCOLA DE ENGENHARIA DE SÃO CARLOS \\ DEPARTAMENTO DE GEOTECNIA
}

\title{
EMPREGO DO MÉTODO SIM PARA OBTENÇÃO DAS CURVAS ISÓCRONAS E DE RUPTURA POR FLUENCIA
}

\begin{abstract}
MARCIO ANTONIO COSTANZI
Dissertação apresentada à Escola de Engenharia de São Carlos, da Universidade de São Paulo, como parte dos requisitos para obtenção do Título de Mestre em Geotecnia
\end{abstract}

ORIENTADOR: PROF. DR. BENEDITO DE SOUZA BUENO 
Aos meus pais, Renato e Elzira; às minhas irmãs, Helena e Sandra;

dedico esta dissertação 


\section{AGRADECIMENTOS}

Ao Professor Benedito de Souza Bueno, pela sua dedicação, ensinamentos, amizade e excelente orientação.

À Ober pela doação do material de pesquisa..

Ao engenheiro Dr. Maurício Abramento e professor Dr. Orêncio Monje Vilar, pelas sugestões e colaborações apresentadas no exame de qualificação.

Aos funcionários do Departamento de Geotecnia, em especial aos técnicos Clever e Sílvio do laboratório de Geossintéticos.

A todos os colegas do departamento pela sincera colaboração e dedicação, em especial a Érika Mendes de Sá pela sua inestimável amizade e apoio.

Aos amigos de república, Ronaldo, Luís, Paulo, Cristiano, Alexandre, Alan e Mateus pela grande amizade e incentivo em todos o momentos.

E, principalmente, à minha família, Renato Antonio Costanzi, Elzira Gineste Costanzi, Helena Maria Costanzi Nader e Sandra Maria Gineste Costanzi, que são os grandes responsáveis por mais esta conquista na minha vida. 


\section{SUMÁRIO}

RESUMO.

i

ABSTRACT

LISTA DE FIGURAS............................................................................... iii

LISTA DE TABELAS.................................................................................................... vii

1 - INTRODUÇÃO................................................................................ 1

1.1 - OBJETIVOS DO TRABALHO............................................................... 3

1.2 - ORGANIZAÇÃO DO TRABALHO.................................................... 3

2 - REVISÃO BIBLIOGÁFICA................................................................. 4

2.1 - A FLUÊNCIA NO DIMENSIONAMENTO DE MUROS E TALUDES DE SOLO REFORÇADO..............................................

2.2 - CONCEITOS BÁSICOS DE FLUÊNCIA........................................... 6

2.3 - FATORES QUE INFLUENCIAM A MAGNITUDE DA FLUÊNCIA EM GEOTÊXTEIS NÃO TECIDOS.............................

2.3.1 - Tipo de polímero......................................................................... 8

2.3.2 - Tipo de geotêxtil quanto à forma de fabricação............................ 10

2.3.3 - Nível de carregamento.......................................................... 10

2.3.4 - Presença de Confinamento............................................................ 12

2.3 .5 - Temperatura.......................................................................... 14

2.4 - CARACTERIZAÇÃO DA FLUÊNCIA........................................... 16

2.4.1 - Modelos reológicos.................................................................. 20

2.4.2 - Extrapolações com as equações de Arrhenius e Williams-Landel-

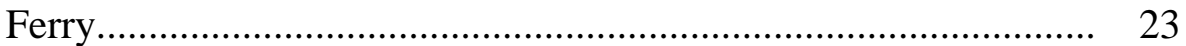


2.5 - ENSAIOS ACELERADOS DE FLUÊNCIA..................................... 24

2.5.1 - Ensaios acelerados de fluência do tipo convencional.................... 24

2.5.2 - Ensaios acelerados de fluência do tipo “Stepped Isothermal Method (SIM)" ........................................................................ 28

2.5.3 - Ensaios acelerados de ruptura por fluência................................... 31

3 - MATERIAIS E MÉTODOS.................................................................. 33

3.1 - MATERIAIS UTILIZADOS............................................................... 33

3.2 - PREPARAÇÃO DOS CORPOS DE PROVA..................................... 34

3.3 - EQUIPAMENTO PARA EXECUÇÃO DOS ENSAIOS 35 CONVENCIONAIS DE FLUÊNCIA..............................................

3.4 - EQUIPAMENTO PARA EXECUÇÃO DOS ENSAIOS

3.4.1 - A câmara de temperatura controlável......................................... 36

3.4.2 - Cavalete metálico para execução dos ensaios acelerados.............. 37

3.5 - SISTEMA DE ANCORAGEM E DE APLICAÇÃO DE CARGAS 37

3.6 - EQUIPAMENTO UTILIZADO PARA EXECUTAR OS 40 ENSAIOS DE RUPTURA POR FLUÊNCIA CONVENCIONAL.

3.7 - SISTEMA DE LEITURA DOS ALONGAMENTOS........................ 41

3.8 - PROCEDIMENTOS DOS ENSAIOS CONVENCIONAIS DE 44

3.9 - PROCEDIMENTOS DOS ENSAIOS ACELERADOS DE 44

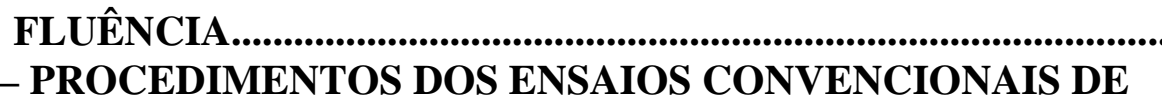

3.11 - PROCEDIMENTOS DOS ENSAIOS CONVENCIONAIS DE RUPTURA POR FLUENCIA

4 - APRESENTAÇÃO E ANÁLISE DOS RESULTADOS......................... 48

4.1 - ENSAIOS DE FLUÊNCIA.............................................................. 48

4.1 .1 - Fluência do geotêxtil A............................................................. 48

4.1.2 - Fluência do geotêxtil B............................................................ 54

4.1.3 - Curvas isócronas dos geotêxteis ensaiados................................. 59 
4.1.4 - Deformação transversal das amostras dos geotêxteis ensaiados.... 60

4.1.5 - Avaliação da taxa de deformação por fluência do material utilizando a equação WLF........................................................... 63

4.2 -ENSAIOS DE RUPTURA POR FLUÊNCIA...................................... 65

4.2.1 - Ensaios de ruptura por fluência do material A............................. 65

4.2.2 - Ensaios de ruptura por fluência do material B............................. 67

4.2.3 - Fatores de redução para ruptura por fluência nos geotêxteis ensaiados

4.2.4 - Fatores de redução para ruptura por fluência nos geotêxteis ensaiados considerando-se incertezas da extrapolação.....

5 - CONCLUSÕES E SUGESTÕES PARA PESQUISAS FUTURAS......... 74

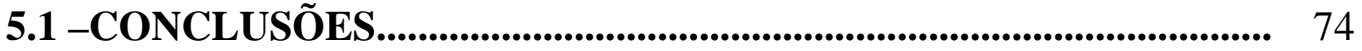

5.2 - SUGESTÕES PARA PESQUISAS FUTURAS............................... 75

REFERÊNCIAS BIBLIOGRÁFICAS............................................................. 76 


\section{RESUMO}

\section{COSTANZI, M. A. (2003). Emprego do Método SIM para Obtenção das} Curvas Isócronas e de Ruptura por Fluência. Dissertação (Mestrado) Escola de Engenharia de São Carlos, Universidade de São Paulo.

A obtenção de resultados de fluência em geossintéticos (isócronas e curva de ruptura por fluência) requer longo tempo de observação e rigoroso controle laboratorial. Dessa forma, muitos produtos disponíveis no mercado brasileiro não foram ensaiados quanto a este fenômeno dificultando sobremaneira a elaboração de projetos mais seguros e econômicos. Há, portanto, a necessidade de estudos não só do fenômeno da fluência em si, mas também de métodos de ensaio que facilitem e acelerem a obtenção das curvas de fluência. Este trabalho apresenta um estudo da fluência de dois geotêxteis não tecidos, um de polipropileno e outro de poliéster, através de ensaios acelerados, utilizando-se o processo denominado Stepped Isothermal Method (SIM). Os valores obtidos pelo método SIM foram comparados aos valores obtidos nos ensaios convencionais, realizados segundo a norma ISO 13431. Os resultados experimentais indicam que os ensaios acelerados, utilizando o método SIM, foram capazes de simular o fenômeno da fluência com boa precisão e, portanto, podem trazer uma grande economia de tempo, além de facilitar e agilizar a caracterização da fluência de geossintéticos.

Palavras-chave: Ensaios de fluência não confinados, ensaios de fluência acelerados, Stepped Isothermal Method (SIM), geotêxteis não tecidos. 


\section{ABSTRACT}

COSTANZI, M. A. (2003). Emprego do Método SIM para Obtenção das Curvas Isócronas e de Ruptura por Fluência. Dissertação (Mestrado) Escola de Engenharia de São Carlos, Universidade de São Paulo.

Creep tests are time consuming and require rigorous laboratory testing control. Because of that many products commercially available in Brazil were not tested regarding this phenomenon. The absence of creep data is an obstacle to the design soil reinforced structures. It is therefore required continuous research effort not only to elucidate creep phenomenon but also to help in the development of test methods that ease and speed up the obtaining of creep curves. This paper presents a creep study carried out on two non-woven geotextiles (PP and PET) using temperature accelerated creep test, namely the Stepped Isothermal Method (SIM). The values obtained using the SIM method were compared to the ones obtained using conventional creep tests following the ISO 13431. The experimental results indicate that the accelerated creep tests, using the SIM method, were capable of simulating the creep phenomenon with good accuracy and, hence, they can bring a great deal of time saving to the characterization of creep in geosynthetics.

Keywords: Unconfined creep test, temperature accelerated creep test, Stepped Isothermal Method (SIM), Non-Woven geotextile. 


\section{LISTA DE FIGURAS}

FIGURA 2.1 - $\quad$ Modelo típico de fluência................................................................ 7

FIGURA 2.2 - Fluência para carregamento de 60\% (DEN HOEDT, 1986).......... 9

FIGURA 2.3 - $\quad$ Fluência para carregamento de 20\% (DEN HOEDT, 1986)........... 9

FIGURA 2.4 - Deformação total x tempo para geotêxtil não tecido de poliéster de filamentos contínuos (COSTA, 1999)....................................... 11

FIGURA 2.5 - Deformação total x tempo para geotêxtil não tecido do polipropileno de fibras cortadas (COSTA, 1999)........................... 11

FIGURA 2.6 - Resultados de ensaios de fluência em geotêxteis não tecidos (McGOWN et al., 1982)............................................................... 13

FIGURA 2.7 - C C Curva carga x deformação para sistema silte-geotextil (TUPA \& PALMEIRA, 1995).....

FIGURA 2.8 - Variação da rigidez secante com a deformação para o sistema silte-geotêxtil (TUPA \& PALMEIRA, 1995).

FIGURA 2.9 - $\quad$ Esquema da variação do volume específico vs. Temperatura (relativo ao volume específico em Tg). (modificado de FERRY, 1980).

FIGURA 2.10 - Obtenção das curvas isócronas (BARAS, 2001).

FIGURA 2.11 - O Obtenção da resistência à tração de um geotêxtil a partir da curva de ruptura por fluência (BARAS, 2001).

FIGURA $2.12-$

(a) Primeiro modelo reológico (b) Curva de fluência com descarregamento parcial (SAWICKI \& KAZIMIEROWICZFRANKOWSKA, 1998).

FIGURA $2.13-$

(a) Segundo modelo reológico (b) Curva de fluência com descarregamento parcial (SAWICKI \& KAZIMIEROWICZFRANKOWSKA, 1998). 
FIGURA 2.14 - Modelo reológico de Kelvin-Chain (KOERNER et al., 2001)......

FIGURA 2.15 - $\quad$ Resultados de ensaios de fluência em geogrelha de PEAD em 4 diferentes temperaturas (FARRAG \& SHIRAZI, 1997)................ 25

FIGURA 2.16 - Curva de fluência obtida para ensaio acelerado convencional (FARRAG, 1998)

FIGURA 2.17 - Curva de fluência obtida para ensaio acelerado convencional (FARRAG, 1998)

FIGURA 2.18 - Fatores de translação calculados pela equação WLF (FARRAG, 1998).

FIGURA 2.19 - $\quad$ Fatores de translação obtidos graficamente (FARRAG, 1998)...... $\quad 27$

FIGURA $2.20-\quad 1^{\circ}$ passo do método SIM (BARAS, 2001).................................... 29

FIGURA $2.21-\quad 2^{\circ}$ passo do método SIM (BARAS, 2001).................................... 29

FIGURA $2.22-\quad 3^{\circ}$ passo do método SIM (BARAS, 2001)..................................... 30

FIGURA $2.23-\quad 4^{\circ}$ e $5^{\circ}$ passos do método SIM (BARAS, 2001)............................ 30

FIGURA 2.24 - C Curva de ruptura por fluência obtidas com vários corpos de prova (GREENWOOD \& VOSKAMP, 2000)............................... 31

FIGURA 3.1 - $\quad$ Corpo de prova antes e depois da colagem na peça da garra......... 35

FIGURA 3.2 - $\quad$ Cavalete individual para ensaios de fluência................................... 35

FIGURA 3.3 - C Câmara de temperatura controlável................................................. 37

FIGURA 3.4 - $\quad$ Conjunto garra/geotêxtil utilizada nos ensaios............................... 38

FIGURA 3.5 - $\quad$ Sistema de aplicação de carga em ensaio montado........................ 39

FIGURA 3.6 - $\quad$ Macaco hidráulico do tipo jacaré.................................................... 39

FIGURA 3.7 - $\quad$ Macaco hidráulico do tipo girafa.................................................... 40

FIGURA 3.8 - $\quad$ Presa, célula de carga e garra utilizados nos ensaios de ruptura por fluência...................................................................................... 41

FIGURA 3.9 - $\quad$ Tela principal do programa TRATAMENTO................................ 43

FIGURA 4.1 - C Curvas das deformações por fluência em função do tempo para 10, 20, 40 e $60 \%$ UTS obtidas com ensaios acelerados no geotêxtil A 
FIGURA 4.2 - C Curvas dos módulos de fluência em função do tempo para 10, 20, 40 e $60 \%$ UTS obtidas com ensaios acelerados para o geotêxtil A

FIGURA 4.3 - Curvas mestras obtidas pelo SIM e curvas convencionais para 10, 20, 40 e 60\% UTS para o geotêxtil A

FIGURA 4.4 - Curvas mestras do módulo de fluência obtidas pelo SIM e curvas convencionais para 10, 20, 40 e 60\% UTS para o geotêxtil A........

FIGURA 4.5 - C Curvas das deformações por fluência em função do tempo para 10, 20, 40 e $60 \%$ UTS obtidas com ensaios acelerados no geotêxtil B

FIGURA $4.6-$ Curvas dos módulos de fluência em função do tempo para 10, 20, 40 e $60 \%$ UTS obtidas com ensaios acelerados para o geotêxtil B.

FIGURA 4.7 Curvas mestras obtidas pelo SIM e curvas convencionais para 10, 20, 40 e 60\% UTS para o geotêxtil B.

FIGURA 4.8 - C Curvas mestras do módulo de fluência obtidas pelo SIM e curvas convencionais para 10, 20, 40 e 60\% UTS para o geotêxtil B....... 56

FIGURA 4.9 - Curvas isócronas para o geotêxtil A, obtidas dos ensaios 3A, 6A, $13 \mathrm{~A}$ e $16 \mathrm{~A}$

FIGURA 4.10 - Curvas isócronas para o geotêxtil B, obtidas dos ensaios 4B, 6B, 11B e $15 \mathrm{~B}$

FIGURA 4.11 - Esquema da estricção ou encurtamento do material na dimensão horizontal no centro do corpo de prova

FIGURA 4.12 - Curvas de Estricção obtidas para o material A, para 10, 20, 40 e $60 \%$ UTS.

FIGURA 4.13 - Curvas de Estricção obtidas para o material B, para 10, 20, 40 e $60 \%$ UTS.

FIGURA 4.14 - Curvas Fatores de ajustes, $\alpha$ t, analíticos e experimentais do material A

FIGURA 4.15 - Curvas Fatores de ajustes, $\alpha$ t, analíticos e experimentais do material B 
FIGURA 4.16 - Curva de ruptura obtida com uma combinação de resultados de ensaios convencionais e acelerados do material A.

FIGURA 4.17 - Curva de ruptura obtida com uma combinação de resultados de ensaios convencionais e acelerados do material A.

FIGURA 4.18 - Curva de ruptura e Curva do Limite de Confiança de 95\% do material A.

FIGURA 4.19 - C Curva de ruptura e Curva do Limite de Confiança de 95\% do material B. 


\section{LISTA DE TABELAS}

TABELA 2.1 - Fatores de redução por efeito da fluência (KOERNER, 1994)......... 6

TABELA 3.1 - Características de fabricação dos geotêxteis ensaiados....................... 33

TABELA 3.2 - Resultados da caracterização dos geotêxteis ensaiados.................... 34

TABELA 4.1 - Resultados dos tempos de alcance do geotêxtil A............................ 52

TABELA 4.2 - Coeficientes obtidos por regressão linear para as curvas do geotêxtil A.................................................................................. 53

TABELA 4.3 - $\quad$ Resultados dos tempos de alcance do geotêxtil B............................. 57

TABELA 4.4 - Coeficientes obtidos por regressão linear para as curvas do geotêxtil B................................................................................... 58

TABELA 4.5 - Tempos de Ruptura obtidos para o geotêxtil A................................. 66

TABELA 4.6 - Tempos de Ruptura obtidos para o geotêxtil B................................. 68

TABELA 4.7 - Fatores de redução em virtude da fluência para o geotêxtil A e B.... 70

TABELA 4.8 - Fatores de redução em virtude da fluência para o geotêxtil A e B considerando-se as incertezas das extrapolações e dos ensaios acelerados 


\section{CAPÍTULO 1}

\section{INTRODUÇÃO}

Na maioria das aplicações, os geossintéticos são submetidos a esforços de tração de longa duração. Sob este efeito, estes materiais sofrem fluência, i.e., deformam-se ao longo do tempo sob carregamento constante. Em vista disto, a fluência em geossintéticos é importante e deve ser adequadamente considerada nos projetos.

Por ser um fenômeno acentuado em materiais poliméricos e tendo em vista que ocorre à temperatura ambiente, se não for devidamente quantificado, pode induzir deformações excessivas indesejáveis. No caso de solo reforçado, a fluência pode levar o sistema ao colapso pela ruptura das inclusões. As deformações por fluência para um dado material podem ser estimadas através das curvas mestras de fluência e o risco de colapso, pela curva de ruptura por fluência.

Os procedimentos convencionais de ensaio para a determinação da curvas mestra de fluência prescrevem 1000 horas (ISO 13431) ou 10000 horas (ASTM D 5262) de observação. Estes ensaios consistem na aplicação de um carregamento constante em um ambiente com temperatura e umidade controladas, onde os registros dos deslocamentos verticais das amostras são obtidos com o tempo. Isto permite definir curvas de fluência que correlacionam o tempo, em escala logarítmica, e deformação, para um determinado carregamento (THORNTON et al., 1997; THORNTON, 1998; FARRAG e SHIRAZI, 1997; FARRAG, 1998; BARAS, 2001). Um conjunto de curvas mestras permite a determinação das curvas isócronas do material que correlacionam carga versus deformação para um dado tempo de vida útil da obra (COSTA, 1999; BARAS, 2001; BARAS et al., 2002).

Para se definir a curva de ruptura por fluência, aplicam-se cargas constantes, em geral tomadas como uma fração da carga que leva o corpo de prova à ruptura no ensaio de tração 
em faixa larga (NBR-12824) e registram-se os tempos para a quebra das amostras. Os valores de carga aplicada versus tempo de quebra, em escala logarítmica, se alinham, dando origem à curva de ruptura por fluência. Assim, definindo-se um tempo de vida útil para a obra é possível prever a carga que deveria ser aplicada ao geossintético para provocar-lhe a ruptura por quebra.

Considerando o longo tempo necessário para execução da maioria dos ensaios convencionais de fluência, muitos materiais comercializados rotineiramente no Brasil não dispõem de seus resultados. Portanto, qualquer tentativa de se acelerar a determinação da fluência em geossintéticos é de grande valia. Neste contexto, alguns pesquisadores têm utilizado recursos experimentais e de tratamento de resultados já consagrados na engenharia de polímeros, para acelerar os tempos de observação dos ensaios de fluência. O referido processo denomina-se princípio da superposição tempo-temperatura (STT ou ainda TTS, abreviatura inglesa do princípio)

Na presente dissertação, o princípio TTS foi utilizado conjuntamente com o método SIM (Stepped Isothermal Method) para acelerar os tempos de observação nos ensaios de fluência laboratoriais em dois geotêxteis não tecidos fabricados no país, com fibras curtas e agulhados, um de poliéster (PET) e outro de polipropileno (PP).

Os ensaios foram realizados no Laboratório de Geossintéticos, do Departamento de Geotecnia da USP em São Carlos que dispõe de um equipamento próprio o qual permite ensaiar geossintéticos em um ambiente de temperaturas elevadas. Neste trabalho, será dada ênfase à influência da temperatura, em face de sua relação direta com o desenvolvimento e interpretação dos resultados dos ensaios acelerados. Discussões sobre as interferências dos demais fatores na fluência de geotêxteis podem ser encontrados em COSTA e BUENO (2001), COSTA (1999) e BARAS (2001). 


\subsection{Objetivos do trabalho}

Este trabalho teve por objetivos:

a) avaliar a utilização do princípio de superposição tempo-temperatura conjuntamente com o método "Stepped Isothermal Method” na caracterização e simulação do comportamento da fluência e da ruptura por fluência em dois geotêxteis não tecidos;

b) analisar a estricção nos ensaios de fluência acelerados como método de validação dos ensaios acelerados;

c) determinar e comparar os fatores de redução da resistência à tração com a bibliografia existente.

\subsection{Organização do trabalho}

Além deste capítulo, a presente dissertação comporta mais 4 divisões. O capítulo 2 apresenta uma revisão bibliográfica da literatura referente à fluência, principalmente abordando os ensaios acelerados do tipo SIM.

No capítulo 3, são mostrados os equipamentos e mecanismos utilizados para a realização dos ensaios convencionais e acelerados, os materiais ensaiados e por fim os procedimentos adotados nos testes.

Já no capitulo 4, são dispostos os resultados dos ensaios, procedendo-se uma análise dos resultados. Finalmente, no capítulo 5 expõem-se as principais conclusões obtidas na dissertação e apresentam-se sugestões para pesquisas futuras. 


\section{CAPÍTULO 2}

\section{REVISÃO BIBLIOGRÁFICA}

Este capítulo apresenta os princípios gerais e aspectos relacionados à fluência em materiais geossintéticos. Além disto, introduz o método acelerado do tipo "Stepped Isothermal Method”, ou SIM, para a obtenção de curvas isócronas e de ruptura por fluência em geotêxteis não tecidos.

\subsection{A importância da fluência em obras de solo reforçado.}

A utilização de geossintéticos em obras de engenharia civil, sobretudo para reforço de solo, tem crescido em todo o mundo devido ao excelente desempenho, versatilidade, fácil emprego, facilidade de transporte e, principalmente, ao baixo custo quando comparada às soluções tradicionais. As economias geradas podem atingir, em soluções de solo reforçado, de 10 a 50\%, sendo que para as piores condições do solo de apoio se obtém os maiores percentuais, devido à pequena sensibilidade a recalques diferenciais (CRISTOPHER et al., 1990).

O geotêxtil pode exercer uma ou mais funções nas obras civis. Além de reforçar o solo em muros e taludes, os geotêxteis podem atuar como filtros em drenos, como separador de materiais e como reforço em aterros sobre solo mole.

Para o dimensionamento de solos reforçados são estudadas as condições de estabilidade interna e externa do maciço. A estabilidade externa é tratada da mesma forma que a de estruturas convencionais de contenção como muros de arrimo, muros de flexão, gabiões e muros de gravidade, considerando-se ruptura por tombamento e deslizamento na base da estrutura, capacidade de carga do solo de fundação e ruptura geral por superfícies de deslizamento envolvendo o maciço reforçado. A análise de estabilidade interna envolve a 
ruptura e o arrancamento das inclusões. A ruptura é analisada comparando-se a solicitação esperada em cada inclusão com a resistência à tração de projeto.

Há rotineiramente duas maneiras de se definir a resistência à tração de projeto: estado limite último (resistência à tração do geotêxtil ao final da vida útil da obra, obtida através das curvas de ruptura por fluência) ou estado limite de utilização (quando é necessário limitar as deformações do geossintético, através das curvas isócronas de fluência).

A prática comum, de dimensionamento, incorpora a utilização do conceito de resistência admissível $\left(\mathrm{T}_{\mathrm{adm}}\right)$. Esse parâmetro é a relação da resistência última à tração, obtida através de ensaios rápidos de tração, minorada por fatores de redução, como pode ser visto na equação 2.1, descrita por KOERNER (1994):

$$
T_{a d m}=\frac{T_{u l t}}{F R_{D I} \cdot F R_{F L} \cdot F R_{D Q} \cdot F R_{D B}}
$$

Sendo:

$\mathrm{T}_{\text {ult }}$ : Resistência última à tração:

FR $_{\mathrm{DI}}$ : Fator de redução devido a danos de instalação na obra;

$\mathrm{FR}_{\mathrm{FL}}$ : Fator de redução devido à fluência do material;

$\mathrm{FR}_{\mathrm{DQ}}$ : Fator de redução devido à degradação química do material;

$\mathrm{FR}_{\mathrm{DB}}$ : Fator de redução devido à degradação biológica o material.

Exemplo dos fatores de redução, usualmente empregados na prática, são encontrados em Koerner (1994). O fator de redução devido à fluência corresponde à relação entre a carga de ruptura convencional e a carga de ruptura em função desse mecanismo (estado limite último) ou a carga para uma determinada deformação (estado limite de utilização). Na prática, na maioria das vezes, não existem resultados de ensaios de fluência, portanto são utilizados parâmetros indicados pela literatura, o que torna o procedimento muito conservador. KOERNER (1994) apresenta uma síntese dos valores de Fatores de Redução por fluência ( $\left.\mathrm{FR}_{\mathrm{FL}}\right)$, conforme vários autores, Tabela 2.1: 
TABELA 2.1 - Fatores de redução por efeito da fluência (KOERNER, 1994).

\begin{tabular}{|c|c|c|c|}
\hline Polímero & Den Hoedt (1986) & Lawson (1986) & Koerner (1994) \\
\hline Polipropileno (PP) & 4,0 & 2,5 a 5,0 & 3,0 a 4,0 \\
\hline Polietileno (PE) & 4,0 & 2,5 a 5,0 & 3,0 a 4,0 \\
\hline Poliamida (PA) & 2,5 & 1,5 a 2,5 & 2,0 a 2,5 \\
\hline Poliéster (PET) & 2,0 & 1,5 a 2,5 & 2,0 a 2,5 \\
\hline
\end{tabular}

Para uma avaliação criteriosa de $\mathrm{FR}_{\mathrm{FL}}$ é necessária a obtenção das curvas de fluência do material, através de ensaios de laboratório. Esses ensaios são, em sua maioria, onerosos por demandarem longo tempo de observação e laboratórios com ambiente controlado. Em vista disto, há no Brasil uma enorme carência de estudos de fluência executados sobre os materiais fabricados pela indústria nacional. Além disto, é oportuno os estudos de métodos experimentais e de interpretação de resultados que facilitem e acelerem a obtenção das curvas de fluência. Este estudo, como mostrado no capítulo anterior, vem de encontro destas necessidades.

\subsection{Conceitos básicos de fluência.}

Em engenharia, o termo fluência refere-se às deformações viscosas causadas pela ação de carregamento constante e de longa duração aplicado a um corpo qualquer. A fluência, no caso dos geossintéticos, pode ser definida como a aptidão do material em alongar-se sob carregamento estático de longa duração (ABRAMENTO, 1995). Ainda, segundo CAZZUFFI et al. (1997), fluência é o comportamento elasto-viscoplástico dos geossintéticos, que sofrem deformações ao longo do tempo devido a carregamento constante. Esses carregamentos constantes podem produzir deformações por fluência nas fibras dos geossintéticos e subseqüente relaxação por tensão (KOERNER et al., 1988).

A fluência pode ser dividida em 3 fases (MÜLLER-ROCHHOLZ \& KOSLOWSKI, 1996; CAZZUFFI et al., 1997; MIKI et al., 1990) como pode ser visto na Figura 2.1: 
- FLUÊNCIA PRIMÁRIA: as deformações se desenvolvem rapidamente, ao passo que a taxa de deformação decresce. Quando plotado em escala logarítmica de tempo esse trecho apresenta comportamento linear;

- FLUÊNCIA SECUNDÁRIA: nesse estágio a taxa de deformação decresce muito lentamente até atingir um valor mínimo. Quando plotado em escala aritmética de tempo esse trecho apresenta-se linear;

- FLUÊNCIA TERCIÁRIA: estágio, que começa após o valor mínimo de deformação da fluência secundária, é caracterizado pelo rápido aumento da taxa de deformação, culminando com falha ou ruptura.

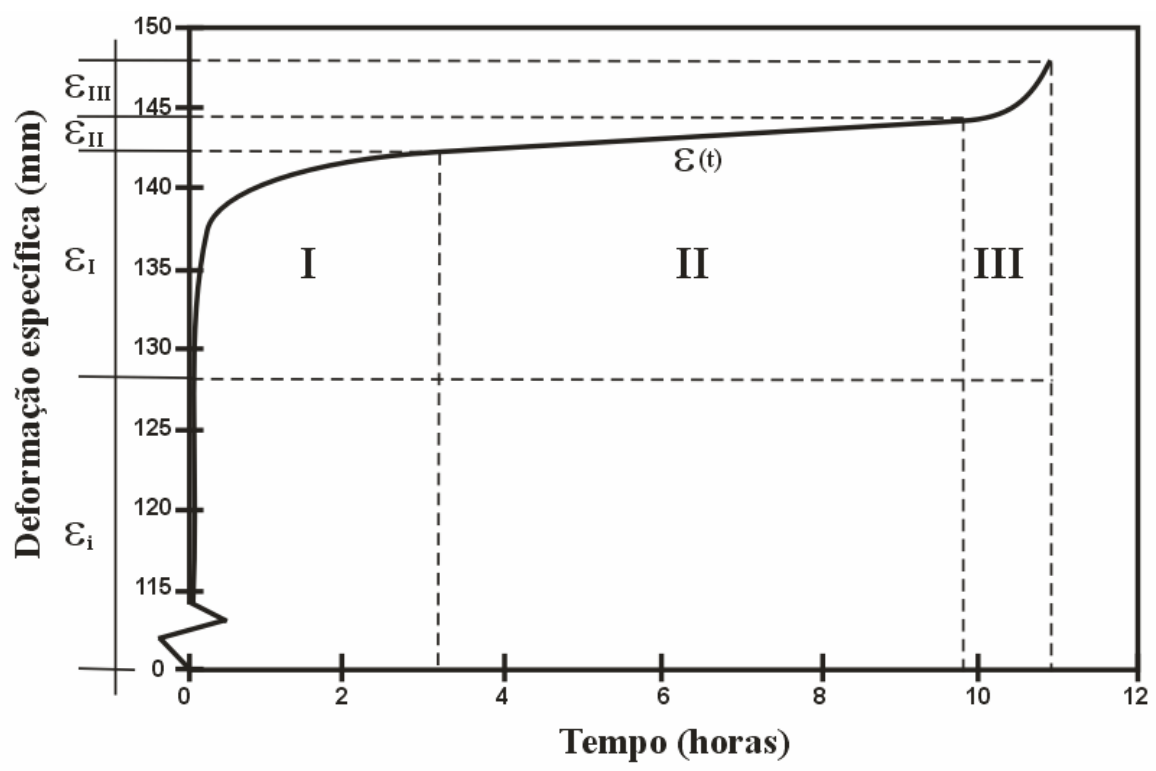

FIGURA 2.1 - Modelo típico de fluência.

A deformação total $\left(\varepsilon_{(\mathrm{t})}\right)$ pode ser expressa pela seguinte equação:

$\varepsilon_{(\mathrm{t})}=\varepsilon_{\mathrm{i}+} \varepsilon_{\mathrm{I}+} \varepsilon_{\mathrm{II}}+\varepsilon_{\mathrm{III}}$

Onde:

- $\quad \varepsilon_{\mathrm{i}}=$ deformação instantânea composta por uma parte recuperável (elástica) e uma parte irrecuperável (plástica) que ocorre assim que o geossintético é carregado;

- $\quad \varepsilon_{\mathrm{I}}=$ deformação devido à fluência primária;

- $\quad \varepsilon_{\text {II }}=$ deformação devido à fluência secundária;

- $\quad \varepsilon_{\text {III }}=$ deformação devido à fluência terciária; 
Dependendo do tipo de geossintético, uma ou outra fase pode ser mais evidente, mas a maioria dos materiais poliméricos utilizados na fabricação destes, flui, em maior ou menor escala. A magnitude da fluência depende não só da matéria prima e do método de fabricação utilizada, mas também do nível de carregamento aplicado e da temperatura do meio ambiente onde o geossintético está inserido (DEN HOEDT, 1986). Esses fatores serão mais bem explicados a seguir.

\subsection{Fatores que influenciam a fluência em geotêxteis não tecidos.}

\subsubsection{Tipo de polímero.}

Os materiais poliméricos são formados por cadeias moleculares longas a partir de unidades de repetição denominadas monômeros. Estas cadeias podem assumir formas geométricas de relativa complexidade e estarem unidas umas às outras através de ligações cruzadas. Além disto, o corpo polimérico pode apresentar áreas de grande orientação molecular (áreas semi-cristalinas) e regiões onde prevalecem um arranjo aleatório entre as macromoléculas (zonas amorfas).

O grau de orientação cristalina e a percentagem de zonas amorfas, somada à temperatura de transição vítrea ditam o comportamento das propriedades do polímero (VAN ZANTEN, 1986; DEN HOEDT, 1986; HORROCZ \& D'SOUZA, 1992).

O comportamento tensão $\mathrm{x}$ deformação (curto prazo) é determinado pela deformação das regiões amorfas. Já em caso de carregamento prolongado (fluência) a parte cristalina é a mais importante para o comportamento dos geossintéticos. Quanto mais cristalino é o polímero maior é sua resistência mecânica e maior é sua susceptibilidade à fluência.

Entre os materiais utilizados, normalmente, na fabricação de geotêxteis, o polipropileno tem de 70 a $80 \%$ de áreas cristalinas, o polietileno 75 a $85 \%$ e o poliéster 30 a $40 \%$. A influência do tipo de polímero na magnitude da fluência pode ser visualizada nas Figuras 2.2 e 2.3 (DEN HOEDT, 1986), onde o valor mostrado no eixo das abscissas é o exponencial de 10. Pode-se observar que para todos os polímeros do grupo das poliolefinas, PP e PE, a curva de fluência apresenta crescimento assintótico antes de se atingir a ruptura, 
principalmente quando tais materiais estão sujeitos a cargas de tração elevadas. O poliéster, por sua vez, menos cristalino, apresenta menor fluência (relação linear).

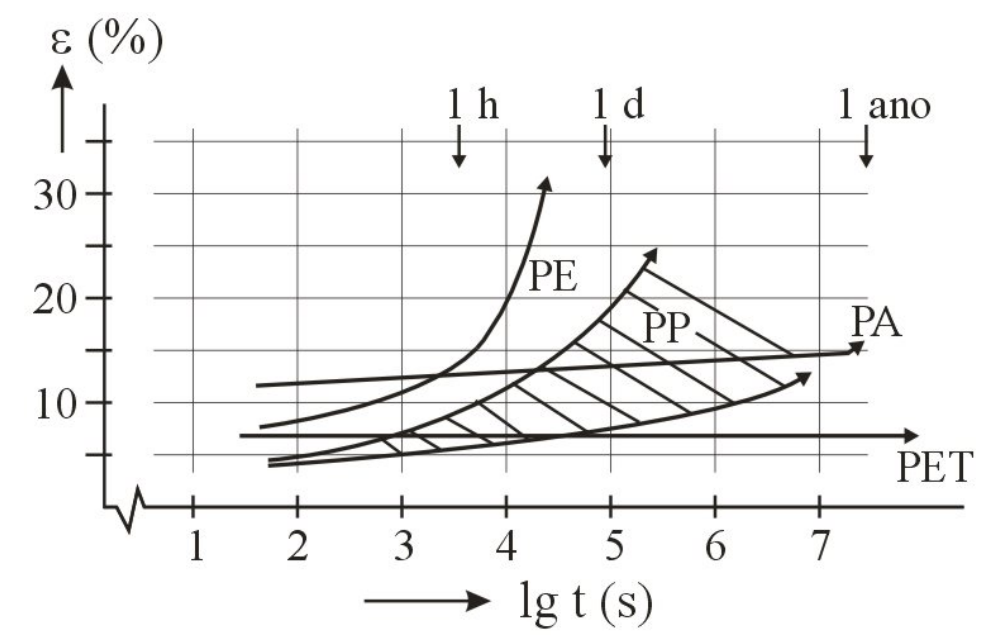

FIGURA 2.2 - Fluência para carregamento de 60\% (DEN HOEDT, 1986).

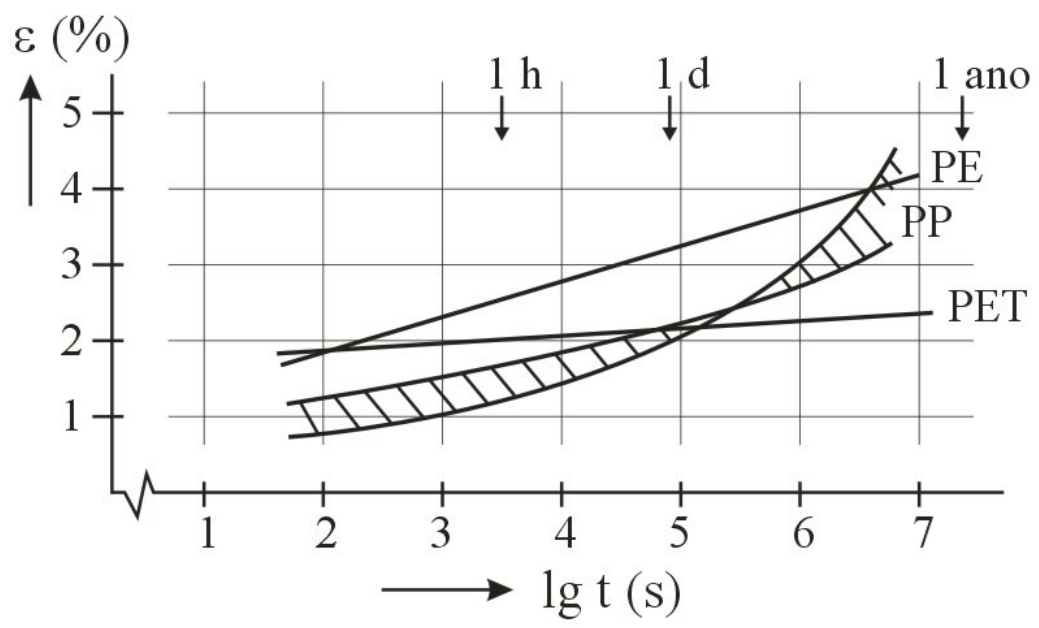

FIGURA 2.3 - Fluência para carregamento de 20\% (DEN HOEDT, 1986).

Dos muitos materiais utilizados para a confecção dos geossintéticos, CAZZUFFI et al. (1997) ordenaram a susceptibilidade à fluência dos polímeros PP, PE e PET. O menos susceptível segundo os autores é o PET, seguido do PP e o mais susceptível é o PE. DEN HOEDT (1986), por sua vez, ordenou os polímeros PP, PA e PET, e segundo ele o menos susceptível é o PET, seguido da PA e finalmente o PP.

A fluência do polipropileno (PP) é muito alta devido a sua baixa temperatura de transição vítrea (Tg) (HORROCZ \& D'SOUZA, 1992). A fluência dos geotêxteis de 
poliéster é bem menor em relação aos de polipropileno (cerca de 10 vezes) para um carregamento de 40\% de sua resistência à tração (COSTA, 1999). Na maior parte dos geotêxteis a deformação inicial a a por fluência são menores paro os de poliéster (PET) do que para os de polipropileno (PP) (BARAS, 2001).

MATICHARD et al.(1990) afirmam que o principal fator que interfere na fluência é o tipo de polímero constituinte do geossintético.

\subsubsection{Tipo de geotêxtil quanto à forma de fabricação.}

De uma outra forma, a fluência dos geotêxteis não tecidos pode ser classificada como estrutural e polimérica. A parcela de fluência estrutural ocorre logo após a aplicação do carregamento e pode ser associada ao alinhamento dos filamentos segundo a direção de tração e aos deslocamentos viscosos que ocorrem nos contatos entre filamentos. A fluência polimérica, por sua vez, é causada pelos movimentos viscosos das macromoléculas do polímero em si. Estas parcelas podem ocorrer simultaneamente no início do carregamento, mas a tendência é que, ao longo do tempo, haja uma prevalência da parcela polimérica sobre a estrutural.

Em vista disto, tem-se atribuído às estruturas das mantas um papel de destaque no fenômeno de fluência dos geossintéticos. Resultados de SHRESTHA \& BELL (1982), por exemplo, mostram uma maior sensibilidade à fluência dos geotêxteis não tecidos, em oposição aos tecidos. Já no caso dos não tecidos, foi detectada uma fluência mais acentuada para os de filamentos contínuos em comparação aos confeccionados com fibras cortadas. Essa relação entre filamentos contínuos e cortados também foi observada por COSTA (1999).

\subsubsection{Nível de carregamento.}

Quanto maior o carregamento maior serão os alongamentos causados pela fluência. SHRESTHA \& BELL (1982) demonstram essas interferências, através de ensaios, mais sensíveis para geotêxteis não tecidos de polipropileno. 
As mantas tecidas sofrem menos influência do carregamento, provavelmente devido ao alinhamento dos membros longitudinais. As mantas não tecidas acabam sofrendo um alinhamento natural em direção à carga solicitada.

A maior fluência observada para maiores carregamentos pode ser evidenciada no trabalho de COSTA (1999). A autora realizou ensaios em geotêxteis não tecidos de poliéster fabricados a partir de filamentos contínuos e de polipropileno, com fibras cortadas, Figuras 2.4 e 2.5, respectivamente.

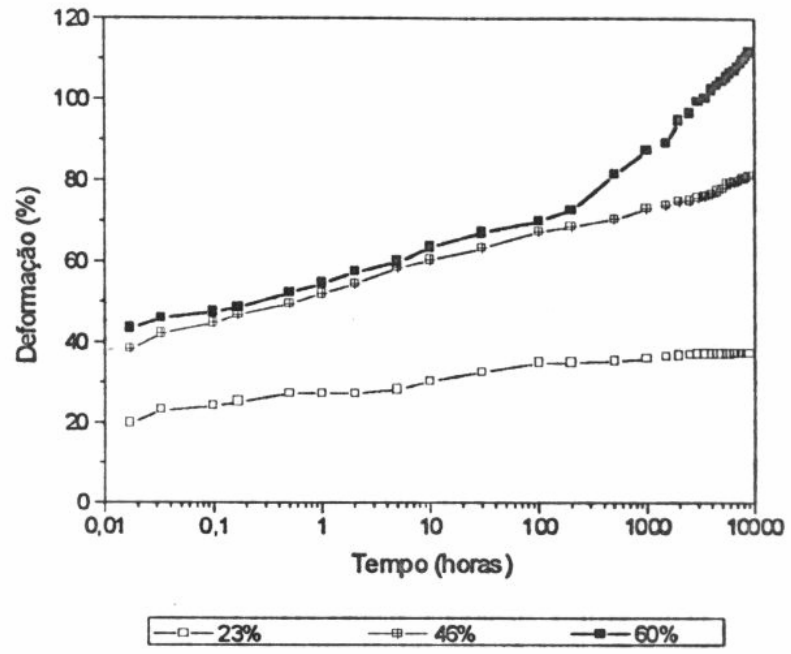

FIGURA 2.4 - Deformação total x tempo para geotêxtil não tecido de poliéster de filamentos contínuos (COSTA, 1999).

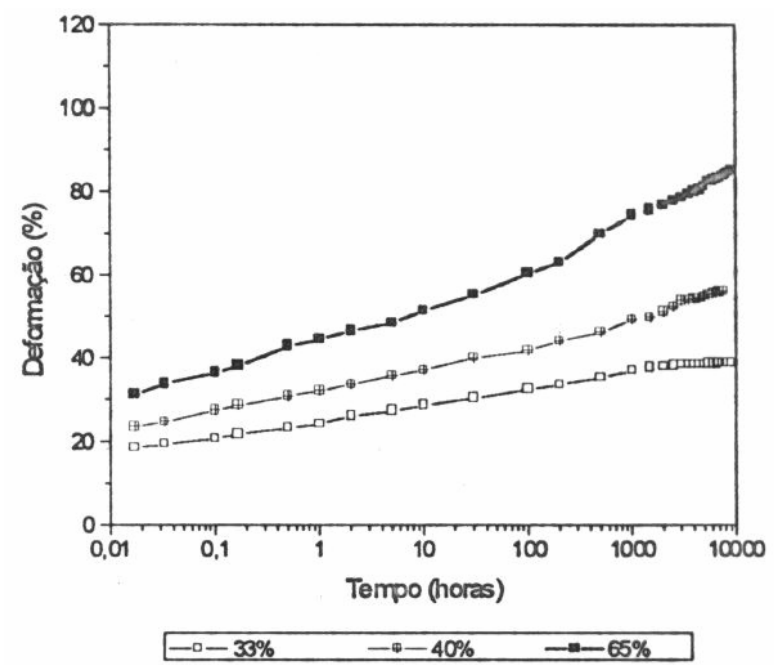

FIGURA 2.5 - Deformação total x tempo para geotêxtil não tecido do polipropileno de fibras cortadas (COSTA, 1999). 
A fluência se mostra mais intensa quanto maior for o carregamento, para ambos os tipos de geotêxteis.

\subsubsection{Presença de confinamento.}

O confinamento em geossintéticos é um fenômeno que deve ser estudado, pois, na grande maioria das vezes, estes produtos trabalham enterrados no solo sofrendo o efeito do confinamento. É de se esperar que se aumentando o confinamento reduz-se a liberdade da estrutura da manta se ajustar ao carregamento imposto. A parcela de fluência estrutural deve, portanto, diminuir.

Vários trabalhos mostram que o comportamento tensão x deformação dos geossintéticos é consideravelmente influenciado pela ação do solo envolvente, pois quanto mais o solo e reforço interagem, maior será a resistência da inclusão (RECKER \& MÜLLERROCHHOLZ, 1996). Este aumento de resistência é acompanhado por um aumento de rigidez à tração do geossintético.

McGOWN et al., 1982, elaboraram um equipamento pioneiro para avaliar a fluência confinada. Seus ensaios foram executados com dois tipos de geotêxteis não tecidos, um termoligado, composto de $67 \%$ de polipropileno e $33 \%$ de polietileno, e um outro agulhado com 100\% poliéster, Figura 2.6. Pode-se perceber da figura que ocorreu uma substancial redução nas deformações dos geotêxteis, tanto no valor inicial quanto na deformação por fluência. Este fato demonstra claramente que ensaios não confinados superestimam valores de rigidez e fluência. 

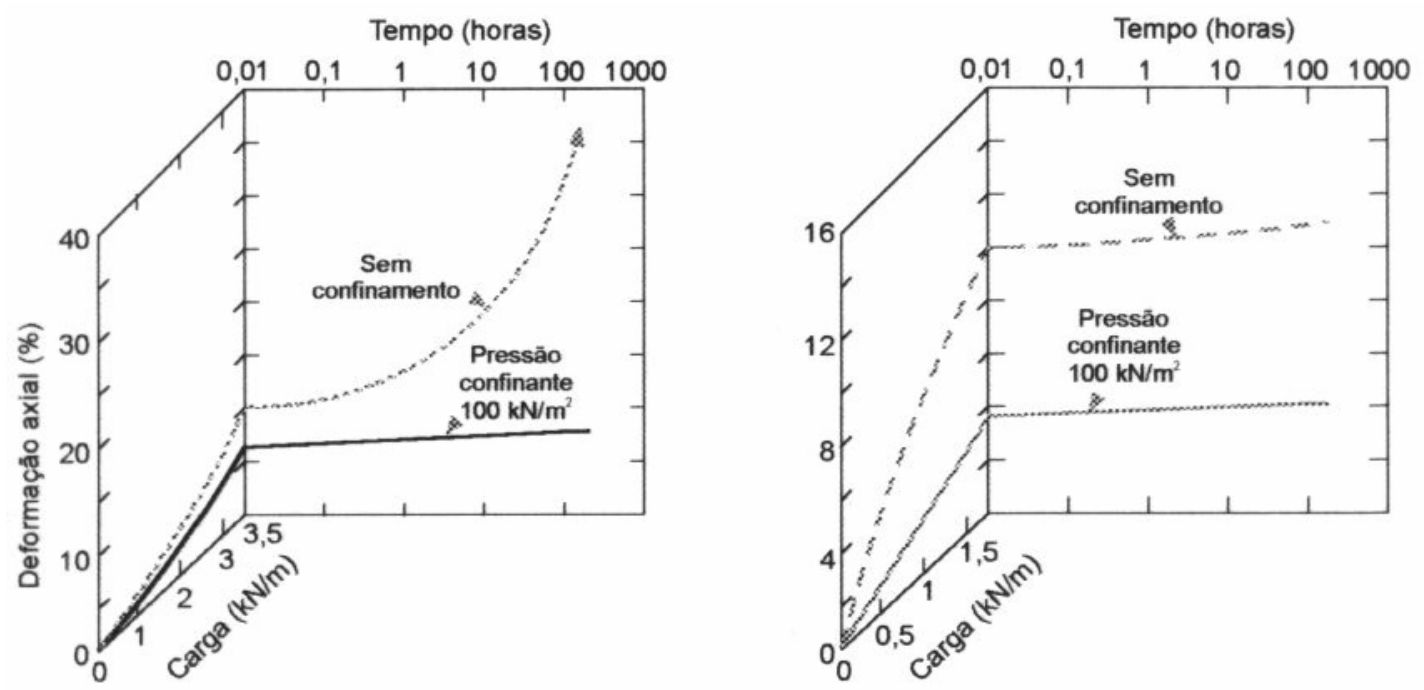

FIGURA 2.6 - Resultados de ensaios de fluência em geotêxteis não tecidos (McGOWN et al., 1982)

TUPA \& PALMEIRA (1995) publicaram resultados de ensaios confinados de geotêxteis não tecidos implantados em solos finos. Estes resultados demonstram o aumento da rigidez e a sensibilidade do material ao confinamento, principalmente para baixas deformações, Figuras 2.7 e 2.8. Os autores afirmam que tendo em vista a utilização de valores de rigidez não confinadas, usualmente presentes em catálogos de produtos de geossintéticos, as estimativas de deslocamentos de estruturas em solo reforçado podem superestimar os deslocamentos previstos para a estrutura.

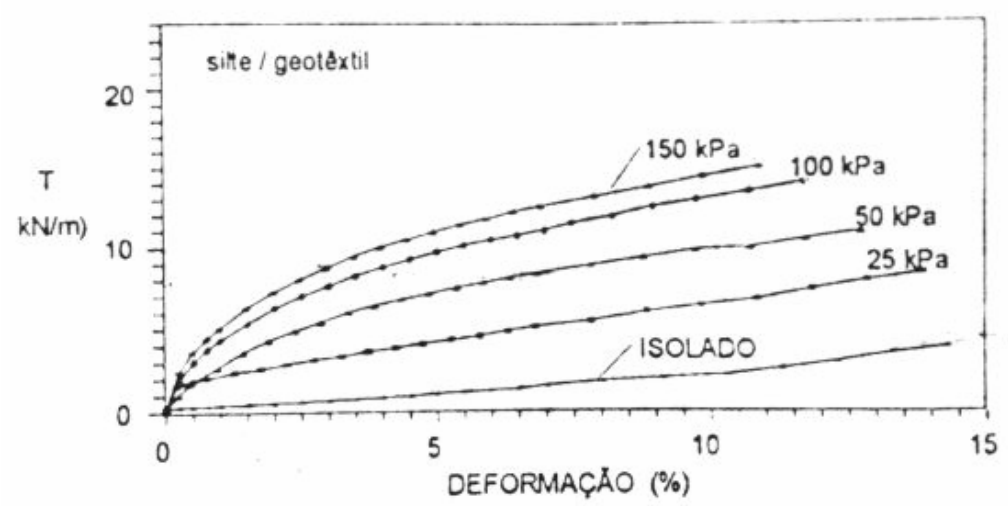

FIGURA 2.7 - Curva carga x deformação para sistema silte-geotextil (TUPA \& PALMEIRA, 1995). 


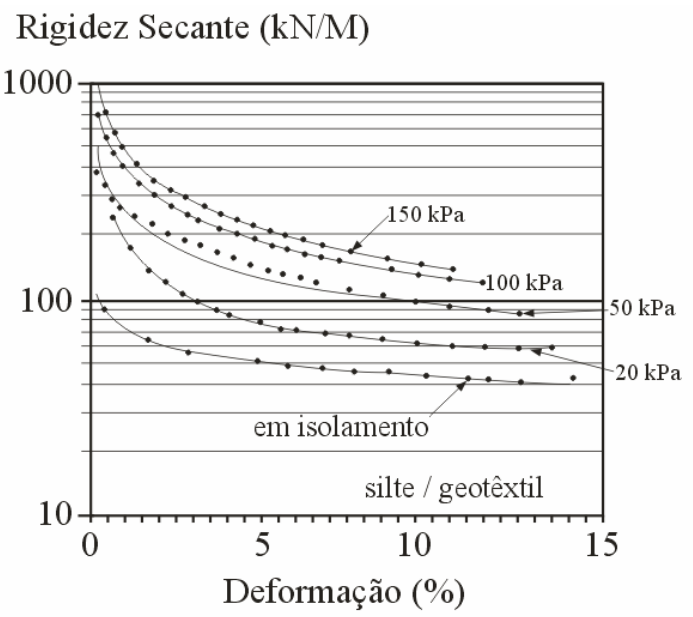

FIGURA 2.8 - Variação da rigidez secante com a deformação para o sistema silte-geotêxtil (TUPA \& PALMEIRA, 1995).

COSTA (1999) também mostra que o confinamento é capaz de reduzir as deformações totais ao longo do tempo. Seus resultados mostram que um geotêxtil de poliéster apresentou menos fluência (cerca de 10 vezes menor) do que um geotêxtil de polipropileno, para um mesmo carregamento de $40 \%$ de suas resistências à tração. O trabalho de BALLEGEER \& WU (1993) apresenta resultados de fluência confinada em que se verifica que para geotêxteis não tecidos há um substancial aumento de rigidez devido ao confinamento para baixas níveis de deformação. O comportamento dos geotêxteis tecido, por outro lado, apresenta pouca ou nenhuma influência devida ao efeito do confinamento (LEVACHER et al., 1994; KOERNER, 1994).

\subsubsection{Temperatura.}

Devido à energia cinética presente no corpo molecular, as cadeias poliméricas estão em constante movimento. As extensões destes movimentos crescem com o aumento da temperatura. Micro-estruturalmente, um corpo polimérico apresenta espaços vazios para onde se deslocam às moléculas em movimento cinético. Quando uma molécula se desloca para um espaço vazio ela deixa o seu espaço anterior para que uma outra possa se movimentar. O processo de movimentação é contínuo e depende, portanto, da existência dos espaços livres e da velocidade de movimentação das moléculas. O termo volume livre é 
utilizado em engenharia polimérica para descrever o volume total ocupado por estes vazios em um corpo polimérico. Quanto maior o volume livre, maior é a possibilidade das moléculas se movimentarem no interior da massa. Sua importância relaciona-se também com o coeficiente de expansão termal, que representa primariamente a criação de um volume livre adicional com aumentos da temperatura. A troca de posição espacial das moléculas cresce com aumentos da temperatura pela expansão termal e pelo aumento da energia de ativação das moléculas.

A partir deste modelo de comportamento, é possível estabelecer que as deformações viscosas, que ocorrem devido a estes movimentos moleculares no volume livre do corpo, crescem com o aumento da temperatura. Além disto, admitindo-se que este crescimento segue uma lei de viscosidade linear, pode-se se afirmar que existe uma proporcionalidade linear entre as deformações e o aumento da temperatura. Finalmente, se aumentos da temperatura provocam uma aceleração das deformações pelo aumento da energia de ativação, é lícito supor que estes aumentos podem ser entendidos como uma aceleração do tempo. Reside nesta asserção a base física dos ensaios de fluência acelerados com os aumentos da temperatura, que serão detalhados mais a frente neste capítulo.

Há duas temperaturas importantes que regem os movimentos moleculares e, portanto, o comportamento visco-elástico dos materiais poliméricos. A primeira delas é denominada temperatura de fusão (Tm) e é característica das zonas cristalinas. A segunda, denominada temperatura de transição vítrea (Tg), pode ser descrita como um ponto ou pequena região na escala de temperatura onde o coeficiente de expansão termal sofre uma descontinuidade, caracterizando a passagem do estado físico sólido para um outro conhecido como de mobilidade (FERRY, 1980). Esta temperatura de transição, características das zonas amorfas dos polímeros, corresponde a uma mudança na inclinação da reta que define volume específico vs. temperatura, como ilustrado na Figura 2.9. Nesta figura, volume específico refere-se ao volume do material em uma dada temperatura dividido pelo seu volume na temperatura de transição vítrea. 


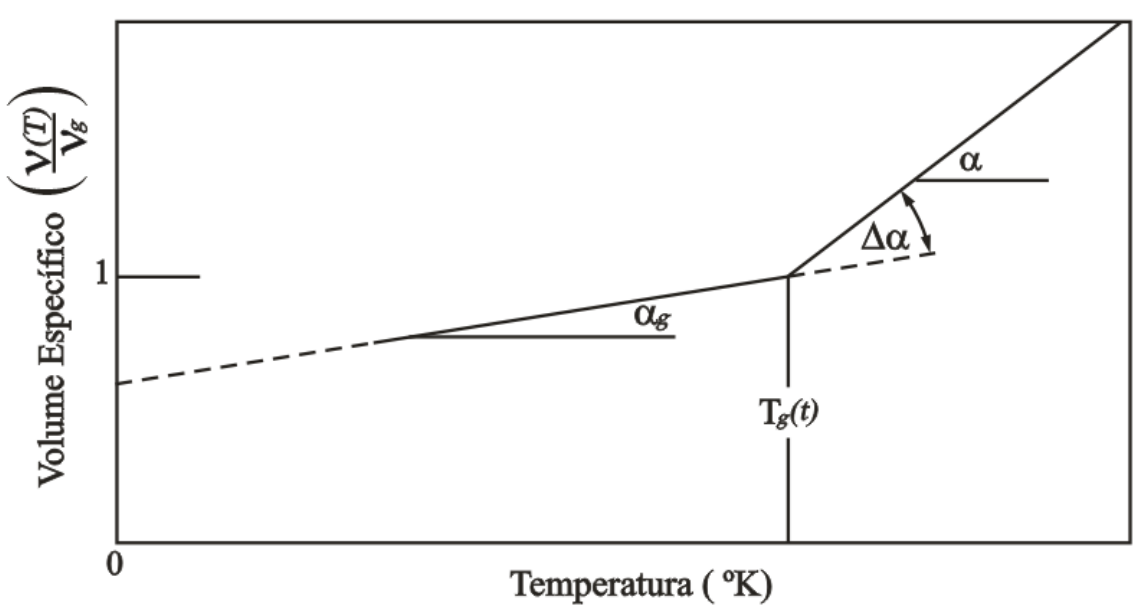

FIGURA 2.9 - Esquema da variação do volume específico vs. Temperatura (relativo ao volume específico em Tg). (modificado de FERRY, 1980).

Ainda em relação à temperatura de transição vítrea (Tg), nota-se que abaixo da Tg os movimentos intermoleculares das zonas amorfas se reduzem drasticamente à medida que a temperatura diminui e considera-se que haja um congelamento das atividades. O material torna-se rígido e apresenta um comportamento tensão versus deformação do tipo frágil. Acima da Tg estes movimentos se acentuam, o material torna-se mais deformável com curva carga versus deformação do tipo plástico.

Devido à aceleração no comportamento viscoelástico dos polímeros em altas temperaturas, atualmente, tem sido cada vez mais estudado a utilização desse artifício em ensaios de fluência acelerados. Esses tipos de ensaios serão abordados posteriormente neste trabalho.

\subsection{Caracterização da fluência.}

A caracterização da fluência é feita, normalmente, a partir de ensaios de laboratório, principalmente os ensaios não confinados. Esses resultados servem para incorporar, nos cálculos dos reforços, a ação das cargas constantes nas deformações das fibras dos geossintéticos e nas relaxações por tensão, que podem afetar a estrutura reforçada por excesso de deformação ou falha no sistema. 
KOERNER et al. (1988) afirmam que existem três maneiras de se avaliar o comportamento quanto à fluência:

- Testes de laboratório: os testes podem ser confinados, não confinados e não confinados acelerados. Eles apresentam problemas como o efeito escala, tempo requerido para a execução dos ensaios e os problemas de confinamento.

- Projeções analíticas: SHRESTHA \& BELL (1982) apresentam varias alternativas como "teoria das taxas", modelos reológicos e modelos empíricos. Essas projeções requerem dados laboratoriais como parâmetros iniciais dos cálculos.

- Instrumentação e acompanhamento de muros reforçados: esse tipo de avaliação traz a interação solo/inclusão mostrando menor fluência do que o normalmente previsto.

Nesta data, a norma brasileira para ensaios de fluência já foi aprovada e está por vias de ser publicada pela ABNT. Em vista disto, os ensaios executados pelo Laboratório de Geossintéticos baseiam-se em normas de outros países como a da AMERICAN SOCIETY FOR TESTING AND MATERIALS - ASTM D5262 (1992) ou a da INTERNATIONAL ORGANIZATION FOR STANDARTDIZATION - ISO 13431.

Os ensaios, segundo estas normas, são feitos em corpos de prova de $200 \mathrm{~mm}$ de largura por 100mm de comprimento (faixa larga), submetidos a carregamentos constantes (porcentagem da resistência à tração), registrando-se as deformações em tempos préestabelecidos. Os ensaios podem ser curtos (1.000 horas) ou de longa duração (acima de 10.000 horas).

Os resultados dos ensaios são mostrados de várias formas, cada uma com sua vantagem. A forma mais comum é a curva de deformação (\%) versus tempo, em escala logarítmica. Outra forma de representação são as curvas isócronas, que mostra a variação das deformações com o carregamento, para um tempo pré-determinado. Esse tipo de curva é interessante, pois permite visualizar o comportamento do geossintético para um determinado tempo de vida da obra. Para isto são necessários os conhecimentos de algumas curvas de fluência. Ao definir o tempo, se obtém uma curva isócrona através de pares de 
pontos de cada uma das curvas disponíveis (deformação versus carga aplicada). Esse tipo de curva é mostrado na Figura 2.10.
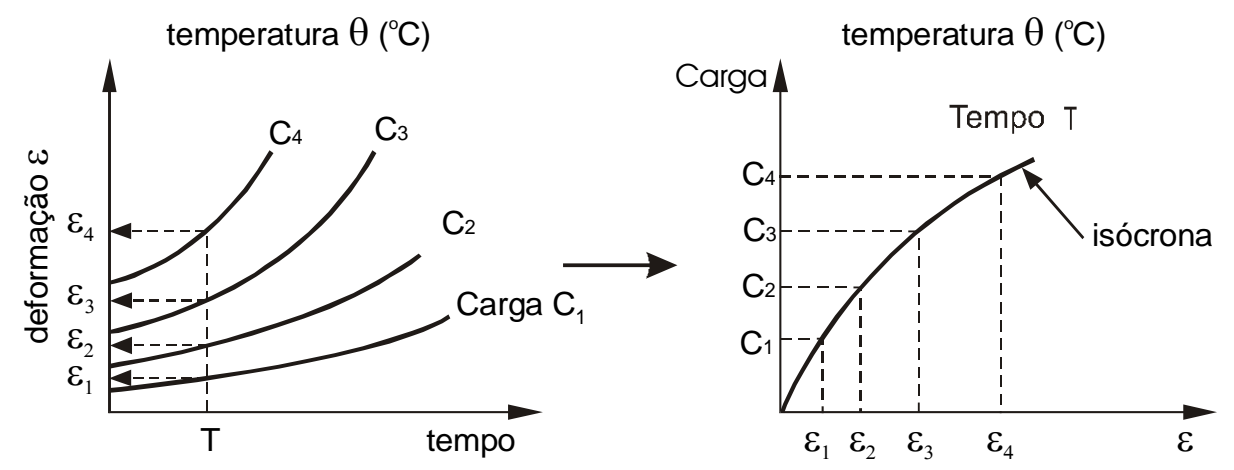

FIGURA 2.10 - Obtenção das curvas isócronas (BARAS, 2001).

Esses tipos de curvas são fundamentais para projetos em solos reforçados, pois a partir delas podemos quantificar as deformações ao longo do tempo destes materiais, e conseqüentemente obter parâmetros para o a análise de estado limite de utilização.

Para projetos onde o importante é o estudo do estado limite último, obras de solo reforçadas com geotêxteis com elevados tempos de vida útil, exigem-se uma abordagem diferente do estudo da fluência. Essa abordagem baseia-se em determinar o tempo de ocorrência de ruptura por fluência.

Os ensaios para verificação de ruptura por fluência, quando representam a carga versus tempo em escala logarítmica, apresentam comportamento linear. Com isso, é comum a extrapolação dos dados para obtenção do tempo de ruptura para carregamentos mais baixos. Na Figura 2.11 pode-se ver o esquema de uma curva de ruptura por fluência de onde é possível obter a resistência à tração de referência para um geossintético ao final de sua vida útil. 


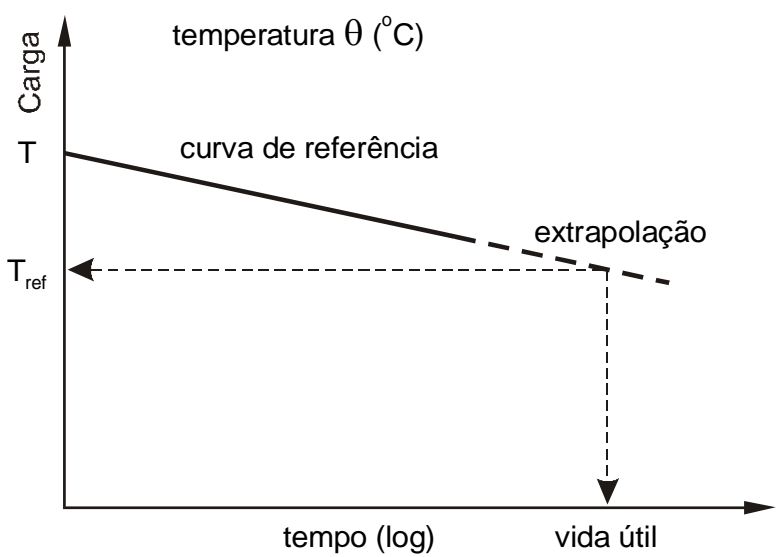

FIGURA 2.11 - Obtenção da resistência à tração de um geotêxtil a partir da curva de ruptura por fluência (BARAS, 2001).

É importante salientar, que na pratica, não são aconselháveis extrapolações das curvas de fluência em mais de um ciclo logaritmo (JEWELL \& GREENWOOD, 1988). Disto decorre que para se avaliar o efeito d fluência em uma obra cujo período de vida útil é de 100 anos seriam necessários resultados de, pelo menos, 10 anos de observação. Considerando este longo tempo de ensaios, muitos materiais comercializados rotineiramente no Brasil não dispõem de seus resultados de ensaios de fluência. Portanto, qualquer tentativa de se acelerar a determinação da fluência em geossintéticos é de grande valia. Neste contexto, alguns pesquisadores têm utilizado recursos experimentais e de tratamento de resultados já consagrados na engenharia de polímeros, para acelerar os tempos de observação dos ensaios de fluência.

Com isso, aproximações cinéticas e termodinâmicas têm sido utilizadas para medir e explicar as mudanças de comportamento nas propriedades dos polímeros. Admite-se em geral que estes materiais apresentam comportamento reológico de viscoelasticidade linear, em que as tensões podem ser descritas como uma função linear da taxa das deformações que ocorrem ao longo do tempo. Isto permite que se utilize o princípio de superposição de Boltzman, segundo o qual, a resposta de fluência de um material é função do histórico de carregamento aplicado, e cada estágio de carregamento pode ser tratado como evento independente. A resposta total de fluência, admitida a superposição de efeitos, é a soma das respostas individuais dos eventos independentes. 
Uma maneira de se extrapolar os dados é a utilização de modelos reológicos ou através de equações como a de Arrhenius e Williams-Landel-Ferry.

\subsubsection{Modelos reológicos.}

Existem vários modelos reológicos como os modelos viscoelásticos de Boltzmann e o de Burger (MSOUTI et al., 1997).

Os modelos reológicos de SAWICKI \& KAZIMIEROWICZ-FRANKOWSKA (1998) prevêem não só as deformações ao longo do tempo com carregamentos constantes, mas também a parcela recuperável após o descarregamento, pois os dois modelos são apresentados para casos de carregamento seguidos de descarregamento. Estes são apresentados nas Figuras 2.12 e 2.13.

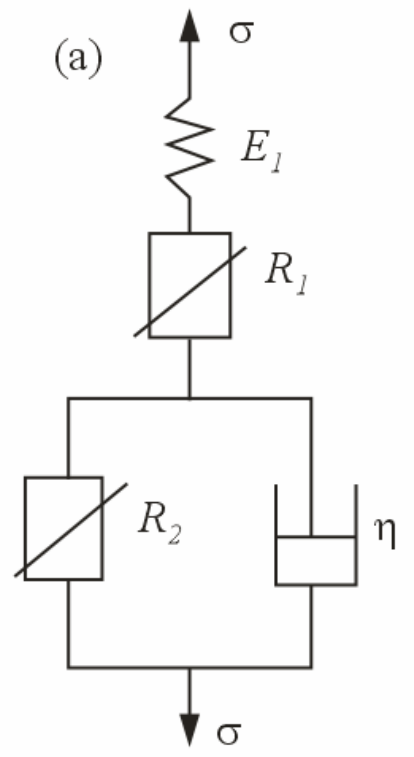

(b)
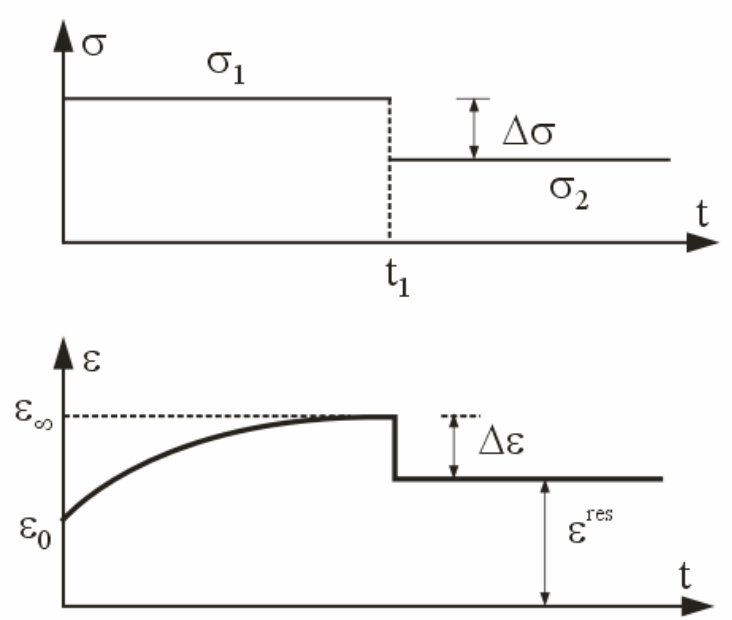

FIGURA 2.12 - (a) Primeiro modelo reológico (b) Curva de fluência com descarregamento parcial (SAWICKI \& KAZIMIEROWICZ-FRANKOWSKA, 1998). 
(a)

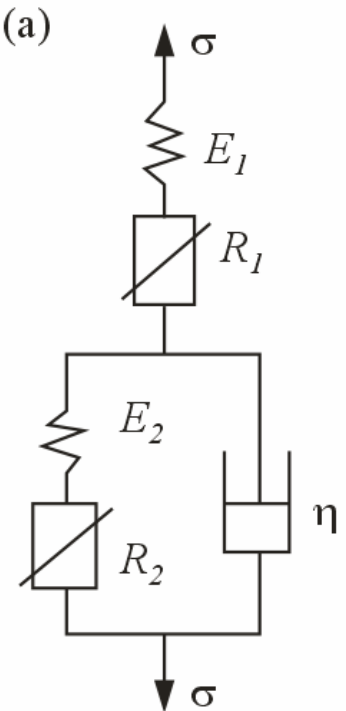

(b)
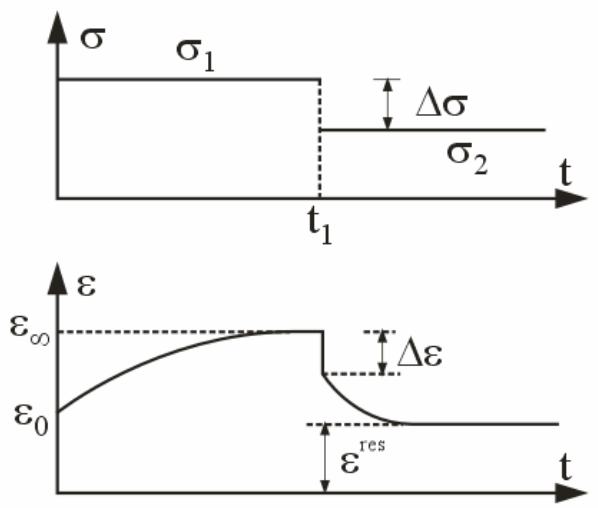

FIGURA 2.13 - (a) Segundo modelo reológico (b) Curva de fluência com descarregamento parcial (SAWICKI \& KAZIMIEROWICZ-FRANKOWSKA, 1998).

As deformações totais são dadas pelas seguintes expressões, respectivamente, para cada modelo:

$$
\begin{aligned}
& \varepsilon(t)=\sigma \cdot\left(\frac{1}{E_{1}}+\frac{1}{R_{1}}+\left(\frac{1}{R_{2}} \cdot\left(1-e^{\frac{-R_{2} \cdot t}{\eta}}\right)\right)\right) \\
& \varepsilon(t)=\sigma \cdot\left(\frac{1}{E_{1}}+\frac{1}{R_{1}}+\left(\left(\frac{E_{2}+R_{2}}{E_{2} \cdot R_{2}}\right) \cdot\left(1-e^{\frac{-\left(\frac{E_{2} \cdot R_{2}}{E_{2}+R_{2}}\right) \cdot t}{\eta}}\right)\right)\right)
\end{aligned}
$$

Quando:

$$
R_{i}=\frac{\sigma_{i}}{\varepsilon_{i}}
$$

Para:

$$
\begin{aligned}
& \sigma \text {-deformação total aplicada no sistema; } \\
& E_{i} \text { - módulo de elasticidade do elemento; } \\
& \sigma_{i} \text { - tensão no elemento } i \\
& \varepsilon_{i} \text { - deformação no elemento } ; \\
& \eta \text { - vis cos idade do material; }
\end{aligned}
$$


O primeiro modelo define quatro parâmetros e é aplicado para baixos níveis de tensão. Já o segundo modelo define cinco parâmetros e é recomendado para altos níveis de tensão.

KOERNER et al.(2001) apresenta outro modelo reológico, Figura 2.14, chamado de modelo de Kelvin-Chain, onde são utilizados elementos associados na extrapolação de dados de fluência em GCL’s.

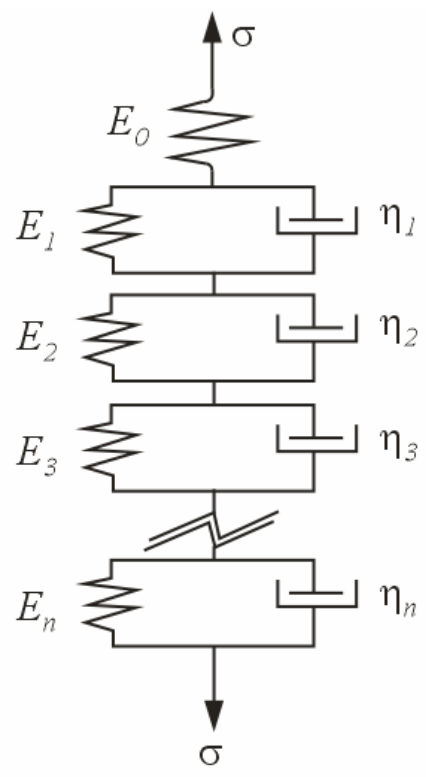

FIGURA 2.14 - Modelo reológico de Kelvin-Chain (KOERNER et al., 2001).

Para deformação total dada pela seguinte expressão:

$$
\varepsilon \quad(t)=\sigma \cdot\left(\varepsilon_{0}+\sum_{i=1}^{n} \frac{1}{E_{i}} \cdot\left(1-e^{\frac{E_{i} \cdot t}{\eta_{i}}}\right)\right)
$$

Para:

$\sigma$ - deformação aplicada no sistema;

$E_{0}$ - módulo de elasticidade do elemento isolado;

$E_{i}$ - módulo de elasticidade do elemento;

$\eta_{i}$ - vis cos idade do material; 


\subsubsection{Extrapolações com as equações de Arrhenius e Williams-Landel-Ferry.}

As previsões ou extrapolações das deformações por fluência em função da temperatura podem ser tratadas através de equações como a de Arrhenius ou a de William-Landel-Ferry (WLF). A primeira foi concebida para reger o estudo do movimento dos gases (cinética). É utilizada também para exprimir transformações físicas e reações químicas que dependem da temperatura (SEGRESTIN and JAILLOUX, 1988). A equação pode também exprimir uma relação entre a temperatura e a deformação de fluência, $\varepsilon$, como:

$$
\varepsilon=A_{0} \cdot e^{\left(\frac{-E}{R \cdot T}\right)}
$$

Onde:

$\varepsilon$ - deformação por fluência;

Ao - constate que depende do material e do fenômeno envolvido;

E - energia de ativação (cal/mol);

$\mathrm{R}$ - constante de Bolzmann (2cal/mol. $\left.{ }^{\circ} \mathrm{K}\right)$;

$\mathrm{T}$ - temperatura absoluta $\left({ }^{\circ} \mathrm{K}\right)$.

A equação (2.6) mostra que a taxa de deformação por fluência aumenta com a temperatura e com o decréscimo da energia de ativação, sendo todos os outros fatores mantidos constantes. A dificuldade do uso desta equação reside na obtenção da energia de ativação, visto que nos ensaios de fluência a taxa de deformação se altera com o tempo. Segundo SEYMOUR e CARRAHER (1984) a equação de Arrhenius não é particularmente útil para temperaturas superiores a $\mathrm{Tg}+100^{\circ} \mathrm{K}$. Para essas faixas de temperatura torna-se mais interessante o uso da equação de WLF.

A equação WLF exprime uma translação do tempo em função da temperatura, através de um fator de aceleração ou de retardamento. Neste processo, curvas de fluência obtidas para temperatura superiores a um valor de referência são transladadas ao longo do eixo de tempo de forma a se obter uma única curva, a curva mestra da temperatura de referência, pelo alinhamento das várias curvas. O fator de translação, $\alpha_{t}$, pode ser expresso da seguinte forma: 


$$
\log \left(\alpha_{t}\right)=\frac{-C_{1} \cdot\left(T-T_{0}\right)}{\left(C_{2}+T-T_{0}\right)}
$$

Onde:

T - temperatura do ensaio;

To - temperatura de referência adotada;

C1 e C2 - constantes que dependem do tipo de material utilizado, onde C1 é adimensional e C2 tem a unidade da temperatura adotada.

Alternativamente, o alinhamento das curvas pode ser feito graficamente, com métodos de superposição tempo-temperatura (TTS). Segundo este processo, mantém-se a curva de fluência obtida para a temperatura de referência na sua posição original e desloca-se o conjunto de curvas de temperatura superiores até o alinhamento. Esse processo é base dos ensaios acelerados de fluência, abordados a seguir.

\subsection{Ensaios acelerados de fluência.}

Os ensaios acelerados podem ser executados com os mesmos instrumentos dos ensaios convencionais, mas em um ambiente de temperatura controlada. Descrições de equipamentos utilizados para a execução deste tipo de ensaios podem ser encontradas, por exemplo, em FARRAG e SHIRAZI (1997) e BARAS (2001).

Há basicamente dois procedimentos experimentais para a execução desses ensaios, o convencional e o Stepped Isothermal Method (SIM).

\subsubsection{Ensaios acelerados de fluência do tipo convencional.}

No método convencional, são realizados vários ensaios de fluência em corpos de provas distintos sob mesmo carregamento em diferentes temperaturas. Este tipo de procedimento apresenta o inconveniente da variabilidade nas amostras.

Os equipamentos utilizados para este tipo de ensaio podem ser os mesmos dos utilizados para a fluência não confinada, acrescentando-se um ambiente de temperatura controlada. Esse mecanismo tem que contar com um sistema de carregamento, garras para a 
fixação do geossintético, mecanismo de controle de temperatura e algum sistema para equipamento para leitura das deformações.

FARRAG \& SHIRAZI (1997) desenvolveram um equipamento pioneiro, uma espécie de forno, onde a configuração eliminou a possibilidade da temperatura afetar os instrumentos de medida. O carregamento foi controlado por células de carga e as deformações (deslocamentos) através de LVDT’s. Os instrumentos foram conectados a um computador responsável pelo monitoramento e aquisição de dados em intervalos de tempo pré-estabelecidos.

A seguir é mostrado um ensaio realizado por FARRAG \& SHIRAZI (1997) onde, através de ensaios com temperaturas elevadas e utilizando-se a técnica de superposição tempo x temperatura (STT), obteve-se a curva acelerada de fluência. A Figura 2.15 mostra o resultado do ensaio de fluência com carregamento de $16 \mathrm{kN} / \mathrm{m}$ aplicado à geogrelha do tipo PEAD (polietileno de alta densidade), sob cinco diferentes temperaturas: 75, 100, 120 e $140^{\circ} \mathrm{F}\left(24,38,49\right.$ e $\left.60^{\circ} \mathrm{C}\right)$.

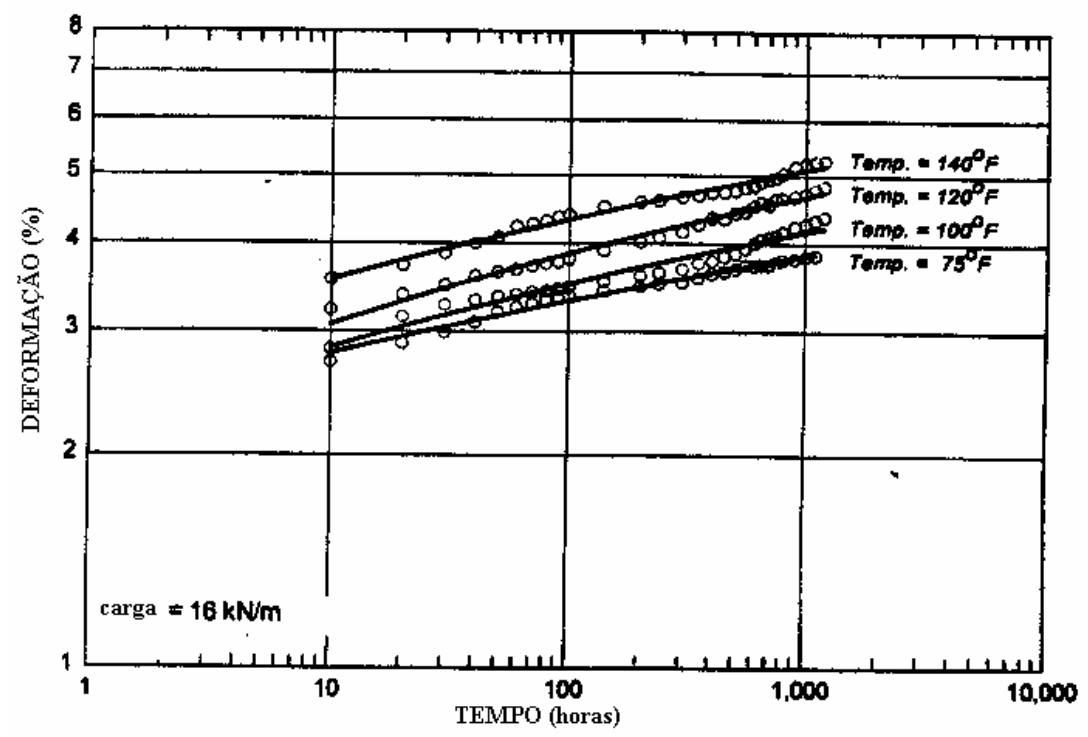

FIGURA 2.15 - Resultados de ensaios de fluência em geogrelha de PEAD em 4 diferentes temperaturas (FARRAG \& SHIRAZI, 1997).

Através de translações horizontais das curvas obteve-se a curva acelerada de fluência, curva mestra, que foi comparada com ensaio de 10.000 horas de fluência não confinada (Figura 2.16). 


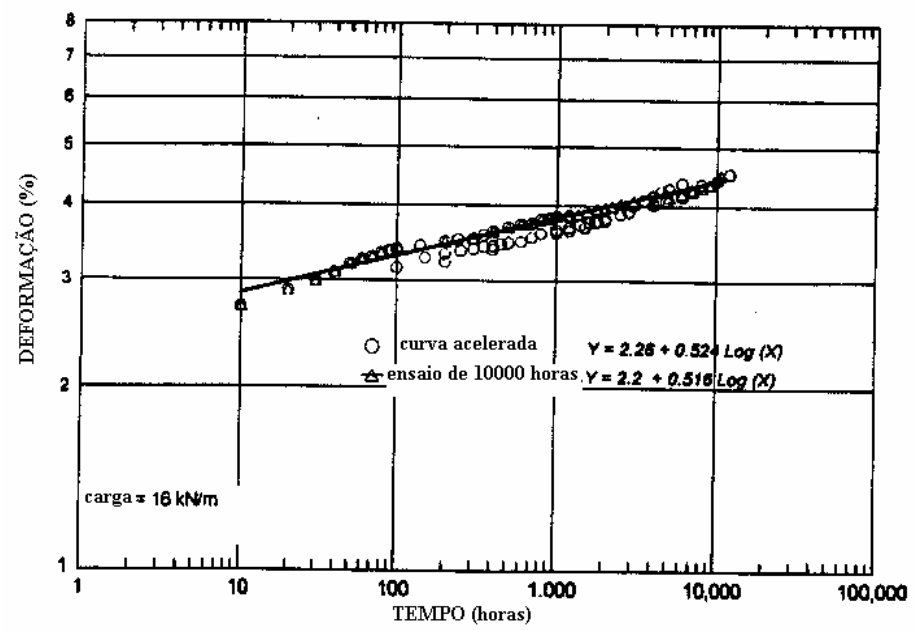

FIGURA 2.16 - Curva de fluência obtida para ensaio acelerado convencional (FARRAG, 1998).

O ensaio foi repetido para carregamentos de 13, 22 e $28 \mathrm{kN} / \mathrm{m}$. Verificou-se a validade do ensaio acelerado para prever a fluência quando se aplicam baixos carregamentos. Para ensaios com carregamentos elevaos, acima de 40\% de resistência à tração da geogrelha, no caso a $28 \mathrm{kN} / \mathrm{m}$, observou-se que as curvas não apresentam similaridade, invalidando o método para estes níveis de carregamentos (Figura 17).

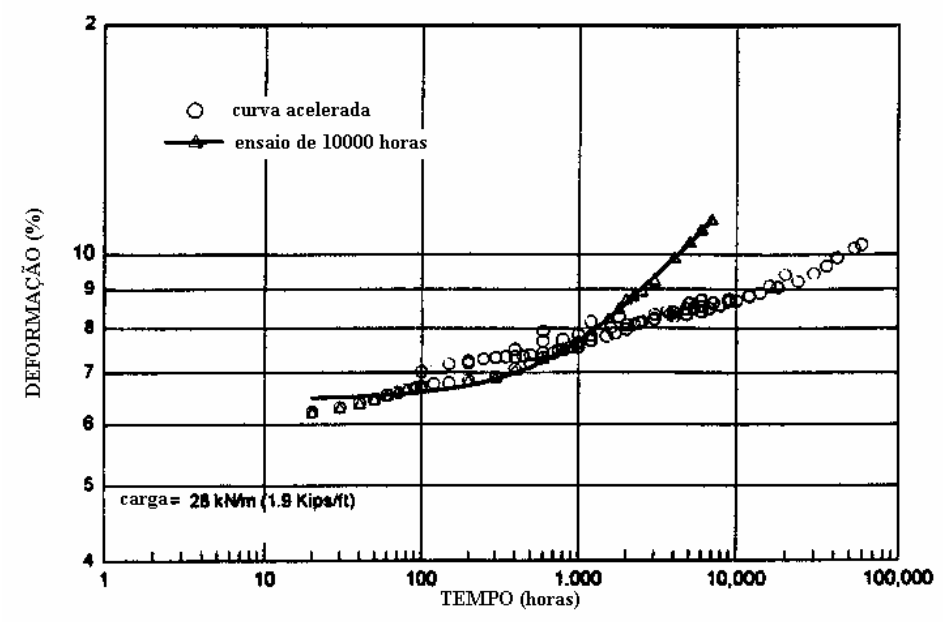

FIGURA 2.17 - Curva de fluência obtida para ensaio acelerado convencional (FARRAG, 1998). 
FARRAG (1998) ainda obteve graficamente os fatores de translação, pela equação de William-Landel-Ferry (WLF) e graficamente, como mostrados nas Figuras 2.18 e 2.19 respectivamente.

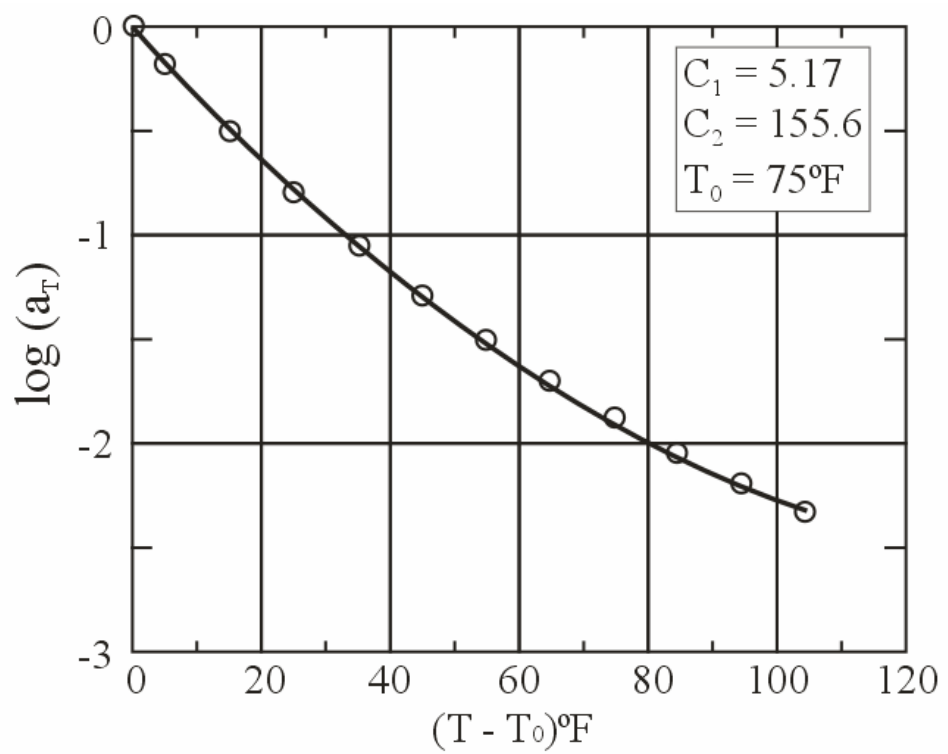

FIGURA 2.18 - Fatores de translação calculados pela equação WLF (FARRAG, 1998).

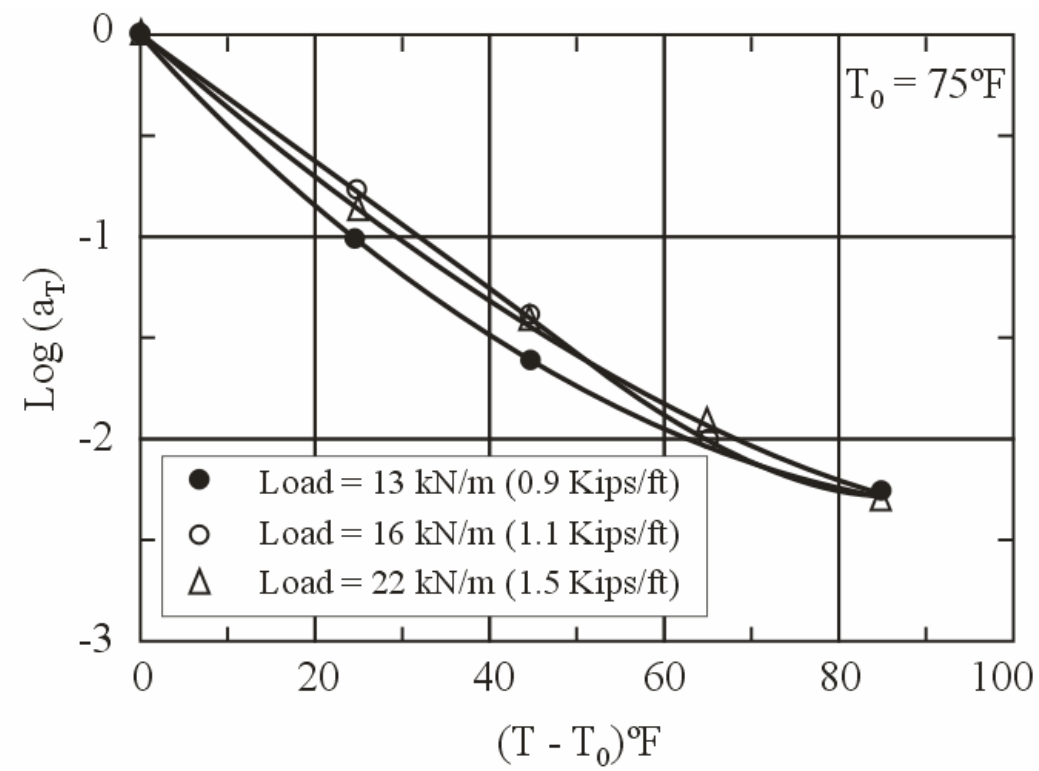

FIGURA 2.19 - Fatores de translação obtidos graficamente (FARRAG, 1998).

O processo experimental, denominado ensaios convencionais de fluência acelerados, mostrou-se satisfatório, mas com o inconveniente de utilizar vários corpos de prova. Isto pode aumentar a possibilidade de variabilidade nos resultados. 


\subsubsection{Ensaios acelerados de fluência do tipo “Stepped Isothermal Method (SIM)”.}

O processo SIM foi idealizado por THORTON et al. (1998) para minimizar problemas de variabilidade do material, pois é executado com apenas um corpo de prova. Para aplicação deste método deve-se admitir que o material apresenta comportamento de viscoelasticidade linear, quando é possível aplicar princípio de superposição de Boltzmann, onde o evento independente é a temperatura. Segundo os autores, o SIM, para superposição tempo versus temperatura, reduz as incertezas dos fatores de translação usados para construir as curvas de fluência aceleradas. Com esse método podem-se construir curvas com mais de 100 anos de resposta, porém a adoção de temperaturas ou tempos de parada inadequados resultam em curvas curtas ou ineficientes. A escolha errada da temperatura pode levar os corpos de prova a rupturas pré-maturas.

Os fatores de translação para a fluência revelam ser diretamente dependente da temperatura e inversamente da tensão aplicada.

A técnica do SIM, como mencionado, baseia-se no princípio de Boltzman, porém em vez de se variar o carregamento, são alteradas as temperaturas em vários estágios. Este processo também utiliza equipamentos semelhantes aos convencionais, mas com ambiente de temperatura controlada.

Para realização destes ensaios podemos utilizar o mesmo equipamento do ensaio acelerado do tipo convencional.

Os passos para a obtenção da curva de fluência acelerada pelo método SIM são mostrados a seguir (THORNTON et al., 1998): 
- $1{ }^{\circ}$ passo: Plotar os dados de deformação por fluência e módulo de fluência em função do tempo, em escala linear, para identificar os tempos de início virtual dos estágios (mudança de temperatura);

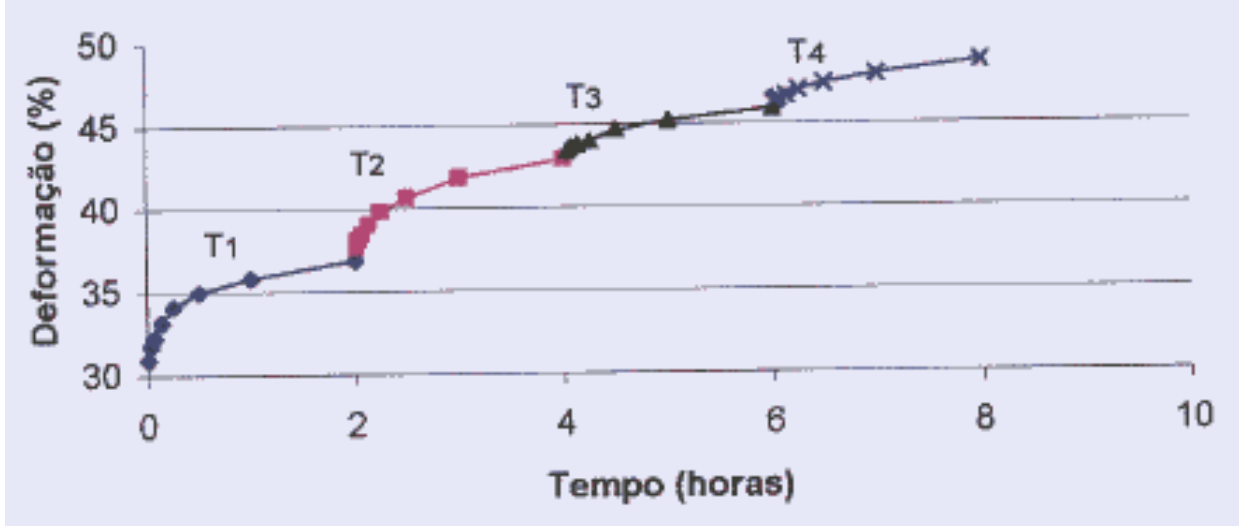

FIGURA $2.20-1^{\circ}$ passo do método SIM (BARAS, 2001).

- $\quad 2^{\circ}$ passo: Usando os módulos de fluência e os parâmetros de interesse, plotar estes parâmetros em escala logarítmica (mudança do eixo tempo para escala logarítmica);

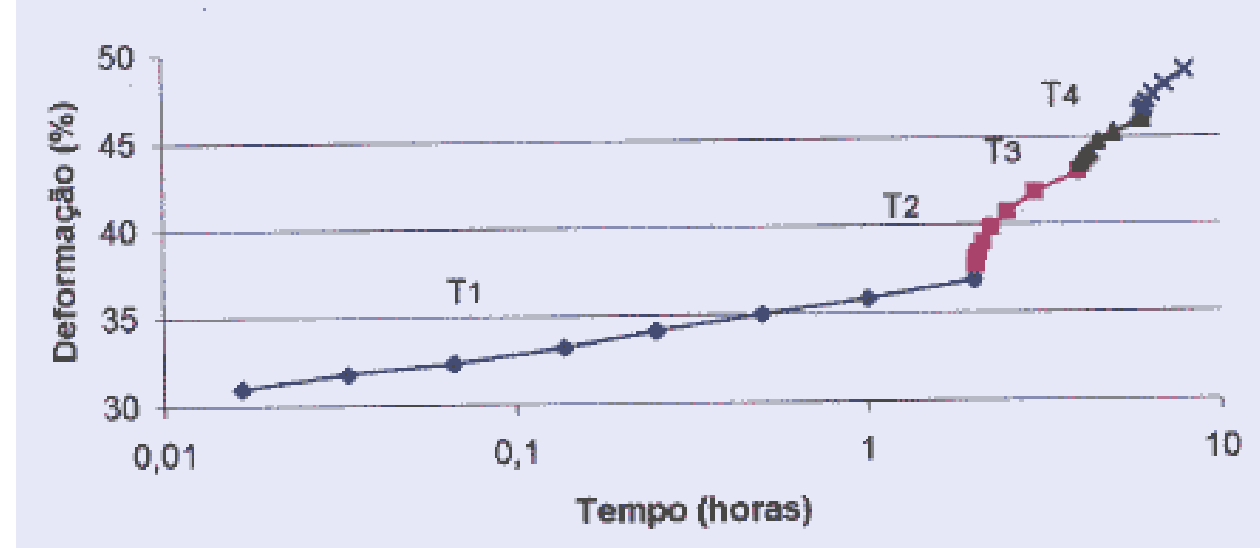

FIGURA $2.21-2^{\circ}$ passo do método SIM (BARAS, 2001). 
- $\quad 3^{\circ}$ passo: Mudar a escala de tempo para cada trecho do ensaio para plotá-los em escala logarítmica, de modo a obter seus tempos virtuais de inicio. Isso é alcançado quando a inclinação inicial do novo trecho é igual ao do final de trecho anterior.

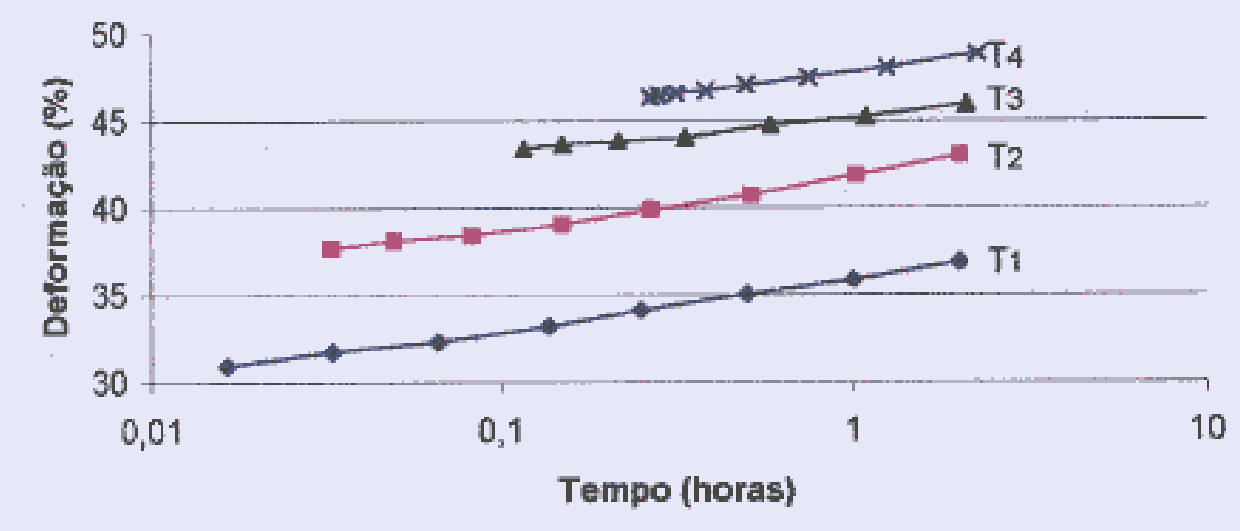

FIGURA 2.22 - $3^{\circ}$ passo do método SIM (BARAS, 2001).

- $4^{\circ}$ passo: Remover os efeitos da expansão térmica através de translação vertical;

- $5^{\circ}$ passo: Através de translações horizontais obter a exata justaposição dos trechos, obtendo-se a curva de fluência acelerada.

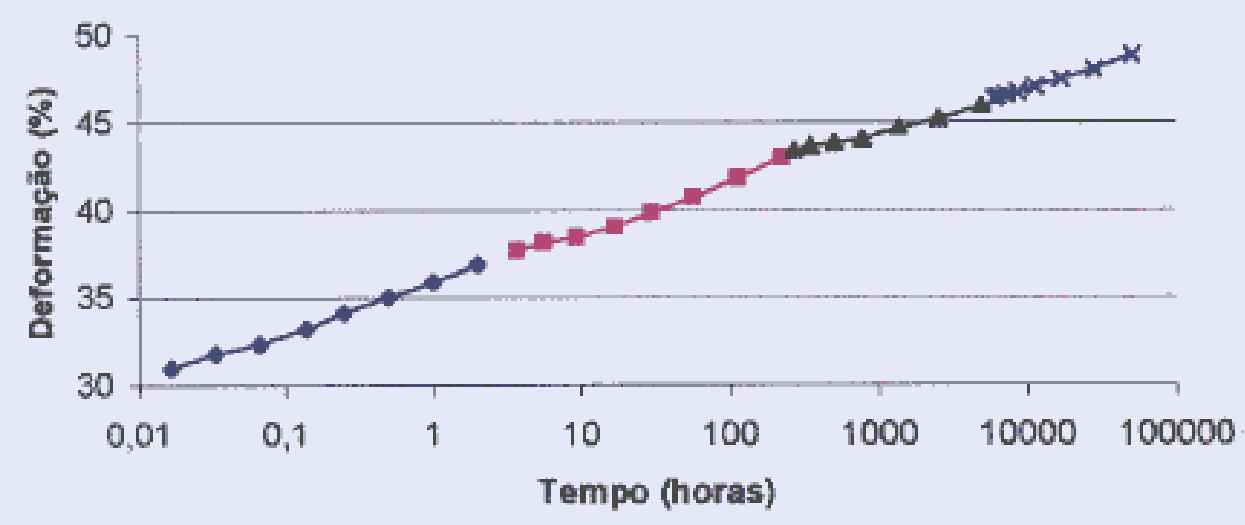

FIGURA $2.23-4^{\circ}$ e $5^{\circ}$ passos do método SIM (BARAS, 2001). 


\subsubsection{Ensaios acelerados de ruptura por fluência.}

Normalmente os ensaios de ruptura são realizados com corpos de prova submetidos a altos carregamentos, para que se obtenham as rupturas em tempos relativamente curtos. Esses valores são então extrapolados, como visto anteriormente (Figura 2.11). Como para ensaios com baixos carregamentos a ruptura pode demorar anos para acontecer, os ensaios acelerados acabam sendo muito úteis pra esta finalidade.

GREENWOOD \& VOSKAMP (2000) realizaram ensaios acelerados de fluência do tipo convencional, e obtiveram a curva de ruptura com uma combinação de ensaios acelerados convencionais e ensaios convencionais, conforme mostra a Figura 2.24.

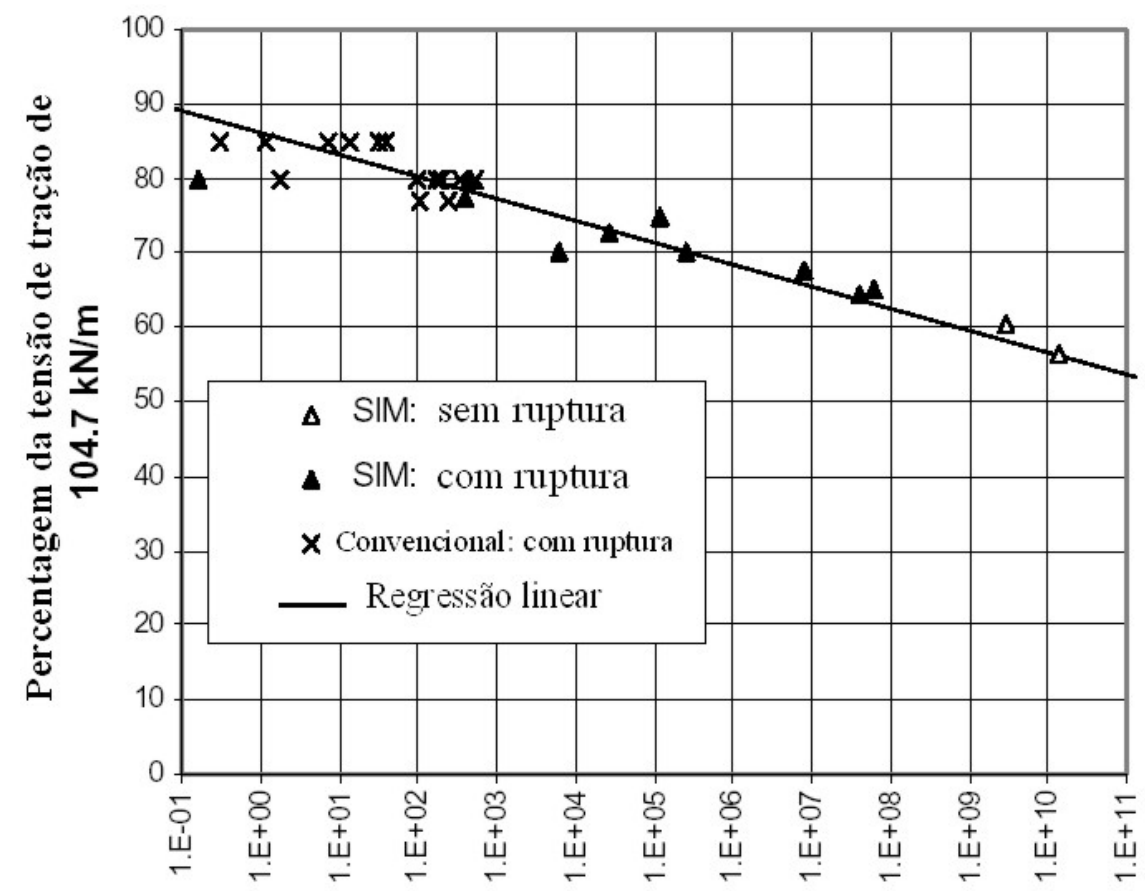

Tempo(h)

FIGURA 2.24 - Curva de ruptura por fluência obtidas com vários corpos de prova (GREENWOOD \& VOSKAMP, 2000).

Os autores salientam que o problema deste método é a variabilidade que os geossintético apresentam em amostras nominalmente idênticas. 
O método SIM pode ser utilizado para auxiliar a obtenção da curva de ruptura. Pode-se obter um alinhamento dos pontos obtidos através dos ensaios convencionais de ruptura, e dos pontos obtidos pelo método SIM.

Com isso minimizam-se as incertezas das extrapolações para carregamentos mais baixos. 


\section{CAPÍTULO 3}

\section{MATERIAIS E MÉTODOS}

Neste capítulo são mostrados os instrumentais utilizados para realizar os ensaios de fluência, os materiais ensaiados e os procedimentos de execução dos ensaios.

\subsection{Materiais utilizados}

Foram ensaiados dois geotêxteis não tecidos, de fibras curtas e agulhados, A e B, cujas caracterizações física e mecânica foram feitas através de ensaios prescritos pela ASSOCIAÇÃO BRASILEIRA DE NORMAS TÉCNICAS - ABNT. A Tabela 3.1 descreve os tipos de materiais utilizados, e a Tabela 3.2 suas gramaturas e resistências à tração.

TABELA 3.1 - Características de fabricação dos geotêxteis ensaiados.

\begin{tabular}{|c|c|c|}
\hline $\begin{array}{c}\text { Características de } \\
\text { fabricação }\end{array}$ & Geotêxtil A & Geotêxtil B \\
\hline Matéria-Prima & Polipropileno (PP) & Poliéster (PET) \\
\hline Tipo de fibras & Curtas & Curtas \\
\hline Estrutura & Agulhada & Agulhada \\
\hline
\end{tabular}


TABELA 3.2 - Resultados da caracterização dos geotêxteis ensaiados.

\begin{tabular}{|c|c|c|c|c|c|c|}
\hline \multirow{3}{*}{ Material } & \multicolumn{2}{|c|}{ Ensaio de Gramatura } & \multicolumn{4}{|c|}{ Ensaio de Tração } \\
\cline { 2 - 7 } & \multicolumn{2}{|c|}{$\mathbf{( N B R ~ 1 2 5 6 8 , ~ 1 9 9 2 )}$} & \multicolumn{3}{|c|}{ (NBR 12824, 1994) } \\
\cline { 2 - 7 } & \multirow{2}{*}{$\left(\mathbf{g} / \mathbf{m}^{2}\right)$} & \multirow{2}{*}{$\mathbf{C V}(\%)$} & \multicolumn{2}{|c|}{ Sentido 1 } & \multicolumn{2}{c|}{ Sentido 2 } \\
\cline { 4 - 7 } & & & $\mathbf{( k N / m )}$ & $\mathbf{C V ( \% )}$ & $\mathbf{( k N / m )}$ & $\mathbf{C V ( \% )}$ \\
\hline A & 305 & 7,60 & 11,10 & 9,10 & 17,20 & 5,10 \\
\hline B & 336 & 11,10 & 11,50 & 20,60 & 15,40 & 12,10 \\
\hline
\end{tabular}

CV: coeficiente de variação = relação entre o desvio-padrão e a média, expresso em porcentagem.

Observação: O sentido 1 refere-se ao sentido longitudinal e o 2 ao sentido transversal

\subsection{Preparação dos corpos de prova}

Os corpos de prova foram obtidos seguindo-se às recomendações da ABNT (NBR 12593, 1992). A dimensão útil de ensaio foi de $20 \mathrm{~cm}$ x $20 \mathrm{~cm}$. Para tanto os corpos de provas foram extraídos da amostra com $20 \mathrm{~cm}$ x $50 \mathrm{~cm}$, pois as áreas não úteis foram utilizadas para a fixação às garras de tração. Essas áreas permitiram envolver a peça de fixação em uma vez e meia.

A colagem do corpo de prova na peça foi feita com uma resina epoxídica, do tipo Araldite M com endurecedor HY 956, na proporção de 5:1. A cura do corpo de prova foi de no mínimo 24 horas.

O corpo de prova foi gradeado, na área útil para que fosse possível acompanhar qualitativamente o desenvolvimento das deformações (espaçamentos de 2,5 cm x 2,5 cm). Na Figura 3.1 podemos visualizar um corpo de prova antes e depois da colagem na peça da garra. 


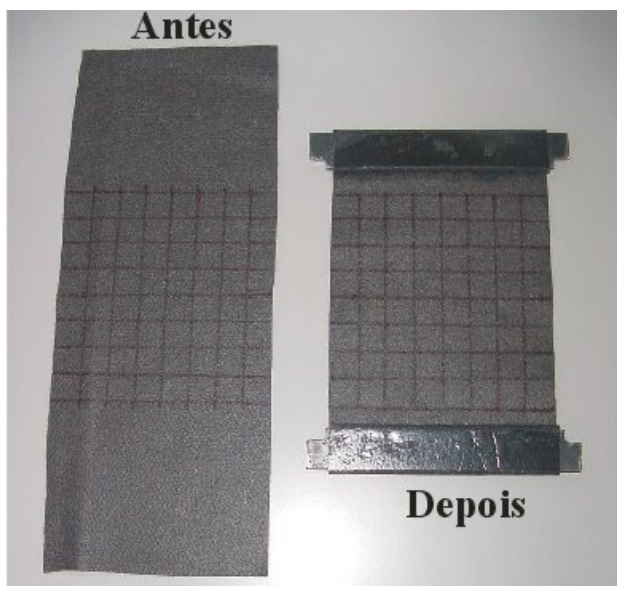

FIGURA 3.1 - Corpo de prova antes e depois da colagem na peça da garra.

\subsection{Equipamento para execução dos ensaios convencionais de fluência}

Foram utilizados suportes metálicos individuais, pois trabalhos anteriores (BARAS, 2001) mostraram a importância de se utilizar este tipo de equipamento. São cavaletes em aço, com 0,55 m de comprimento e 1,60 m de altura, observado na Figura 3.2.

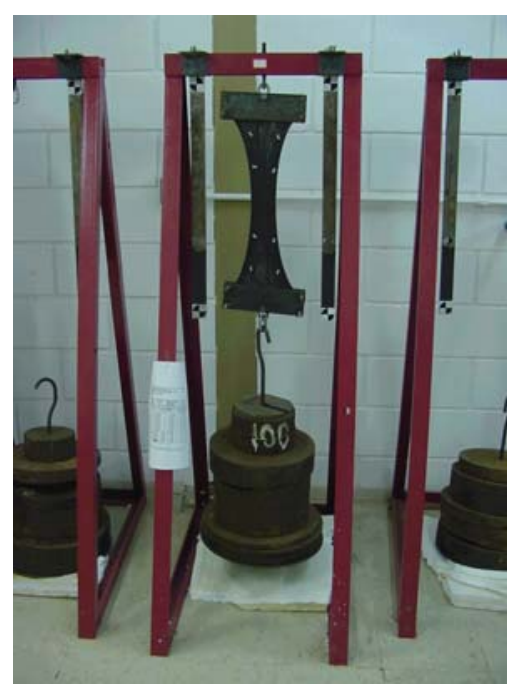

FIGURA 3.2 - Cavalete individual para ensaios de fluência. 


\subsection{Equipamento para execução dos ensaios acelerados não confinados de fluência}

\subsubsection{A Câmara de temperatura controlável}

A câmara de temperatura controlada foi projetada e construída por BARAS (2001). Trata-se de uma estrutura de madeira, com portas laterais deslizantes e janelas com dobradiças, que facilitam a operação. A câmara e o croqui de suas dimensões é mostrada na Figura 3.3, que permite visualizar o formato da estrutura.

No dimensionamento dos equipamentos necessários ao funcionamento térmico da câmara, de acordo com BARAS (2001), foram levados em consideração que os ensaios acelerados seriam feitos pelo método SIM, ou seja, altos gradientes de temperatura que deveriam ser obtidos em tempos muito pequenos. O cálculo da potência das resistências elétricas, necessárias para o funcionamento da câmara, pode ser visto em BARAS (2001).

Os instrumentos necessários ao controle de temperatura no interior da caixa são seis resistências elétricas (15 kW), cinco ventiladores internos Nework modelo NW 309RT-080 de 14 a 16 watts, responsáveis pela circulação do ar quente, seis ventiladores externos do mesmo modelo, responsáveis em jogar ar externo para dentro da caixa e sensores de temperatura do tipo termopar "k". Externamente, há um controlador de temperatura e uma chave contatora. Em termos de funcionamento, a câmara permite que os gradientes de temperatura se estabilizem entre 10 e 50 segundos, tempo que se verificou ser satisfatório para o propósito do ensaio. Na Figura 3.3 pode-se perceber que a câmara se insere em um pórtico, no seu interior se colocam apenas o $\mathrm{CP}$ e as réguas de referência, além dos dispositivos funcionais como as resistências e os ventiladores. 


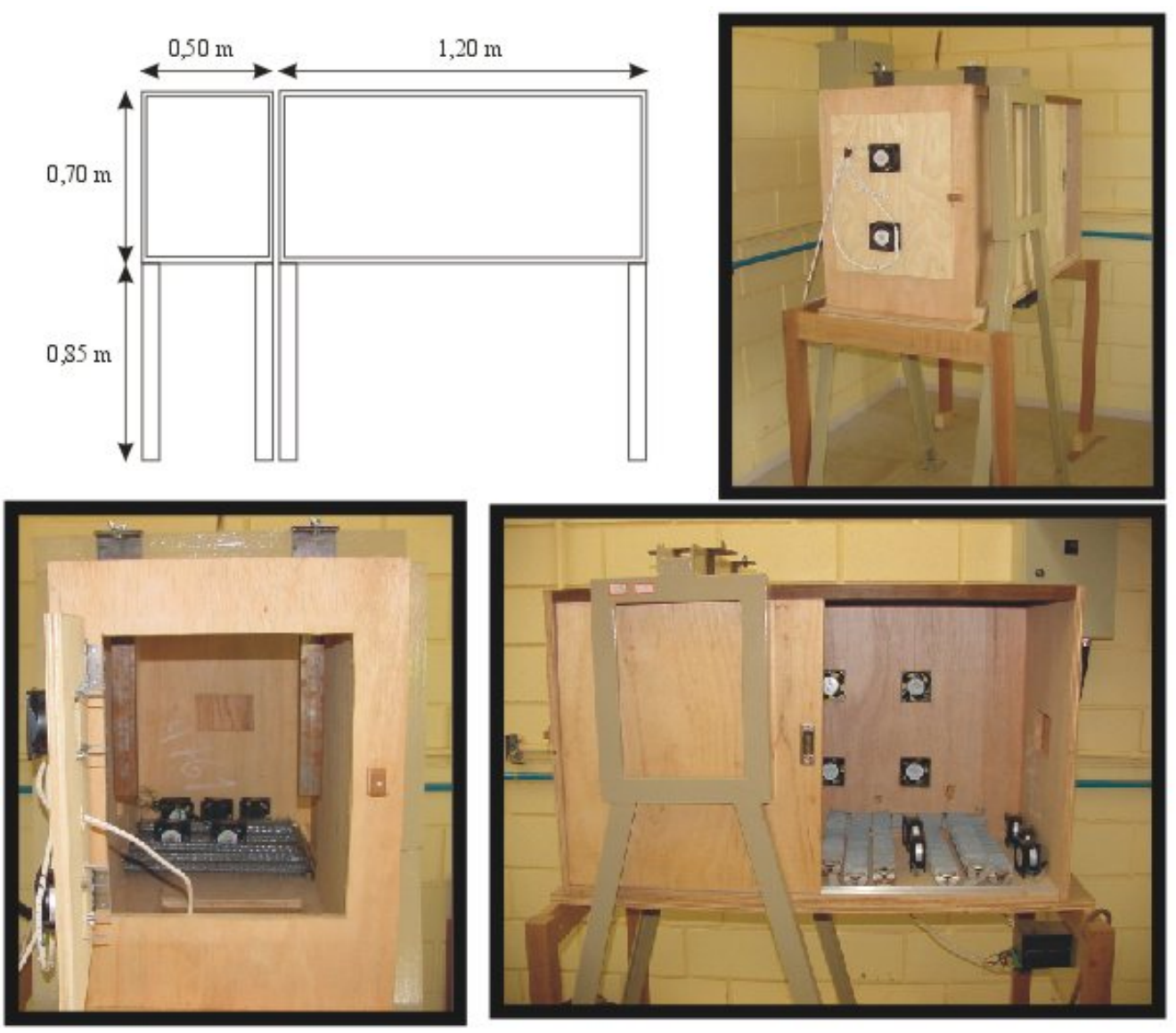

FIGURA 3.3 - Câmara de temperatura controlável.

\subsubsection{Cavalete metálico para execução dos ensaios acelerados}

Para a execução dos ensaios acelerados, foi confeccionado um outro pórtico, com capacidade para apenas um ensaio, com a altura de 1,60 $\mathrm{m}$ e comprimento de 0,60 $\mathrm{m}$. As demais características dos pórticos dos ensaios convencionais foram mantidas. Esse cavalete pode ser visto na Figura 3.3.

\subsection{Sistema de ancoragem e de aplicação de cargas}

O sistema de ancoragem é semelhante ao utilizado por COSTA (1999) em que as garras são compostas por barras de aço, sendo cada garra constituída por um conjunto de quatro peças divididas em dois tipos, duas menores (37 mm x $240 \mathrm{~mm}$ x 6,35 mm) e duas maiores 
(77 mm x 240 mm x 7,94 mm). A fixação ocorre enrolando-se o geotêxtil em uma das barras menores que é então encostada na outra peça de mesmo tipo, sendo ambas pressionadas pelas barras maiores. Todo o conjunto é, por fim, conectado através de parafusos. A presença de um recorte nas barras menores permite que mesmas se apóiem nos parafusos que atravessam as peças maiores. Esse sistema pode ser visualizado na Figura 3.4.

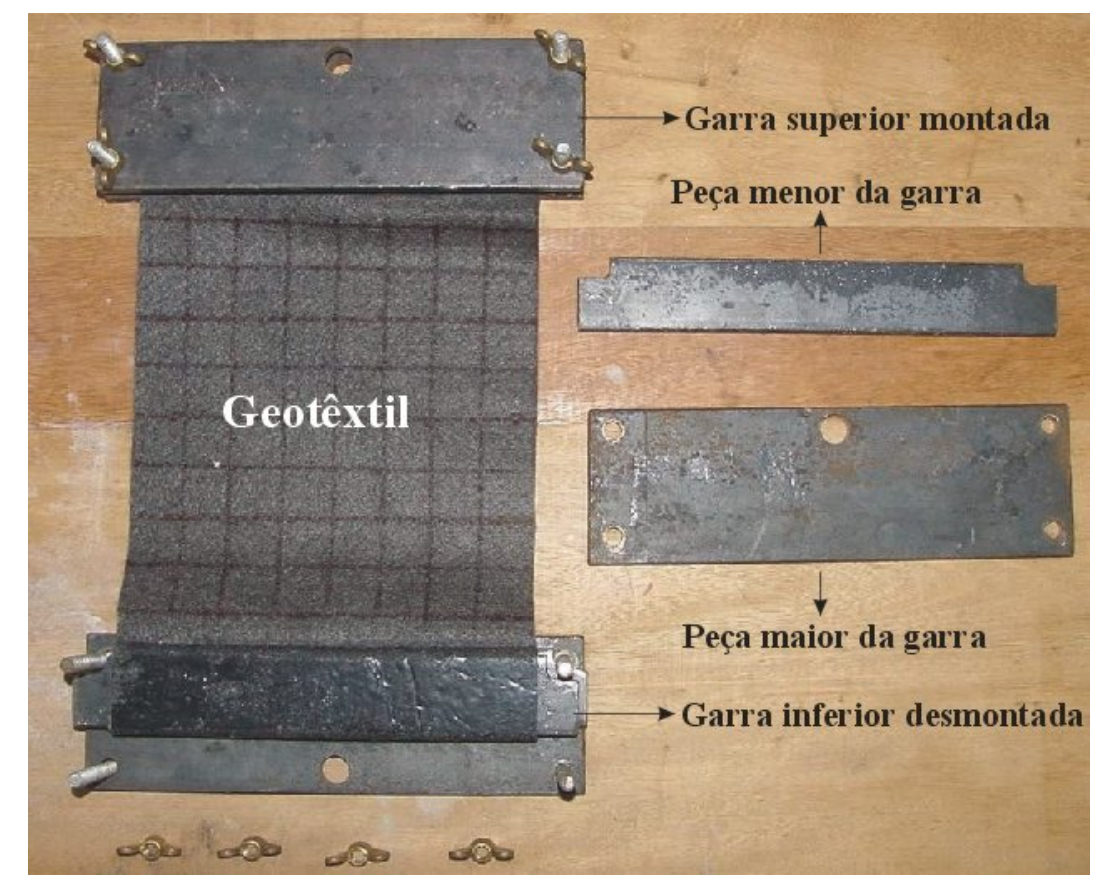

FIGURA 3.4 - Conjunto garra/geotêxtil utilizada nos ensaios.

Para aplicação dos carregamentos foram utilizados pesos de aço apoiados em um pendural também de aço. A Figura 3.5 mostra um conjunto de aplicação de carga já montado em um ensaio. 


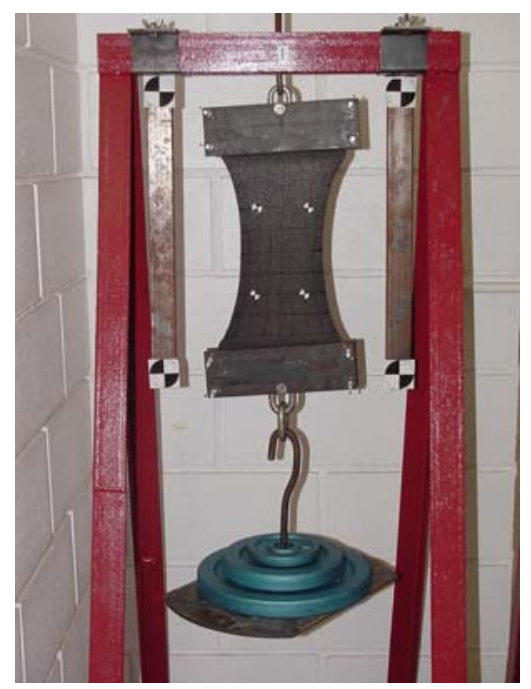

FIGURA 3.5 - Sistema de aplicação de carga em ensaio montado

Para auxiliar a montagem dos ensaios, foram utilizados dois macacos hidráulicos, um do tipo jacaré e outro do tipo girafa, uma vez que as cargas eram altas. Esses macacos podem ser visualizados na Figura 3.6 e 3.7, respectivamente.

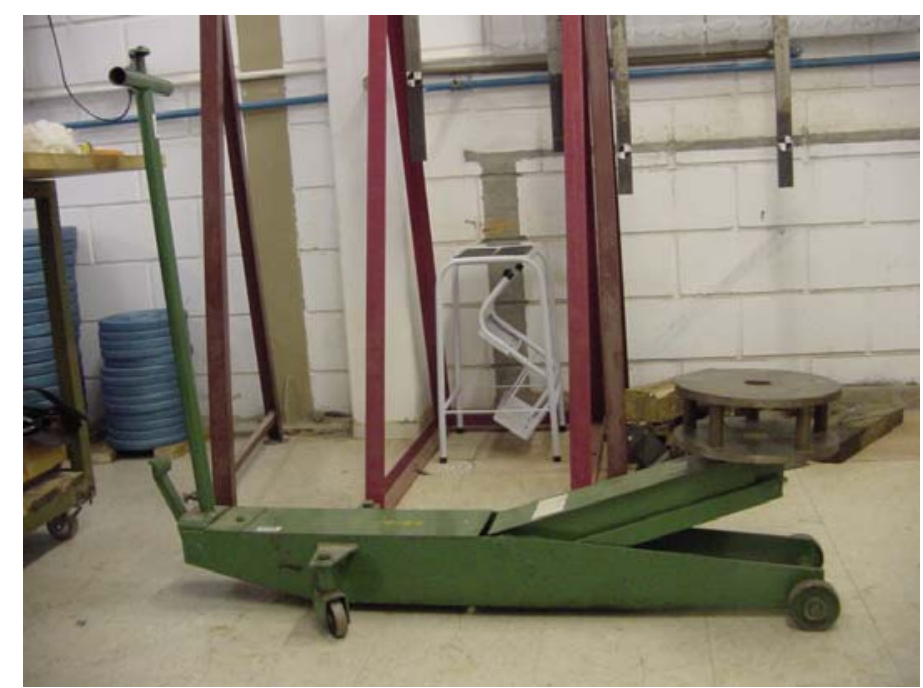

FIGURA 3.6 - Macaco hidráulico do tipo jacaré. 


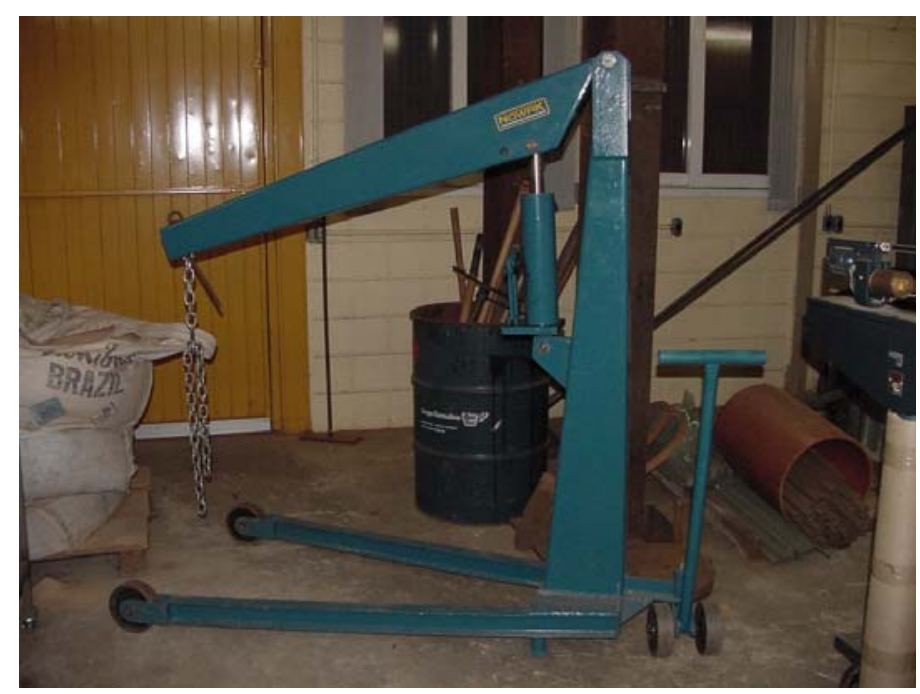

FIGURA 3.7 - Macaco hidráulico do tipo girafa.

\subsection{Equipamento utilizado para executar os ensaios de ruptura por fluência convencional}

Para executar os ensaios de ruptura por fluência, onde as cargas aplicadas são superiores a 85\% da carga de ruptura obtida pelos ensaios em faixa larga (ABNT 12582), optou-se pela utilização da máquina universal de ensaios com capacidade máxima de 30kN, da marca EMIC, modelo DL - 3000, com garra projetada para essa finalidade e célula de carga de sensibilidade de 30kN modelo Z3T, também da marca EMIC. Esta escolha se deve ao fato destes ensaios exigirem cargas muito elevadas, mais de $250 \mathrm{~kg}$, situação difícil de ser executada utilizando-se peso morto. A Máquina Universal de ensaios, a garra e a célula de carga podem ser visualizadas na Figura 3.8. 


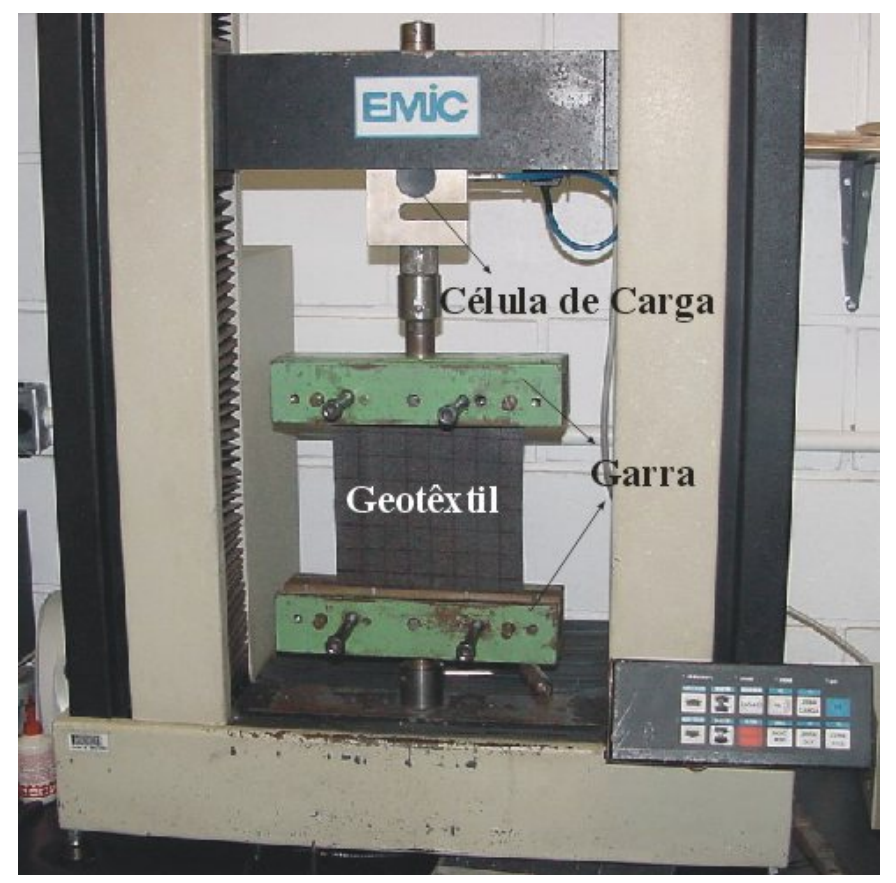

FIGURA 3.8 - Presa, célula de carga e garra utilizados nos ensaios de ruptura por fluência.

\subsection{Sistema de leitura dos alongamentos}

O método utilizado para a leitura dos alongamentos utilizado nos ensaios de fluência convencional e acelerados foi o fotográfico, descrito por BUENO (1987), e adaptado para os ensaios de fluência por BARAS (2001). O princípio básico baseia-se no conhecimento da posição real de pontos que possam determinar um plano, chamado de referências globais. Com essas referências pode-se conhecer a posição real de qualquer ponto presente numa imagem a ser trabalhada, através de um fator de escala em um modelo matemático simples que pode ser visto em BUENO (1987). O modelo é muito simples, e utiliza duas equações básicas:

$X=A+B x+C y+D y+\ldots$

$Y=A^{\prime}+B^{\prime} x+C^{\prime} y+D^{\prime} x y+\ldots$ 
Sendo:

$\mathrm{X}$ e Y: as coordenadas globais ou reais do ponto em questão;

$\mathrm{x}$ e y: as coordenadas locais do ponto em questão;

A, A’, B, B', C, C’, D, D’, ...: as constantes de transformação de coordenadas do sistema.

Desta forma, cada foto tem suas próprias constantes obtidas aplicando-se às equações 3.3 e 3.4 as coordenadas globais e locais dos pontos de referência. Após a obtenção destas constantes, têm-se as equações capazes de obter as posições reais de pontos na foto relativas ao sistema de coordenadas criados. De acordo com BARAS (2001) esse método apresentou boa acurácia, e tem a grande vantagem de evitar a preocupação com o deslizamento relativo entre a garra e o geotêxtil em ensaios de fluência ou com os cursos de extensômetros ou LVDT’s.

As fotografias ao longo do tempo foram feitas com uma máquina fotográfica digital da marca SONY, modelo MVC - PD95, que permitiram acompanhar os deslocamentos dos CPs.

Para uma otimização do processo de obtenção dos alongamentos foi desenvolvido um programa chamado de TRATAMENTO. O programa, em sua versão atual, faz os cálculos das deformações, sendo necessário que o usuário entre com os dados das coordenadas globais e que marque as posições das miras referentes aos pontos das coordenadas globais e as miras dos pontos aos quais se desejam serem calculados os deslocamentos. A tela principal deste programa pode ser visualizada na Figura 3.9. 


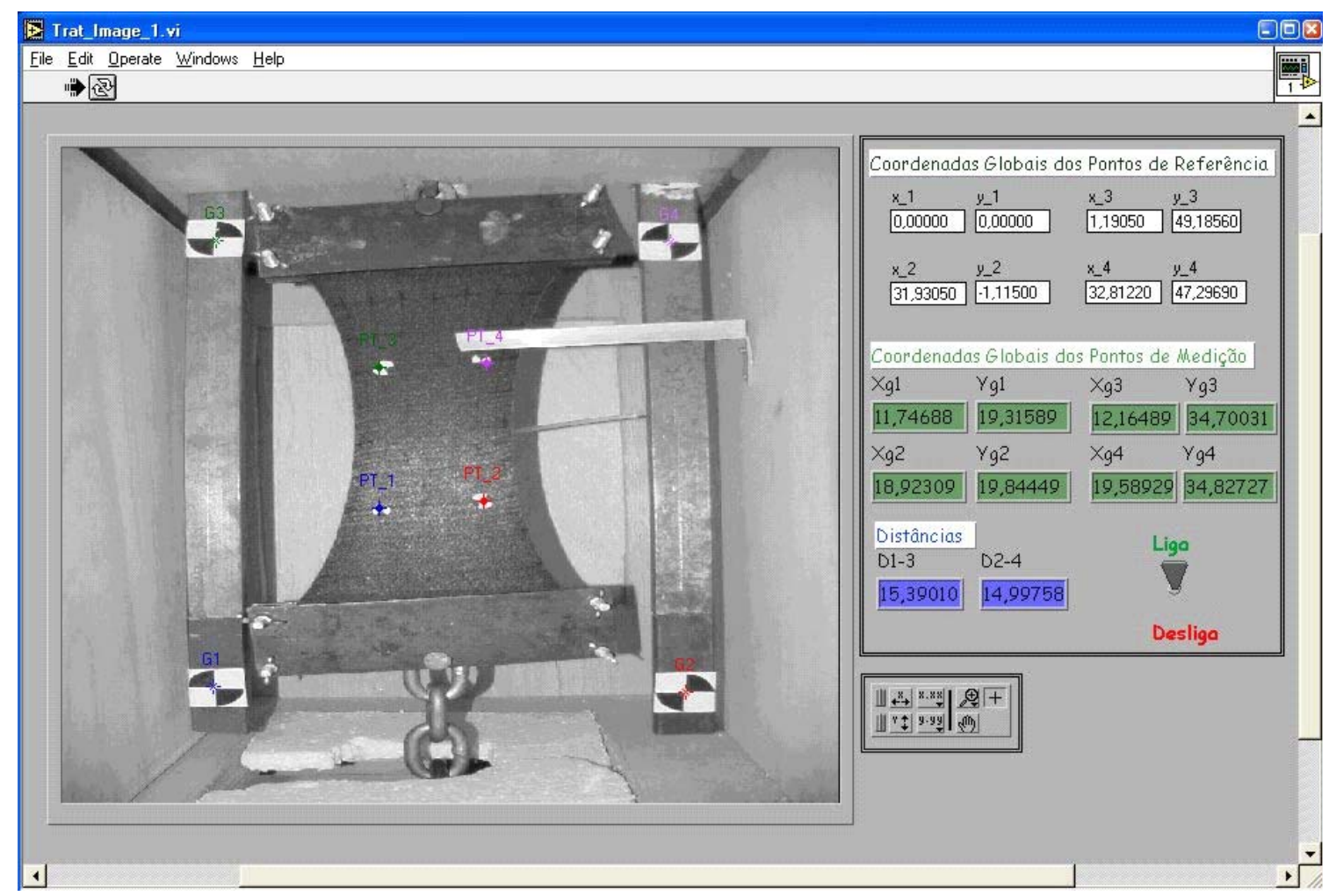

FIGURA 3.9 - Tela principal do programa TRATAMENTO.

Para obtenção das deformações ao longo do tempo dos ensaios de ruptura por fluência, realizados no equipamento universal de ensaios, foi utilizado o programa TESC desenvolvido pela EMIC, versão 1.08 para Windows 98/98/NT4.

\subsection{Procedimento dos ensaios convencionais de fluência}

Os ensaios convencionais de fluência foram realizados de acordo com a norma ISO 13431, uma vez que a norma brasileira para este ensaio está em fase de aprovação. Estes ensaios tem duração de 1008 horas.

As cargas aplicadas foram equivalentes a uma porcentagem da resistência a tração (UTS) dos materiais ensaiados. Os níveis de carregamento utilizados foram de 10, 20, 40 e 60\% UTS obtida pela ABNT - NBR 12824. Estes ensaios foram realizados no laboratório de geossintéticos do Departamento de Geotecnia da Escola de Engenharia de São Carlos (EESC-USP) que atende os requisitos de temperatura e umidade do ar, ou seja, temperatura entre $21 \pm 2^{\circ} \mathrm{C}$ e umidade de $65 \pm 2 \%$. 
Após a preparação dos CP, prende-se o geotêxtil, já colados às peças, no conjunto de garras, já em posição de ensaio, no pórtico. Devido à dificuldade de se aplicar pré-carga específica, considerou-se esta, em todos os ensaios, igual ao peso do conjunto da garra inferior. A leitura de pré-carga foi feita no menor tempo possível. Após esta, o passo seguinte é aplicação do carregamento, que foi feito de forma suave, sem causar repique e menos de 30 segundos. Após o total carregamento é que o cronômetro foi acionado.

A partir do momento em que se iniciava a contagem de tempo, as deformações foram obtidas para os seguintes tempos pré-determinados: 1, 2, 4, 8, 15, 30 minutos, 1, 2, 4, 8, 24 horas, 3, 7, 14, 21 e 42 dias.

\subsection{Procedimento dos ensaios acelerados de fluência}

Os ensaios acelerados de fluência foram baseados nessa mesma norma, e os níveis de carregamento foram os mesmos dos ensaios convencionais, ou seja, 10, 20, 40 e 60\% da resistência à tração, para se verificar a aplicabilidade do método SIM testado.

A parte inicial do ensaio é similar ao ensaio convencional, que compreende a preparação do $\mathrm{CP}$, sua instalação no pórtico, a leitura do pré-carregamento e o carregamento propriamente dito. Deve-se salientar que este ensaio foi realizado na câmara de temperatura controlável, e que foi necessário a instalação de um sensor de temperatura, do tipo termopar K, com o auxilio de uma tachinha presa com uma tarraxa de borracha, para que esta não se solta-se do corpo de prova.

O procedimento adotado foi similar ao de BARAS (2001), onde o ensaio foi dividido em 4 estágios de temperatura diferentes, começando à temperatura ambiente, passando-se em seguida para $40^{\circ} \mathrm{C}$, depois para $50^{\circ} \mathrm{C}$ e por fim a $60^{\circ} \mathrm{C}$. A temperatura ambiente variou de $18^{\circ}$ a $26^{\circ} \mathrm{C}$, e a rampa de variação de temperatura, ou períodos de elevação de temperatura, atingiram o tempo máximo de um minuto. O procedimento é descrito a seguir: 
- $1^{\circ}$ estágio: patamar de 2 horas à temperatura ambiente;

- $2^{\circ}$ estágio: elevação da temperatura até $40^{\circ} \mathrm{C}$ e patamar de 2 horas de ensaio nesta temperatura;

- $\quad 3^{\circ}$ estágio: elevação da temperatura em $10^{\circ} \mathrm{C}$ e patamar de 2 horas de ensaio em $50^{\circ} \mathrm{C}$;

- $4^{\circ}$ estágio: elevação da temperatura em $10^{\circ} \mathrm{C}$ e patamar de 2 horas de ensaio em $60^{\circ} \mathrm{C}$.

A programação de rampas e patamares foi mantida constante para todos os ensaios de fluência acelerados para uma futura comparação e análise dos resultados.

As deformações foram obtidas para os seguintes tempos pré-determinados: 1, 2, 4, 8, 15, 30 minutos, 1 e 2 horas para cada patamar de temperatura (temperatura ambiente, $40^{\circ} \mathrm{C}$, $50^{\circ} \mathrm{C}$ e $\left.60^{\circ} \mathrm{C}\right)$

Para se executar a translação horizontal e obter a curva mestra de fluência (exata justaposição das curvas com inclinações semelhantes) e os tempos de ruptura simulados, seguiram-se as recomendações de THORNTON et al., (1997) FARRAG e SHIRAZI (1997). Nelas estes autores indicam que o ajuste entre as curvas deve ser tal que o coeficiente angular para o trecho final de uma curva seja o mais próximo possível do valor deste coeficiente para o trecho inicial da curva de temperatura imediatamente superior. No presente caso, o cálculo dos coeficientes angulares foi feito através do método dos mínimos quadrados, obtendo-se o maior valor do parâmetro $\mathrm{R}^{2}$ para junção dos pares de segmento. Esse parâmetro foi obtido utilizando-se os três últimos pontos da curva de menor temperatura com os três primeiros pontos da curva de temperatura imediatamente superior. O fator de translação é definido como o quanto se desloca horizontalmente a curva na escala logaritmo do tempo, promovendo a sua linearização.

\subsection{Procedimento dos ensaios convencionais de ruptura por fluência}

Os ensaios convencionais de ruptura por fluência também foram realizados de acordo com a norma ISO 13431. Os níveis de carregamento utilizados foram de 85 e 90\% UTS, obtida pela ABNT - NBR 12824, para que junto dos ensaios acelerados fosse possível a obtenção de uma curva de ruptura mais completa. Novamente, estes ensaios foram 
realizados em laboratório que atende os requisitos de temperatura e umidade do ar, ou seja, temperatura entre $21 \pm 2^{\circ} \mathrm{C}$ e umidade de $65 \pm 2 \%$.

Para estes ensaios é necessário que os CPs sejam cortados na dimensão desejada, 20 cm $\mathrm{x} \pm 35 \mathrm{~cm}$, para que a área útil de ensaio seja de $20 \mathrm{~cm}$ x $20 \mathrm{~cm}$, montagem deste na máquina universal de ensaios, em uma garra especialmente projetada para esta finalidade, seguido de uma pré-carga e o carregamento, que é feito pelo equipamento através de uma rotina de ensaio já definida no programa TESC. As deformações são obtidas também pelo programa em intervalos de tempo pré-determinados pelo mesmo.

\subsection{Procedimento dos ensaios acelerados de ruptura por fluência}

Os ensaios acelerados de ruptura por fluência, mais uma vez, foram baseados segundo a norma ISO 13431. Os ensaios de ruptura acelerados seguiram o mesmo procedimento dos ensaios de fluência acelerados, mas agora com estágios de 12 horas de duração cada, com mais um patamar de $70^{\circ} \mathrm{C}$, ou até a ruptura da amostra. O procedimento esta descrito abaixo:

- $1^{\circ}$ estágio: patamar de 12 horas à temperatura ambiente;

- $2^{\circ}$ estágio: elevação da temperatura até $40^{\circ} \mathrm{C}$ e patamar de 12 horas de ensaio nesta temperatura;

- $3^{\circ}$ estágio: elevação da temperatura em $10^{\circ} \mathrm{C}$ e patamar de 12 horas de ensaio em $50^{\circ} \mathrm{C}$;

- $4^{\circ}$ estágio: elevação da temperatura em $10^{\circ} \mathrm{C}$ e patamar de 12 horas de ensaio em $60^{\circ} \mathrm{C}$;

- $5^{\circ}$ estágio: elevação da temperatura em $10^{\circ} \mathrm{C}$ e patamar de 12 horas de ensaio.

A temperatura ambiente variou entre $18^{\circ} \mathrm{C}$ e $26^{\circ} \mathrm{C}$. Os períodos de elevação de temperatura atingiram o tempo máximo de um minuto. $\mathrm{O}$ ensaio foi realizado totalizando 60 horas ou até a ruptura dos corpos de prova.

As deformações foram obtidas para os seguintes tempos pré-determinados: 1, 2, 4, 8, 15, 30 minutos, 1, 2, 6 e 12 horas para cada patamar de temperatura (temperatura ambiente, $40^{\circ} \mathrm{C}, 50^{\circ} \mathrm{C}$ e $\left.60^{\circ} \mathrm{C}\right)$. 
Para se executar a translação horizontal e obter a curva mestra de fluência e os tempos de ruptura simulados foi utilizado a mesma metodologia descrita no para os ensaios acelerados de fluência. 


\section{CAPÍTULO 4}

\section{APRESENTAÇÃO E ANÁLISE DOS RESULTADOS}

Este capítulo está dividido em duas partes principais. Na primeira, faz-se a apresentação e discussão dos resultados dos ensaios de fluência de ambos materiais ensaiados, incluindo as análises. Na segunda, são apresentados e analisados os resultados dos ensaios de ruptura por fluência.

\subsection{Ensaios de fluência}

\subsubsection{Fluência do geotêxtil A}

Foram executados 16 ensaios para o produto A, sendo quatro convencionais e doze acelerados. As respostas das deformações por fluência em função do tempo para os ensaios acelerados são apresentadas na Figura 4.1. Estes resultados permitem o cálculo dos módulos de fluência, definido como a relação entre o carregamento e deformação específica, cujos resultados são mostrados na Figura 4.2. 


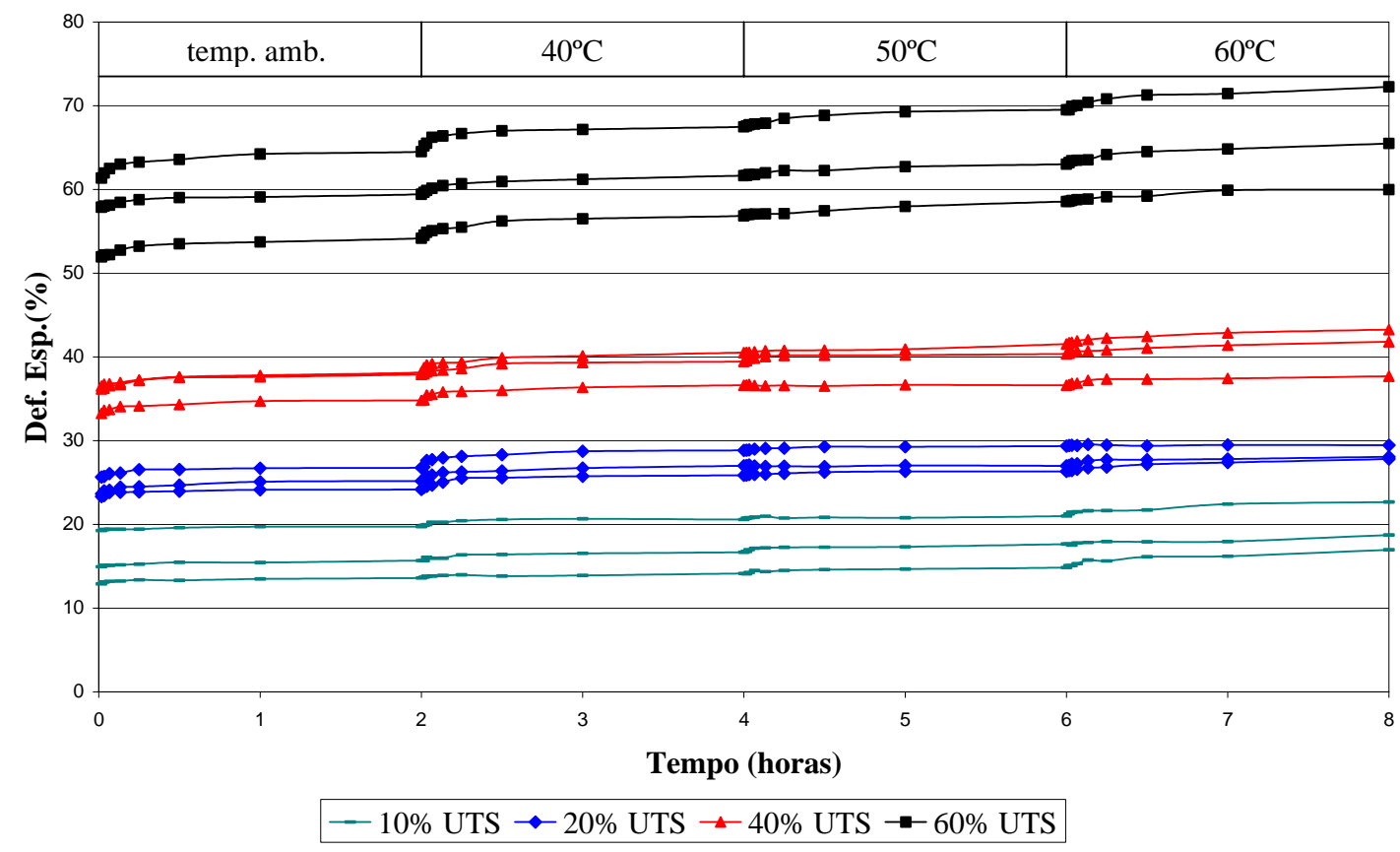

FIGURA 4.1 - Curvas das deformações por fluência em função do tempo para 10, 20, 40 e 60\% UTS obtidas com ensaios acelerados no geotêxtil A.

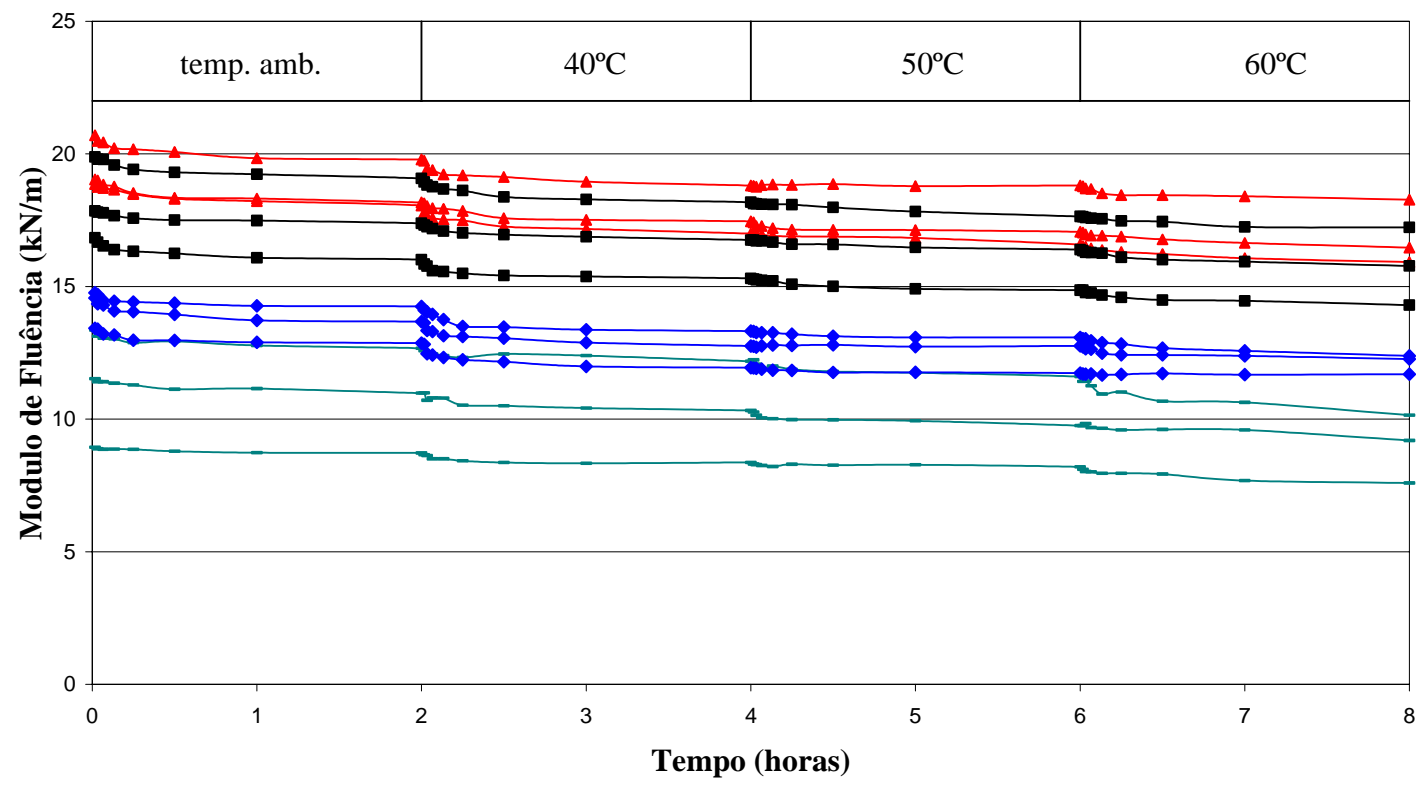

$-10 \%$ UTS $\rightarrow-20 \%$ UTS $\rightarrow-40 \%$ UTS $\rightarrow-60 \%$ UTS

FIGURA 4.2 - Curvas dos módulos de fluência em função do tempo para 10, 20, 40 e 60\% UTS obtidas com ensaios acelerados para o geotêxtil A. 
Com os dados da Figura 4.1, aplicou-se o princípio de translação tempo-temperatura (TTS). As curvas mestras resultantes do método SIM e as curvas obtidas com os ensaios convencionais de fluência podem ser vistas na Figura 4.3. Os corpos de prova CP1A, CP5A, CP9A e CP13A foram ensaiados durante 1008 horas (ensaio convencional). Por fim, na Figura 4.4, mostram-se curvas mestras de módulo de fluência versus log do tempo.

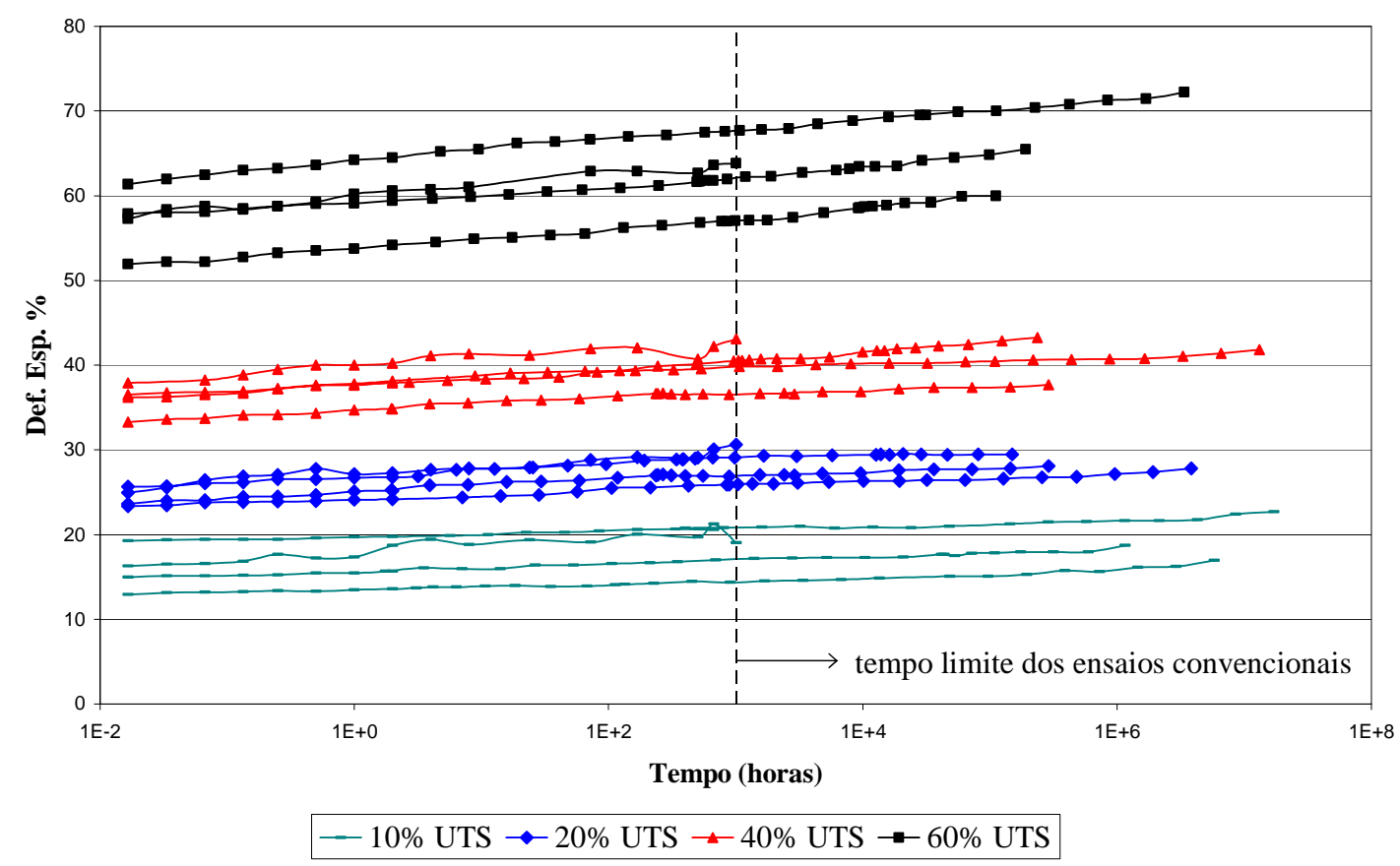

FIGURA 4.3 - Curvas mestras obtidas pelo SIM e curvas convencionais para 10, 20, 40 e 60\% UTS para o geotêxtil A. 


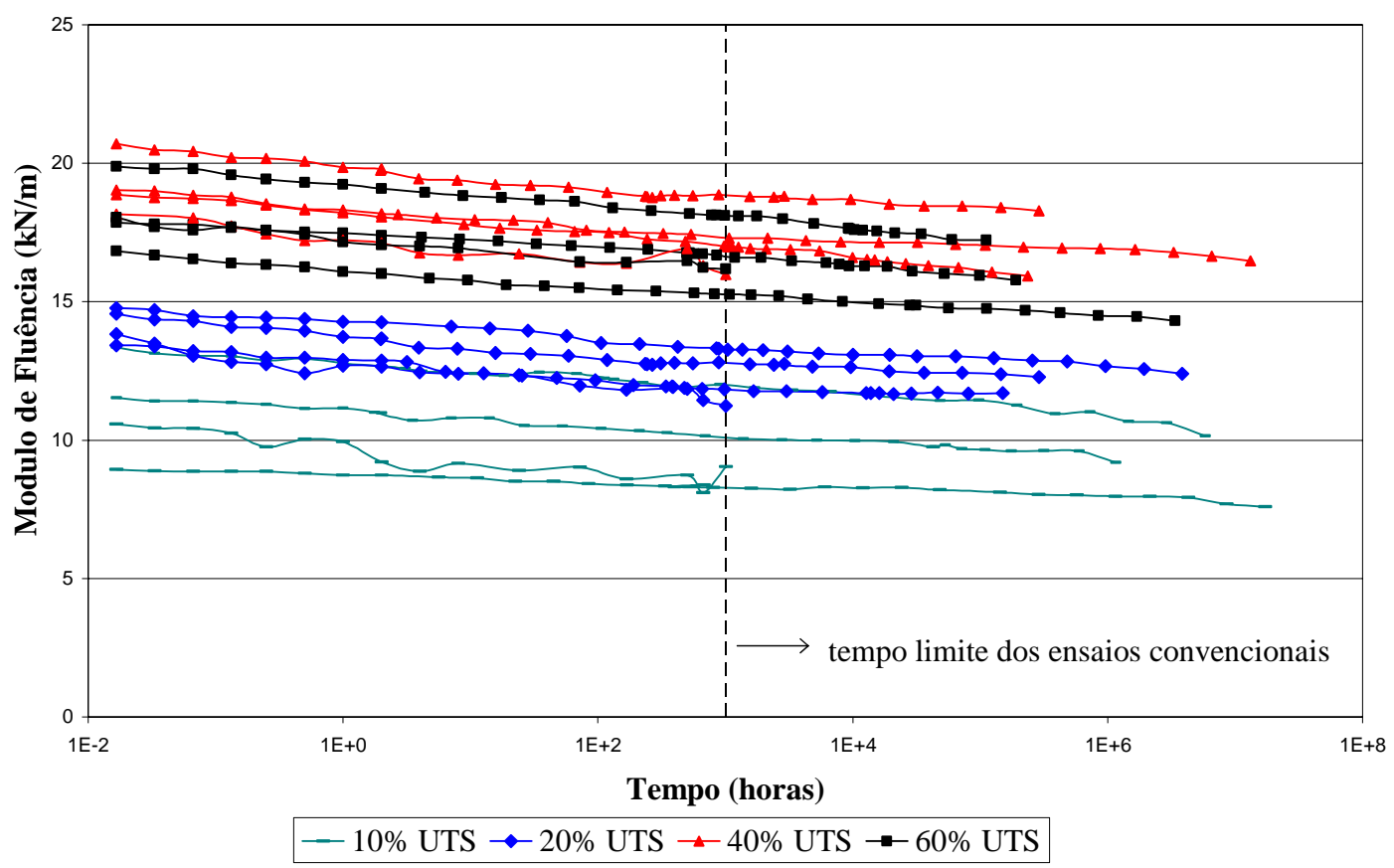

FIGURA 4.4 - Curvas mestras do módulo de fluência obtidas pelo SIM e curvas convencionais para 10, 20, 40 e 60\% UTS para o geotêxtil A.

Os resultados mostram que as curvas mestras para o polipropileno tiveram um alcance muito disperso, variando de 13 a 1959 anos. Essa diferença apesar de ser grande pode ser considerada satisfatória, pois uma pequena variação obtida no cálculo do tempo de inicio virtual, obtido pelo método dos mínimos quadrados, implica em grande variação do alcance. Isto se deve ao fato do tempo ser lançado em escala logarítmica, em que, para tempos elevados, um pequeno deslocamento do ponto, no eixo horizontal, representa uma grande variação de tempo. Outro fator que pode influenciar nesta diferença é a variabilidade de propriedades mecânicas do material que ocorre de amostra para amostra. Na Tabela 4.1, são mostrados os tempos de alcance para cada corpo de prova. A ordem de grandeza dos tempos alcançados pelo método SIM para os produtos testados é equivalente aos tempos obtidos por outros autores que utilizaram este método de ensaio como, por exemplo, Thornton et al. (1998). 
TABELA 4.1 - Resultados dos tempos de alcance do geotêxtil A.

\begin{tabular}{|c|c|c|c|}
\hline $\begin{array}{c}\text { Carregamento } \\
\text { (UTS) }\end{array}$ & $\mathbf{C P}$ & Tipo de ensaio & $\begin{array}{c}\text { Tempo de alcance } \\
\text { (anos) }\end{array}$ \\
\hline \multirow{4}{*}{$10 \%$} & $1 \mathrm{~A}$ & Convencional & - \\
\hline & $2 \mathrm{~A}$ & SIM & 664 \\
\hline & $3 \mathrm{~A}$ & SIM & 1959 \\
\hline & $4 \mathrm{~A}$ & SIM & 132 \\
\hline \multirow{4}{*}{$20 \%$} & $5 \mathrm{~A}$ & Convencional & - \\
\hline & $6 \mathrm{~A}$ & SIM & 17 \\
\hline & $7 \mathrm{~A}$ & SIM & 33 \\
\hline & $8 \mathrm{~A}$ & SIM & 438 \\
\hline \multirow{4}{*}{$40 \%$} & $9 \mathrm{~A}$ & Convencional & - \\
\hline & $10 \mathrm{~A}$ & SIM & 1500 \\
\hline & $11 \mathrm{~A}$ & SIM & 33 \\
\hline & $12 \mathrm{~A}$ & SIM & 27 \\
\hline \multirow{4}{*}{$60 \%$} & $13 \mathrm{~A}$ & Convencional & - \\
\hline & $14 \mathrm{~A}$ & SIM & 386 \\
\hline & $15 \mathrm{~A}$ & SIM & 13 \\
\hline & $16 \mathrm{~A}$ & SIM & 22 \\
\hline
\end{tabular}

Visualmente ocorreu uma ótima concordância entre os métodos SIM e convencional. Para analisar os dados pode-se, por exemplo, utilizar os coeficientes angulares das retas obtidos através de regressão linear para todos os ensaios. Esses resultados podem ser vistos na Tabela 4.2. O modelo utilizado foi:

$$
y=a \cdot \ln (x)+b
$$


TABELA 4.2 - Coeficientes obtidos por regressão linear para as curvas do geotêxtil A.

\begin{tabular}{|c|c|c|c|c|c|}
\hline Carregamento & $\mathbf{C P}$ & $\begin{array}{c}\text { Deformação } \\
\text { Inicial (\%) }\end{array}$ & $\mathbf{a}$ & $\mathbf{b}$ & $\mathbf{R}^{\mathbf{2}}$ \\
\hline \multirow{4}{*}{$\mathbf{1 0 \%}$} & $1 \mathrm{~A}$ & 16,27 & 0,37 & 17,85 & 0,833 \\
\cline { 2 - 6 } & $2 \mathrm{~A}$ & 12,89 & 0,16 & 13,45 & 0,943 \\
\cline { 2 - 6 } & $3 \mathrm{~A}$ & 19,25 & 0,14 & 19,72 & 0,955 \\
\cline { 2 - 6 } & $4 \mathrm{~A}$ & 14,94 & 0,19 & 15,61 & 0,984 \\
\hline \multirow{4}{*}{$\mathbf{2 0 \%}$} & $5 \mathrm{~A}$ & 24,91 & 0,40 & 27,19 & 0,890 \\
\cline { 2 - 7 } & $6 \mathrm{~A}$ & 25,64 & 0,27 & 26,90 & 0,949 \\
\cline { 2 - 7 } & $7 \mathrm{~A}$ & 23,63 & 0,26 & 25,12 & 0,949 \\
\cline { 2 - 7 } & $8 \mathrm{~A}$ & 23,32 & 0,22 & 24,20 & 0,981 \\
\hline \multirow{4}{*}{$\mathbf{4 0 \%}$} & $9 \mathrm{~A}$ & 37,92 & 0,39 & 39,89 & 0,853 \\
\cline { 2 - 7 } & $10 \mathrm{~A}$ & 36,17 & 0,26 & 37,64 & 0,976 \\
\cline { 2 - 7 } & $11 \mathrm{~A}$ & 33,26 & 0,26 & 34,74 & 0,949 \\
\cline { 2 - 7 } & $12 \mathrm{~A}$ & 36,50 & 0,40 & 37,83 & 0,991 \\
\hline \multirow{5}{*}{$\mathbf{6 0 \%}$} & $13 \mathrm{~A}$ & 57,24 & 0,56 & 59,91 & 0,973 \\
\cline { 2 - 7 } & $14 \mathrm{~A}$ & 61,35 & 0,53 & 64,08 & 0,994 \\
\cline { 2 - 7 } & $15 \mathrm{~A}$ & 51,94 & 0,51 & 53,72 & 0,991 \\
\cline { 2 - 7 } & $16 \mathrm{~A}$ & 57,87 & 0,45 & 59,15 & 0,978 \\
\hline
\end{tabular}

As curvas de fluência obtidas com ensaios convencionais e pelo SIM mostram boa concordância (Figura 4.3). A principal diferença entre curvas de mesmo UTS diz respeito basicamente ao valor da deformação inicial. Os ensaios convencionais de 10 e 20\% apresentam discrepâncias nos coeficientes angulares em relação ao método SIM. O coeficiente angular tende a crescer com o aumento do nível de carregamento, exceto para os CP9A. 


\subsubsection{Fluência do geotêxtil $B$}

Analogamente ao produto A, foram executados 16 ensaios com o geotêxtil B, sendo quatro convencionais e doze acelerados. Os níveis de carregamento e número de ensaios executados foram os mesmos que para o material A. As deformações por fluência em função do tempo são apresentadas na Figura 4.5. Os módulos de fluência versus tempo, na Figura 4.6. As curvas mestras de fluência e do módulo de fluência estão lançadas nas Figuras 4.7 e 4.8, respectivamente.

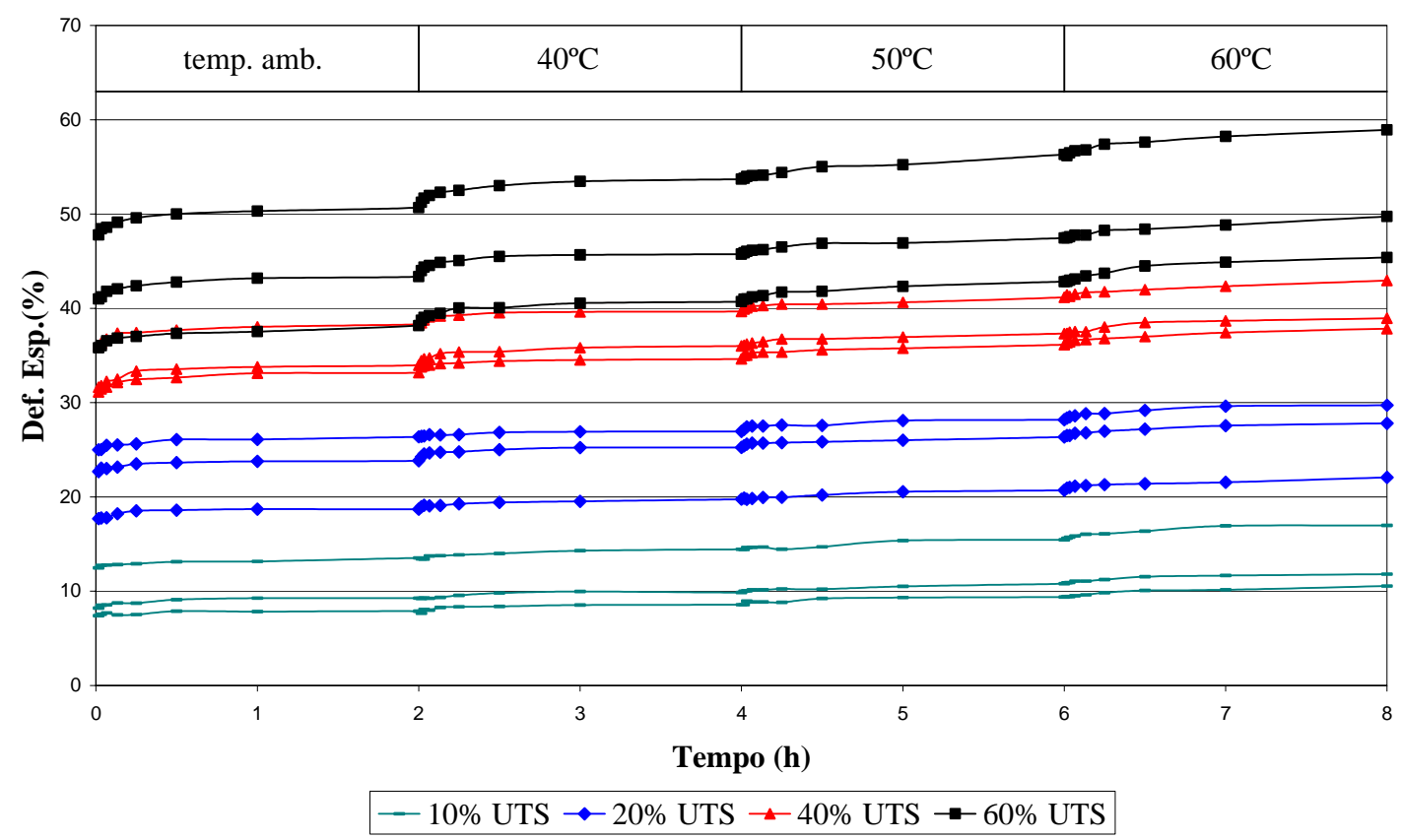

FIGURA 4.5 - Curvas das deformações por fluência em função do tempo para 10, 20, 40 e 60\% UTS obtidas com ensaios acelerados no geotêxtil B. 


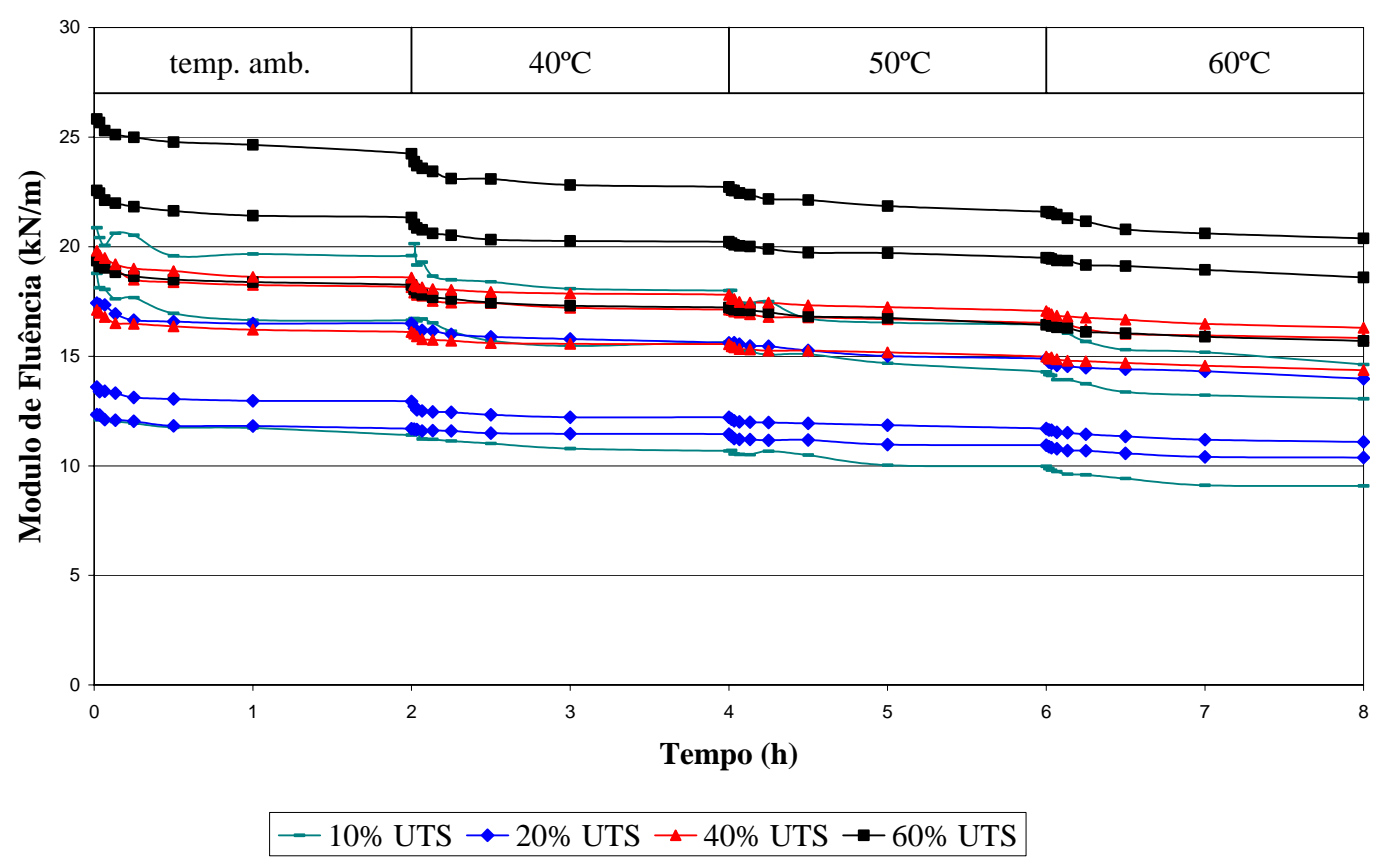

FIGURA 4.6 - Curvas dos módulos de fluência em função do tempo para 10, 20, 40 e 60\% UTS obtidas com ensaios acelerados para o geotêxtil B.

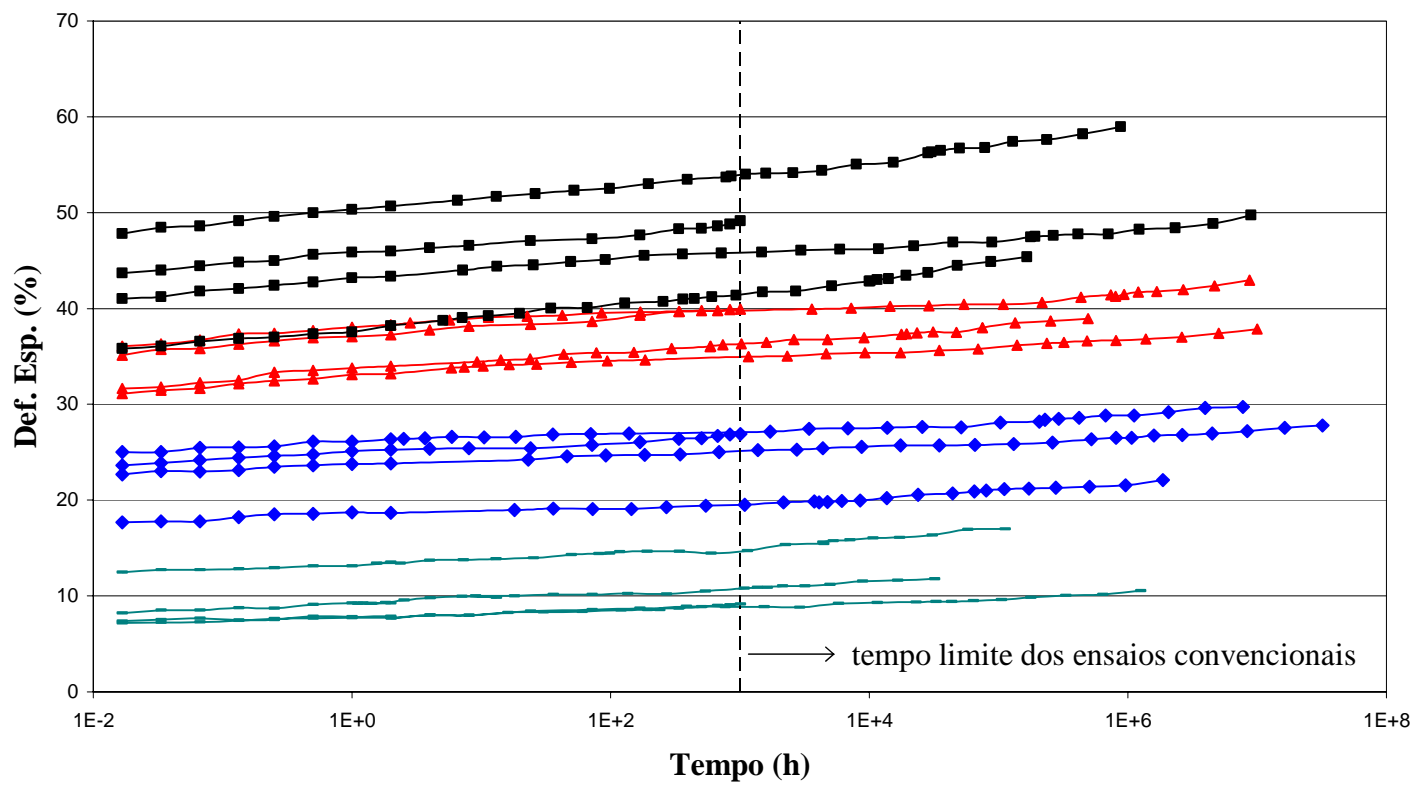

$-10 \%$ UTS $\bullet-20 \%$ UTS $\neg-40 \%$ UTS $--60 \%$ UTS

FIGURA 4.7 - Curvas mestras obtidas pelo SIM e curvas convencionais para 10, 20, 40 e $60 \%$ UTS para o geotêxtil B. 


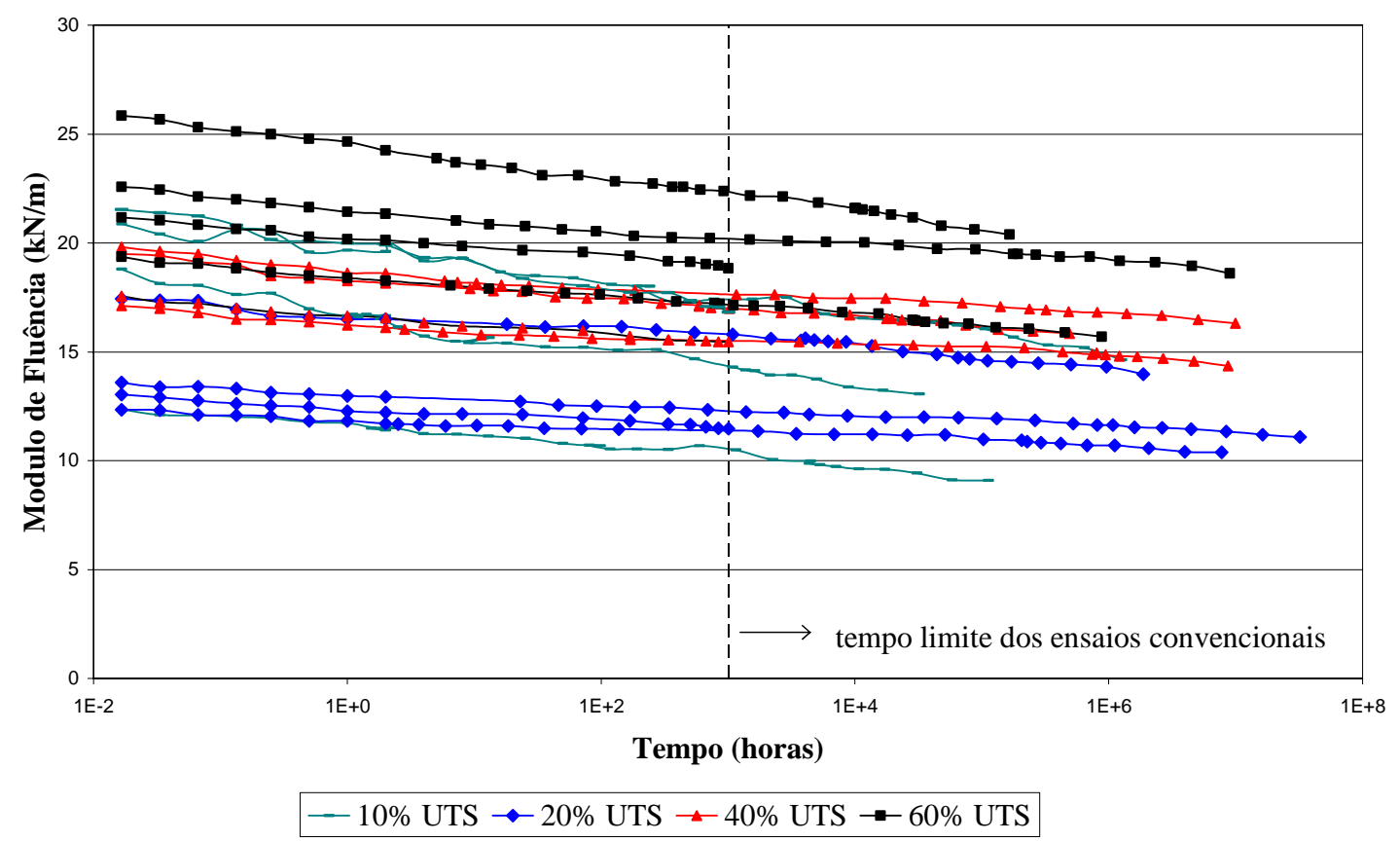

FIGURA 4.8 - Curvas mestras do módulo de fluência obtidas pelo SIM e curvas convencionais para 10, 20, 40 e 60\% UTS para o geotêxtil B.

Os resultados também mostram que para as curvas mestras de poliéster os alcances foram também muito distintos, variando de 4 a 3649 anos. Além dos aspectos já mencionados esta diferença certamente está associada à variabilidade inerente que o material apresenta de amostra para amostra. Na Tabela 4.3, são mostrados os tempos de alcance para cada corpo de prova. Similarmente ao observado para o PP, visualmente podese perceber uma ótima concordância entre os valores obtidos pelos métodos SIM e convencionais. Para analisar os dados utilizaram-se também os coeficientes das retas obtidos através de regressão linear para todos os ensaios, Tabela 4.4. 
TABELA 4.3 - Resultados dos tempos de alcance do geotêxtil B.

\begin{tabular}{|c|c|c|c|}
\hline $\begin{array}{c}\text { Carregamento } \\
\text { (UTS) }\end{array}$ & $\mathbf{C P}$ & Tipo de ensaio & $\begin{array}{c}\text { Tempo de alcance } \\
\text { (anos) }\end{array}$ \\
\hline \multirow{4}{*}{$10 \%$} & $1 \mathrm{~B}$ & Convencional & - \\
\hline & $2 \mathrm{~B}$ & SIM & 13 \\
\hline & $3 B$ & SIM & 4 \\
\hline & $4 \mathrm{~B}$ & SIM & 144 \\
\hline \multirow{4}{*}{$20 \%$} & $5 B$ & Convencional & - \\
\hline & $6 \mathrm{~B}$ & SIM & 886 \\
\hline & $7 \mathrm{~B}$ & SIM & 213 \\
\hline & $8 B$ & SIM & 3649 \\
\hline \multirow{4}{*}{$40 \%$} & $9 B$ & Convencional & - \\
\hline & 10B & SIM & 56 \\
\hline & 11B & SIM & 994 \\
\hline & 12B & SIM & 1138 \\
\hline \multirow{4}{*}{$60 \%$} & $13 \mathrm{~B}$ & Convencional & - \\
\hline & 14B & SIM & 100 \\
\hline & $15 B$ & SIM & 1024 \\
\hline & $16 B$ & SIM & 19 \\
\hline
\end{tabular}


TABELA 4.4 - Coeficientes obtidos por regressão linear para as curvas do geotêxtil B.

\begin{tabular}{|c|c|c|c|c|c|}
\hline Carregamento & $\mathbf{C P}$ & $\begin{array}{c}\text { Deformação } \\
\text { Inicial (\%) }\end{array}$ & $\mathbf{a}$ & b & $\mathbf{R}^{2}$ \\
\hline \multirow{4}{*}{$10 \%$} & $1 \mathrm{~B}$ & 7,16 & 0,18 & 7,78 & 0,983 \\
\hline & $2 \mathrm{~B}$ & 12,47 & 0,28 & 13,30 & 0,963 \\
\hline & $3 B$ & 8,21 & 0,24 & 9,23 & 0,981 \\
\hline & $4 \mathrm{~B}$ & 7,39 & 0,16 & 7,83 & 0,964 \\
\hline \multirow{4}{*}{$20 \%$} & $5 B$ & 23,65 & 0,27 & 24,90 & 0,977 \\
\hline & $6 B$ & 24,99 & 0,20 & 25,98 & 0,959 \\
\hline & $7 \mathrm{~B}$ & 17,69 & 0,21 & 18,41 & 0,943 \\
\hline & $8 B$ & 22,69 & 0,21 & 23,64 & 0,987 \\
\hline \multirow{4}{*}{$40 \%$} & $9 B$ & 35,12 & 0,42 & 37,08 & 0,994 \\
\hline & $10 \mathrm{~B}$ & 31,63 & 0,40 & 33,51 & 0,992 \\
\hline & 11B & 36,05 & 0,27 & 37,86 & 0,956 \\
\hline & 12B & 31,13 & 0,29 & 32,90 & 0,974 \\
\hline \multirow{4}{*}{$60 \%$} & $13 \mathrm{~B}$ & 43,70 & 0,45 & 45,43 & 0,990 \\
\hline & $14 \mathrm{~B}$ & 47,78 & 0,59 & 50,13 & 0,989 \\
\hline & $15 B$ & 41,00 & 0,38 & 43,02 & 0,984 \\
\hline & $16 \mathrm{~B}$ & 35,82 & 0,57 & 37,82 & 0,989 \\
\hline
\end{tabular}

As curvas convencionais e as obtidas pelo SIM mostram uma boa concordância (Figura 4.7). As diferenças entre curvas de mesmo UTS diferenciam-se basicamente na deformação inicial, mas diferentemente do polipropileno, observa-se uma maior variabilidade dos resultados. Apenas para o ensaio de $20 \%$ UTS os coeficientes angulares foram homogêneos. Os ensaios de 10, 40 e 60 \% UTS apresentam discrepâncias nos coeficientes angulares. Apesar disso, os coeficientes angulares tendem a crescer com o aumento do nível de carregamento. O aumento do nível de carregamento acarreta também o aumento da deformação inicial. 


\subsubsection{Curvas isócronas dos geotêxteis ensaiados}

A partir dos resultados dos ensaios de fluência é possível obter as curvas isócronas, que exprimem relação entre a carga de tração aplicada e a deformação axial do geossintético para um tempo pré-determinado. As curvas isócronas são utilizadas para se definir as deformações de projeto de estruturas de solo reforçado na condição de estado de limite de serviço, como mostrado por JEWELL (1996) e PALMEIRA (1999).

As curvas isócronas são obtidas a partir de pares de pontos tomados de curvas de fluência (deformação específica versus tempo) para um tempo fixo. Como ilustração apresentam-se nas Figuras 4.9 e 4.10 curvas isócronas referentes aos materiais A e B, respectivamente. A Figura 4.9 foi construída a partir de resultados obtidos nos ensaios 3A, 6A, 12A e 16A, e a Figura 4.10, com os ensaios 4B, 6B, 11B e 15B.

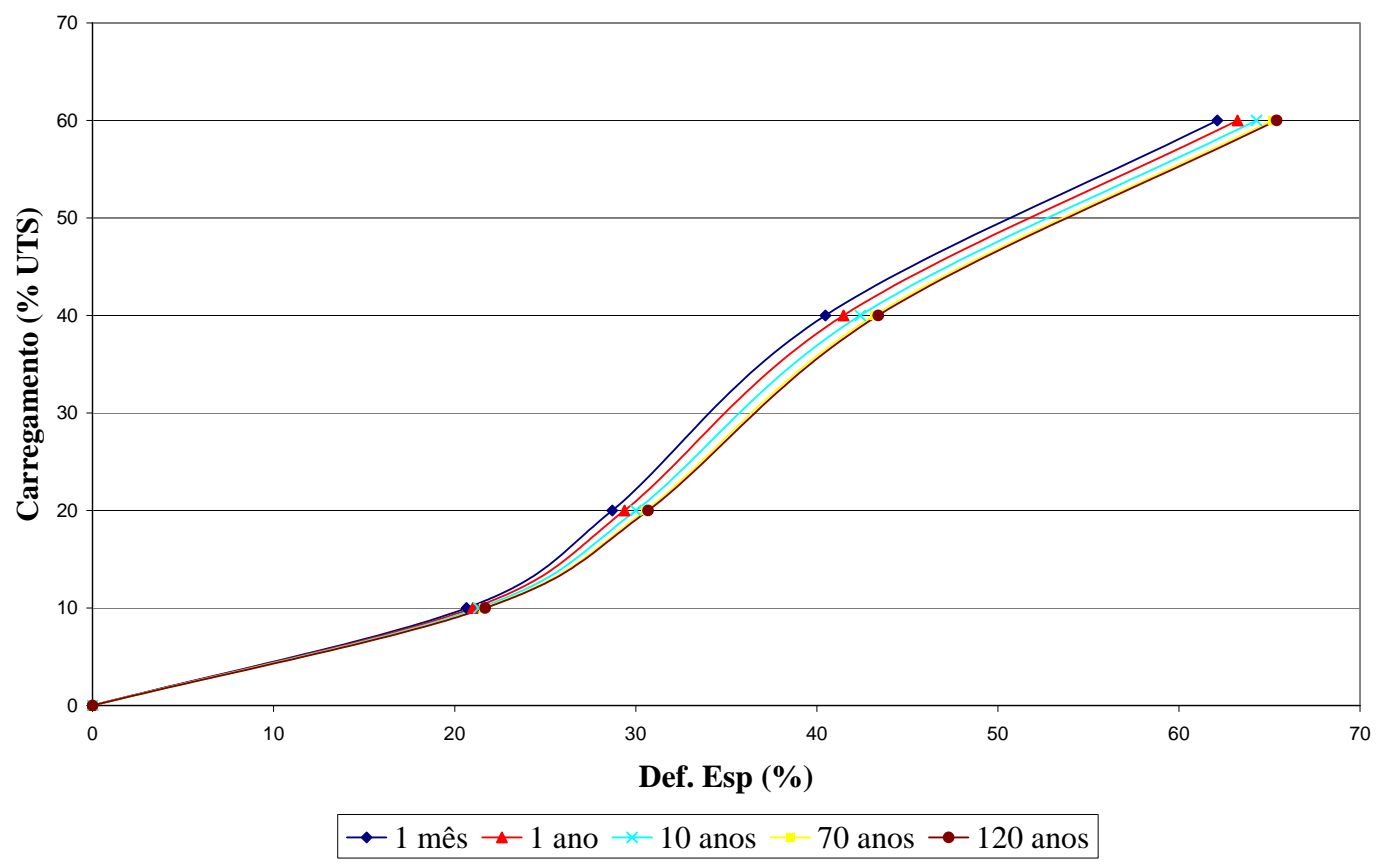

FIGURA 4.9 - Curvas isócronas para o geotêxtil A, obtidas dos ensaios 3A, 6A, 13A e $16 \mathrm{~A}$. 


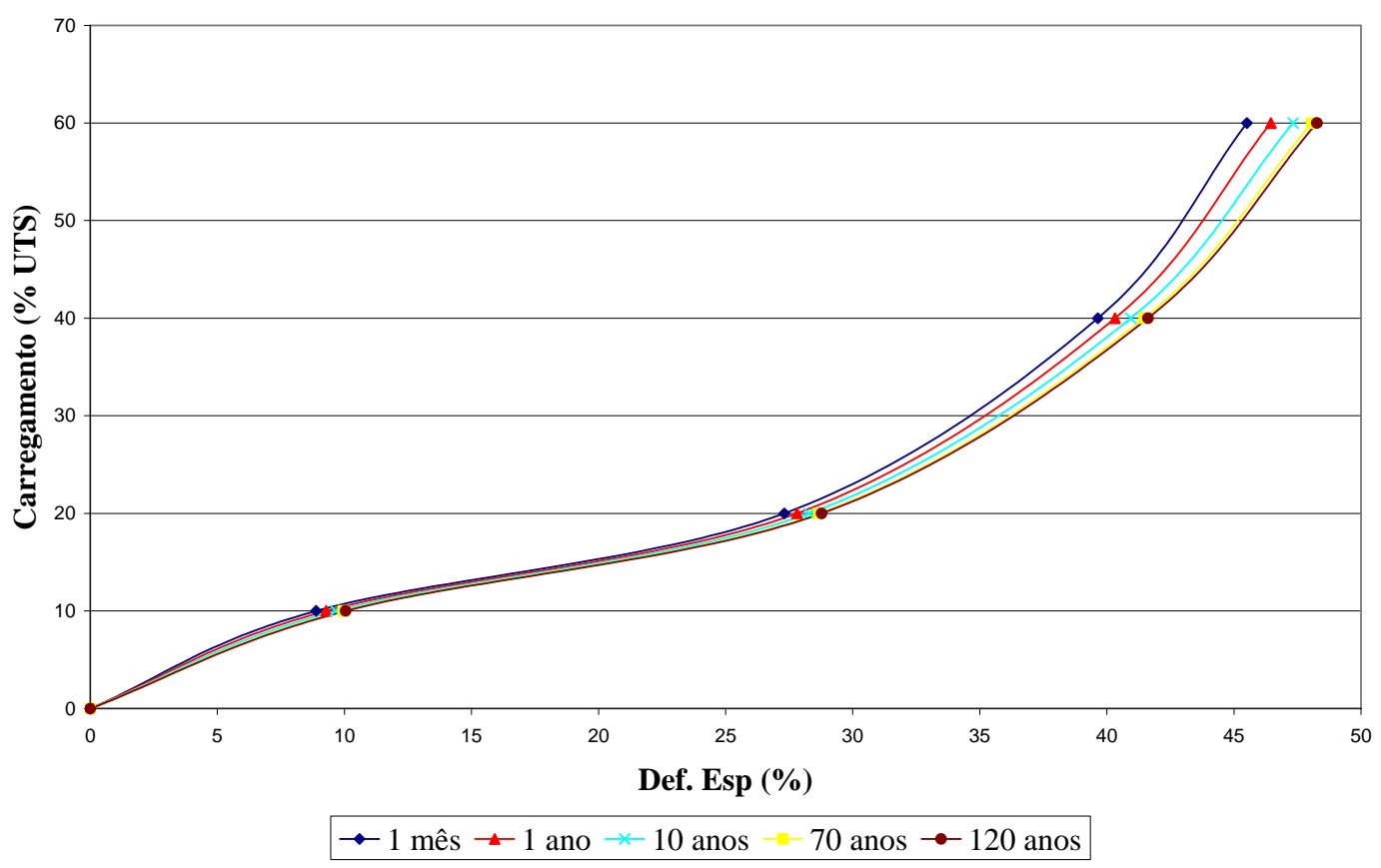

FIGURA 4.10 - Curvas isócronas para o geotêxtil B, obtidas dos ensaios 4B, 6B, 11B e $15 B$.

Os resultados mostram que, para ambos os materiais, até cerca de 20 a $25 \%$ de deformação não há praticamente distinção entre as várias curvas isócronas para um mesmo material. A partir desta deformação, os resultados apontam a existência de uma leve perda de rigidez com o aumento da carga aplicada.

\subsubsection{Deformação transversal das amostras dos geotêxteis ensaiados}

Através dos resultados dos ensaios de fluência é possível medir as deformações que ocorrem no sentido transversal do corpo de prova. Essa medida é chamada de estricção e refere-se ao encurtamento do material na dimensão horizontal no centro do corpo de prova, expressa em porcentagem da largura inicial, Figura 4.11. Os valores do encurtamento foram também obtidos através do método fotográfico de BUENO (1987). As boas correlações entre os valores observados da estricção dos ensaios convencionais e acelerados podem ser utilizadas como uma forma adicional para validar a utilização do método SIM. As medidas obtidas dos ensaios acelerados referem-se a um tempo equivalente de 1008 horas ou valor 
mais próximo, para que se pudesse fazer uma comparação com os valores obtidos, neste tempo, nos ensaios convencionais.

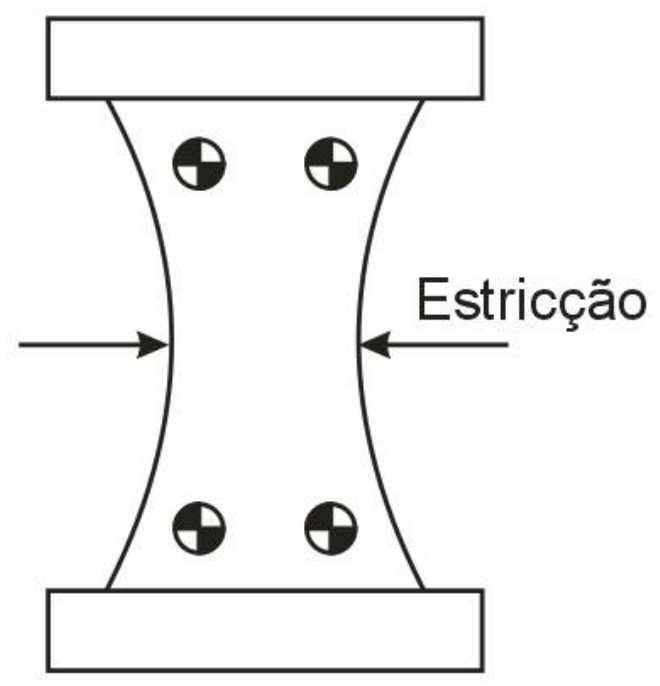

FIGURA 4.11 - Esquema da estriç̧ão ou encurtamento do material na dimensão horizontal no centro do corpo de prova.

Os resultados das estricções para o geotêxtil de polipropileno, em todos os níveis de carregamento, podem ser observados na Figura 4.12. 


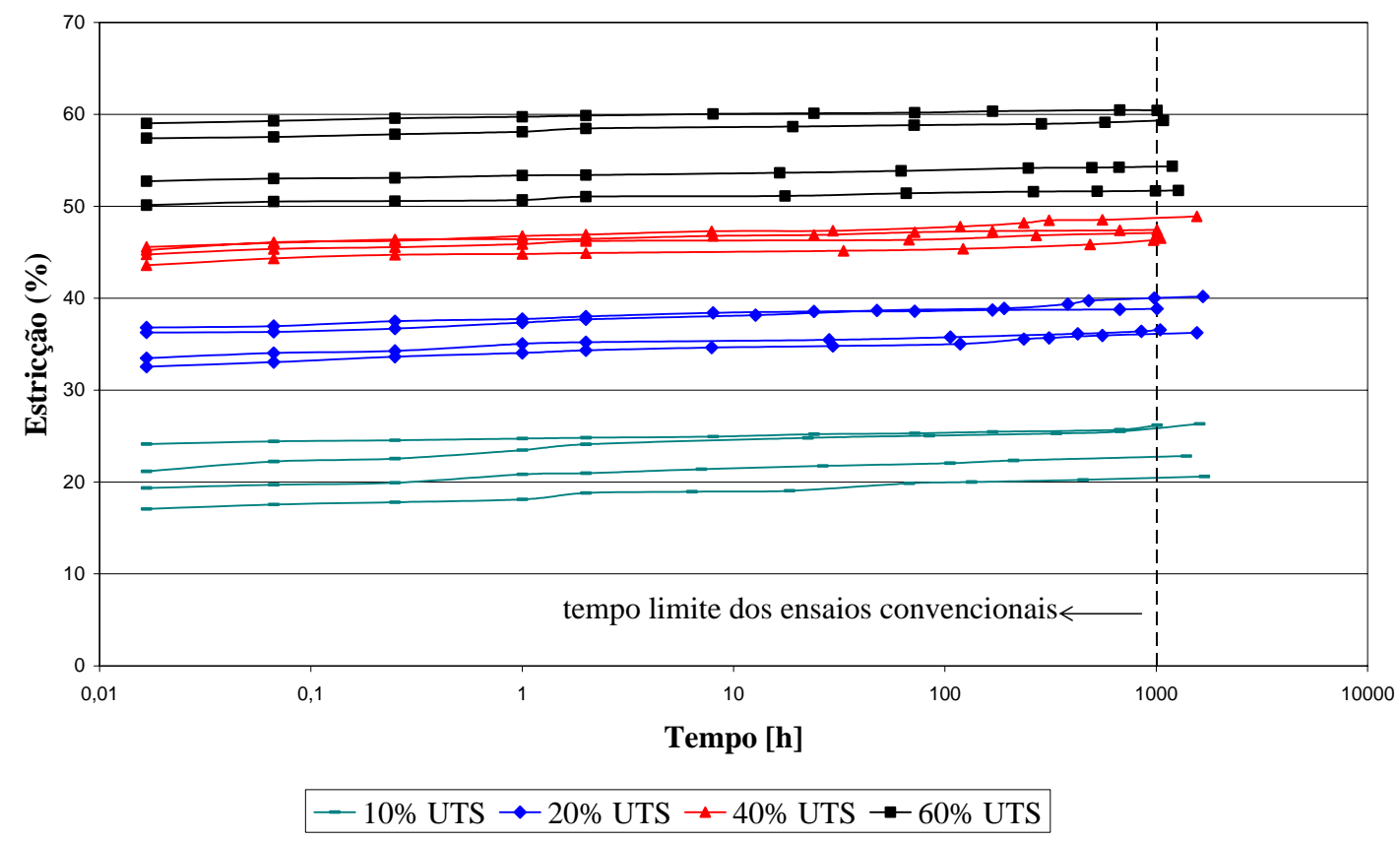

FIGURA 4.12 - Curvas de Estricção obtidas para o material A, para 10, 20, 40 e 60\% UTS.

Os resultados mostraram, similarmente às curvas mestra de fluência, uma ótima concordância entre os ensaios convencionais e acelerados. De forma análoga também houve uma pequena discrepância nos valores de deformação inicial, fato associado, como já referido, possivelmente à heterogeneidade do material.

Semelhantemente ao material A, mediram-se os valores das estricções para o geotêxtil de poliéster, que podem ser vistos na Figura 4.13. 


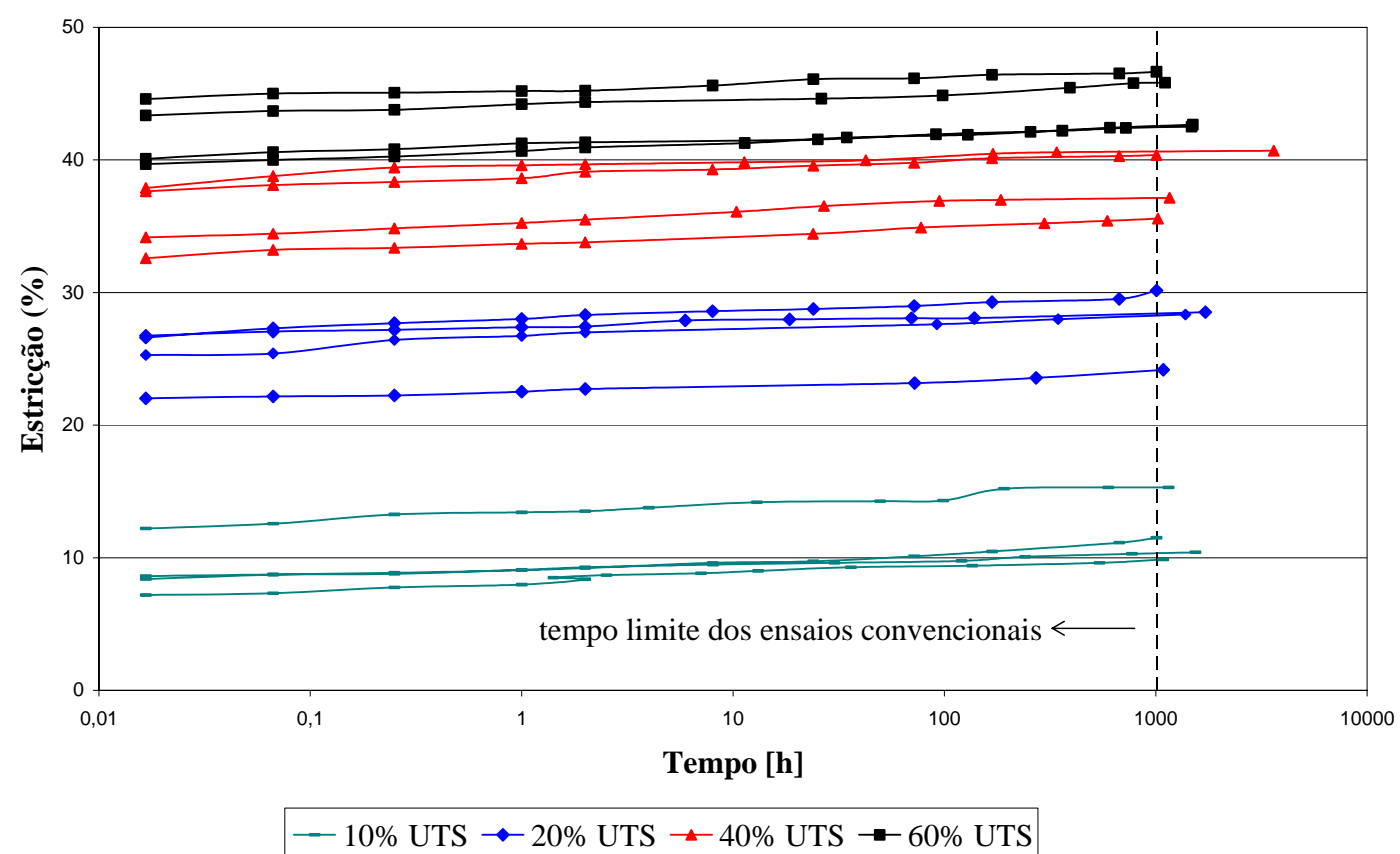

FIGURA 4.13 - Curvas de Estricção obtidas para o material B, para 10, 20, 40 e 60\% UTS.

Os resultados também apontam para uma excelente concordância entre os ensaios convencionais e acelerados. Novamente com pequenas diferenças apenas na deformação inicial.

\subsubsection{Avaliação da taxa de deformação por fluência do material utilizando a equação WLF}

Para se avaliar o acerto do valor de translação horizontal imprimido em cada caso através do ajuste dos coeficientes angulares dos vários trechos da curva mestra de fluência, foram calculados fatores de aceleração através da equação WLF considerando os valores universais de $\mathrm{C} 1$ e C2 como 17,4 e 51,6 ${ }^{\circ} \mathrm{C}$, respectivamente (FERRY, 1980). Os fatores de ajuste experimentais e os valores analíticos estão comparados nas Figuras 4.14 e 4.15 para os geotêxteis de PP e o PET, respectivamente, em função da diferença entre a temperatura do ensaio $(T)$ e a temperatura de referência $\left(T_{r}\right.$ ou $\left.T_{0}\right)$. 


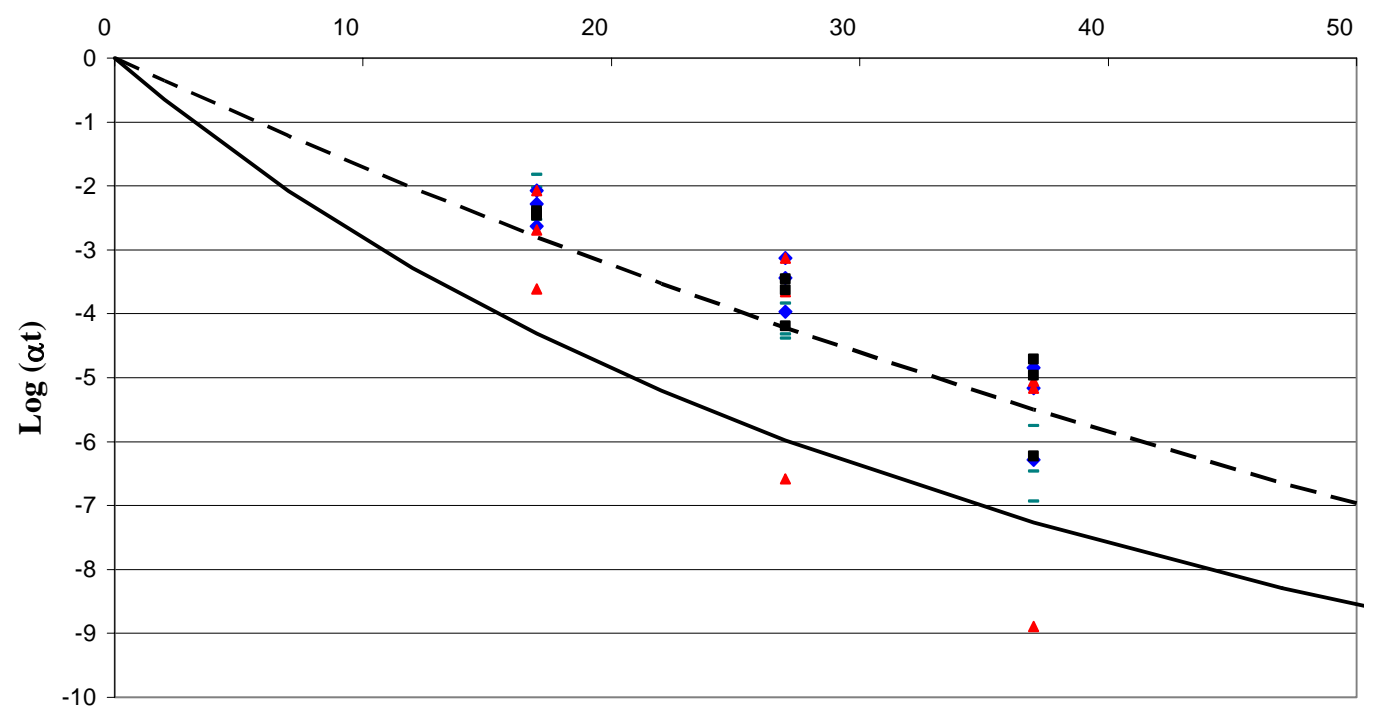

$\operatorname{T-Tr}\left({ }^{\circ} \mathrm{C}\right)$

- $10 \%$ - $20 \%$ \ $40 \%$ - $60 \%$ - Curva Analítica - - Curva Sugerida

FIGURA 4.14 - Curvas Fatores de ajustes, $\alpha$ t, analíticos e experimentais do material A.

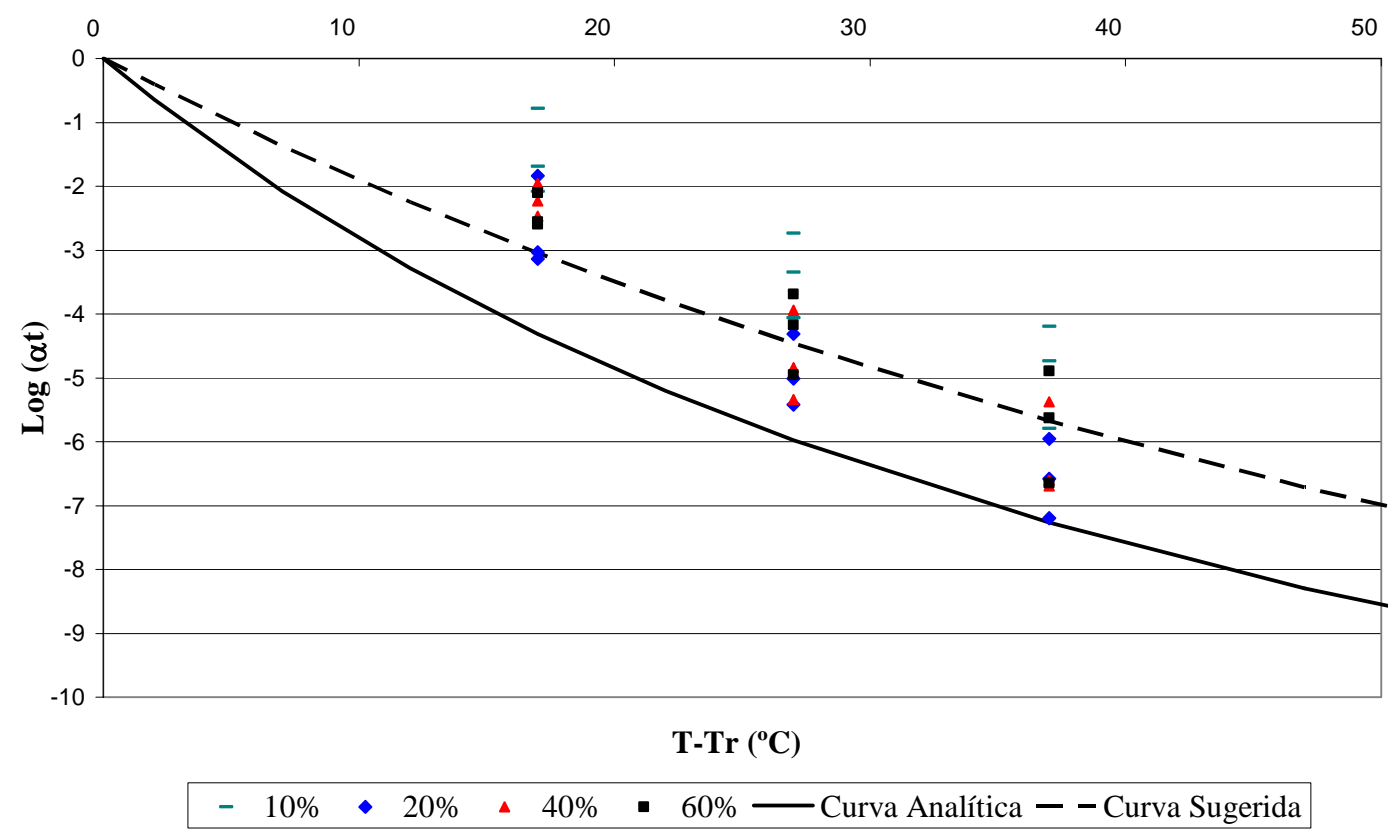

FIGURA 4.15 - Curvas Fatores de ajustes, $\alpha$ t, analíticos e experimentais do material B. 
As figuras mostram que, apesar de haver uma tendência similar no comportamento das duas curvas, não ocorreu uma excelente concordância entre os valores experimentais e analíticos. Esta discrepância possivelmente se deve ao fato da curva analítica ter sido desenhada utilizando coeficientes de C1 e C2, com os valores denominados universais, ou seja, valores constantes, independentes do tipo de polímero utilizado na fabricação dos geossintéticos. No entanto se sabe que estes valores de fato variam, ainda que suavemente, de acordo o tipo de polímero empregado, com a sua temperatura de transição vítrea e, no caso dos geotêxteis, com a formulação química da matéria prima básica que contém aditivos para ajustar suas propriedades de engenharia.

Apenas para efeito ilustrativo, foi realizada uma análise comparativa entre a curva sugerida e a curva analítica, nos pontos de interesse do material (faixa de temperatura dos pontos experimentais). Os resultados mostram que o erro de previsão variou de 24,4 a 35,0\% para o polipropileno e 21,9 e 29,2\% para o poliéster.

Tendo em vista a discrepância observada entre as curvas analítica e experimental e o fato dos coeficientes C1 e C2 serem característicos de cada material, sugere-se que para os geotêxteis ensaiados eles possam ser tomados como 30 e $165^{\circ} \mathrm{C}$ para o polipropileno e 21 e $100^{\circ} \mathrm{C}$ para o poliéster, respectivamente.

\subsection{Ensaios de ruptura por fluência}

\subsubsection{Ensaios de ruptura por fluência do material A}

Foram executados 15 ensaios de ruptura por fluência, sendo 6 deles convencionais, três para o nível de carregamento de 90\% UTS e três para 85\% UTS, e 9 acelerados utilizando o método SIM, para os níveis de carregamento de 75\%, 70\% e 65\% UTS, também três para cada nível. Os ensaios convencionais foram realizados na prensa e os acelerados na câmara de temperatura controlável.

Nos ensaios, de ruptura por fluência acelerados, o mesmo princípio de superposição tempo-temperatura (SIM) aplicado para obtenção das curvas mestra dos ensaios de fluência foi utilizado, mas agora para obtenção dos tempos de ruptura do geotêxtil. Os resultados obtidos para o geotêxtil de polipropileno podem ser visualizados na Tabela 4.5. 
TABELA 4.5 - Tempos de Ruptura obtidos para o geotêxtil A.

\begin{tabular}{|c|c|c|c|c|}
\hline $\begin{array}{c}\text { Nível de } \\
\text { carregamento } \\
\text { (UTS) }\end{array}$ & $\mathbf{C P}$ & Tipo de ensaio & $\begin{array}{l}\text { Tempo de } \\
\text { ruptura } \\
\text { registrado } \\
\text { (horas) }\end{array}$ & $\begin{array}{l}\text { Tempo de ruptura } \\
\text { previsto pelo } \\
\text { método SIM } \\
\text { (horas) }\end{array}$ \\
\hline \multirow{3}{*}{$90 \%$} & $17 \mathrm{~A}$ & Convencional & 0,02 & - \\
\hline & $18 \mathrm{~A}$ & Convencional & 0,03 & - \\
\hline & $19 \mathrm{~A}$ & Convencional & 0,04 & - \\
\hline \multirow{3}{*}{$85 \%$} & $20 \mathrm{~A}$ & Convencional & 0,13 & - \\
\hline & $21 \mathrm{~A}$ & Convencional & 0,25 & - \\
\hline & $22 \mathrm{~A}$ & Convencional & 1,67 & - \\
\hline \multirow{3}{*}{$75 \%$} & $23 \mathrm{~A}$ & Acelerado & 13,48 & - \\
\hline & $24 \mathrm{~A}$ & Acelerado & * & $*$ \\
\hline & $25 \mathrm{~A}$ & Acelerado & 12,06 & 32 \\
\hline \multirow{3}{*}{$70 \%$} & $26 \mathrm{~A}$ & Acelerado & 19,05 & 14.046 \\
\hline & $27 \mathrm{~A}$ & Acelerado & 9,72 & 101 \\
\hline & $28 \mathrm{~A}$ & Acelerado & 34,25 & 699.136 \\
\hline \multirow{3}{*}{$65 \%$} & $29 \mathrm{~A}$ & Acelerado & 33,67 & 72.403 \\
\hline & $30 \mathrm{~A}$ & Acelerado & 15,20 & 2.425 \\
\hline & $31 \mathrm{~A}$ & Acelerado & 27,25 & 64.101 \\
\hline
\end{tabular}

* Ruptura Imediata

A Figura 4.16 mostra a curva de ruptura por fluência que relaciona o nível de carregamento aplicado versus o tempo de ruptura, para todas as amostras ensaiadas. Com exceção do corpo de prova 24A que sofreu ruptura imediata, devida, provavelmente, à variabilidade do material, todos os demais romperam depois de algum tempo de aplicação da carga, e por isto foram considerados ensaios de boa qualidade. 


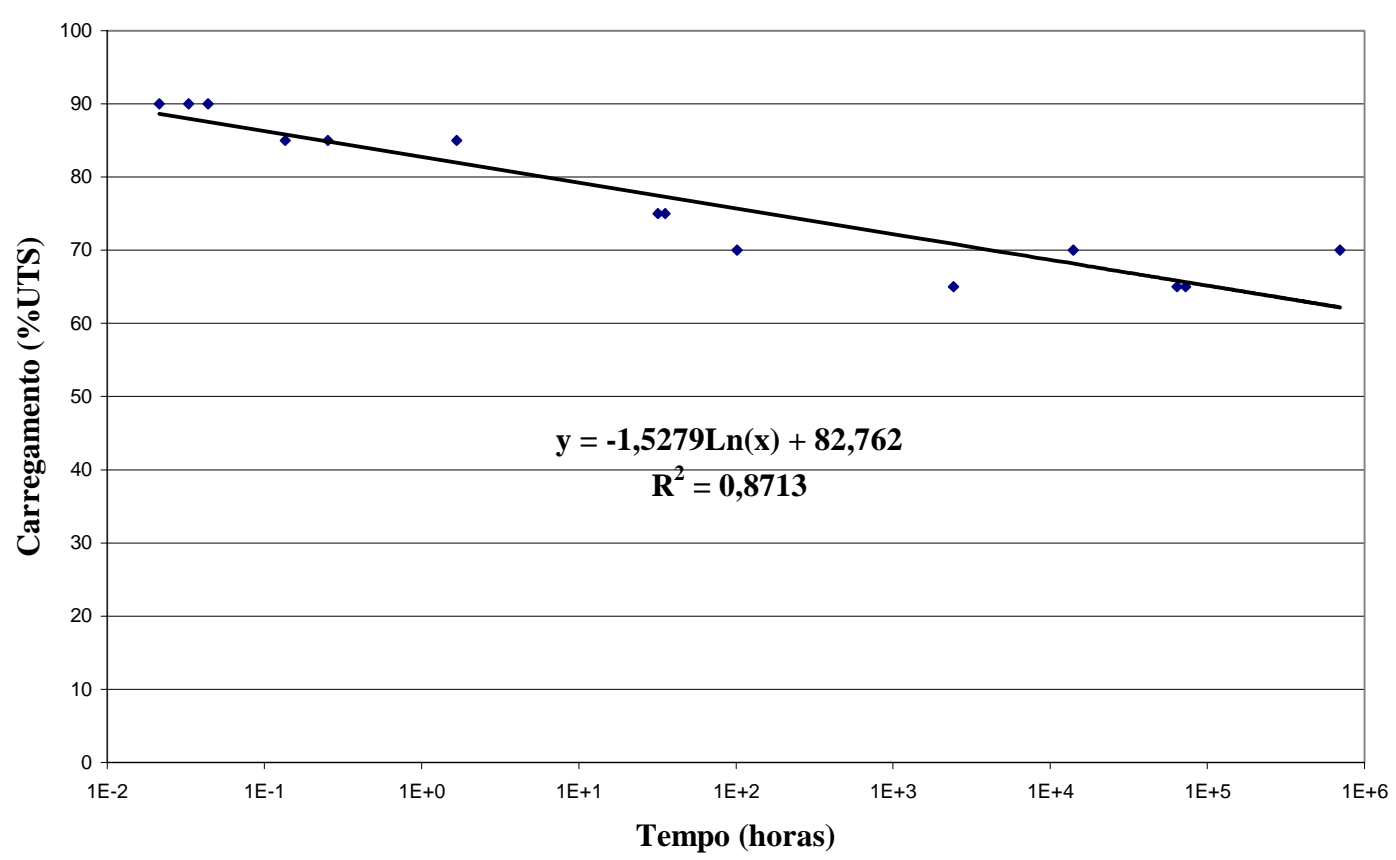

FIGURA 4.16 - Curva de ruptura obtida com uma combinação de resultados de ensaios convencionais e acelerados do material A.

Os resultados obtidos se mostraram coerentes entre si, apesar da variabilidade dos resultados. Pode-se perceber que ocorre um alinhamento nítido das porções da curva de ruptura obtida a partir de resultados de ensaios convencionais e ensaios acelerados de tipo SIM. A figura apresenta a regressão linear, ou linha de tendência, a equação linear correspondente e o coeficiente de correlação da curva obtida. Com relação a esse ajuste realizado, pode-se considerar que a regressão estabelecida foi representativa do comportamento do material, pois o valor de determinação, $\mathrm{R}^{2}$, encontrado permite quantificar a regressão como boa.

\subsubsection{Ensaios de ruptura por fluência do material B}

Analogamente para o produto B, foram executados 15 ensaios de ruptura por fluência, sendo 6 deles convencionais, três para o nível de carregamento de 90\% UTS e três para 85\% UTS, e 9 acelerados utilizando o método SIM, para os níveis de carregamento de 75\%, $70 \%$ e 65\% UTS, também três para cada nível. Mais uma vez, os ensaios convencionais 
foram realizados na prensa e os acelerados na câmara de temperatura controlável utilizando o processo SIM para obtenção dos tempos de ruptura.

A Tabela 4.6 sintetiza os resultados obtidos para o geotêxtil de poliéster.

TABELA 4.6 - Tempos de Ruptura obtidos para o geotêxtil B.

\begin{tabular}{|c|c|c|c|c|}
\hline $\begin{array}{c}\text { Nível de } \\
\text { carregamento } \\
\text { (UTS) }\end{array}$ & $\mathbf{C P}$ & Tipo de ensaio & $\begin{array}{l}\text { Tempo de } \\
\text { ruptura } \\
\text { registrado } \\
\text { (horas) }\end{array}$ & $\begin{array}{c}\text { Tempo de ruptura } \\
\text { previsto pelo } \\
\text { método SIM } \\
\text { (horas) }\end{array}$ \\
\hline \multirow{3}{*}{$90 \%$} & $17 \mathrm{~B}$ & Convencional & 0,02 & - \\
\hline & 18B & Convencional & 0,02 & - \\
\hline & 19B & Convencional & 0,02 & - \\
\hline \multirow{3}{*}{$85 \%$} & $20 \mathrm{~B}$ & Convencional & 1,14 & - \\
\hline & 21B & Convencional & 1,96 & - \\
\hline & 22B & Convencional & 10,17 & - \\
\hline \multirow{3}{*}{$75 \%$} & $23 \mathrm{~B}$ & Acelerado & 13,11 & 138 \\
\hline & $24 \mathrm{~B}$ & Acelerado & 22,77 & 2.117 \\
\hline & $25 B$ & Acelerado & 12,90 & 83 \\
\hline \multirow{3}{*}{$70 \%$} & $26 \mathrm{~B}$ & Acelerado & 49,83 & 86.383 .745 \\
\hline & $27 \mathrm{~B}$ & Acelerado & 48,23 & 57.296 .745 \\
\hline & $28 \mathrm{~B}$ & Acelerado & 45,21 & 12.210 .975 \\
\hline \multirow{3}{*}{$65 \%$} & $29 \mathrm{~B}$ & Acelerado & $60^{*}$ & $377.384 .931 *$ \\
\hline & 30B & Acelerado & 49,50 & 613.109 .228 \\
\hline & $31 \mathrm{~B}$ & Acelerado & 43,20 & 468.032 .448 \\
\hline
\end{tabular}

A Figura 4.17 mostra a curva de ruptura por fluência para todas as amostras ensaiadas do geotêxtil de poliéster. Com exceção do corpo de prova 29B, que não sofreu ruptura no período ensaiado, devido, provavelmente, à variabilidade do material, todos os demais romperam depois de algum tempo de aplicação da carga, e por isto foram também considerados ensaios de boa qualidade. 


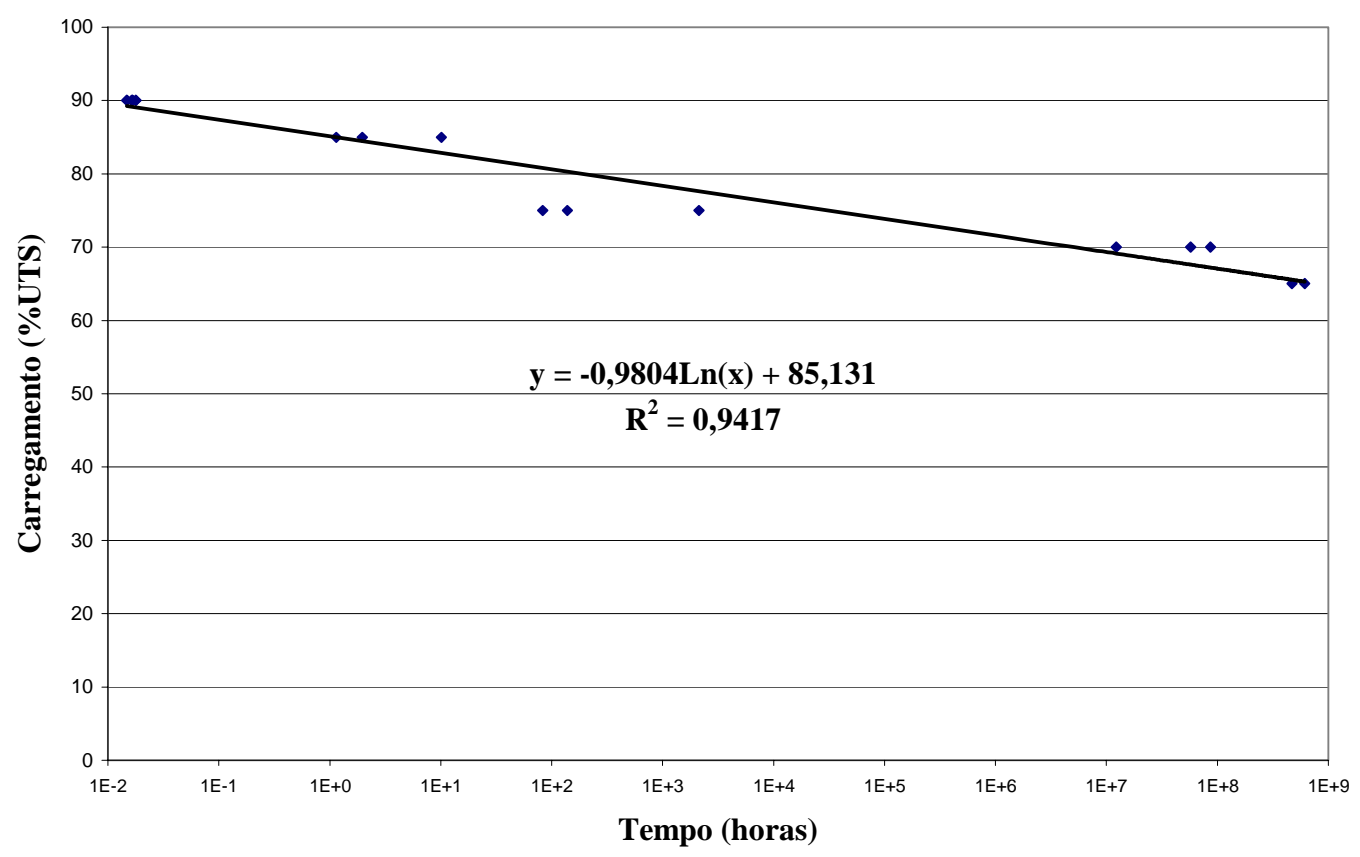

FIGURA 4.17 - Curva de ruptura obtida com uma combinação de resultados de ensaios convencionais e acelerados do material A.

Similarmente ao produto A, os resultados referentes ao produto B obtidos se mostraram coerentes entre si, apesar da variabilidade dos resultados. Pode-se perceber que também ocorre um alinhamento nítido das porções da curva de ruptura obtida a partir de resultados de ensaios convencionais e ensaios acelerados de tipo SIM. Com relação a regressão linear apresentada na figura, pode-se considerá-la de ótima qualidade, pois apresenta um coeficiente de correlação de 0,94.

\subsubsection{Fatores de redução para ruptura por fluência nos geotêxteis ensaiados}

Através das curvas das Figuras 4.15 e 4.16, foram calculados os fatores de redução da resistência à tração dos materiais estudados. Estes fatores são utilizados em projetos, para se levar em conta o efeito da fluência. Esses fatores de redução da resistência à tração devido à fluência alimentam, como visto, a expressão 2.1, para se obter a resistência à tração de projeto. 
A Tabela 4.7 apresenta os fatores de redução da resistência à tração, em virtude da fluência, obtidos considerando diferentes tempos de vida útil para uma suposta estrutura de solo reforçado com os geotêxteis. Esses valores foram obtidos sem a necessidade de extrapolação da curva de ruptura por fluência, uma vez que resultados dos ensaios acelerados ultrapassaram os 120 anos de vida útil estimados para obras desse tipo.

TABELA 4.7 - Fatores de redução em virtude da fluência para o geotêxtil A e B.

\begin{tabular}{|c|c|c|}
\hline \multirow{2}{*}{ Tempo de vida útil (anos) } & \multicolumn{2}{|c|}{ Fatores de redução } \\
\cline { 2 - 3 } & Geotêxtil A & Geotêxtil B \\
\hline 1 & 1,5 & 1,3 \\
\hline 10 & 1,5 & 1,4 \\
\hline 70 & 1,6 & 1,4 \\
\hline 120 & 1,6 & 1,4 \\
\hline
\end{tabular}

Pode-se perceber da análise destes resultados que para o material A os valores mostrados na tabela são muito inferiores aos recomendados na literatura, que variam entre 2,5 e 4,0. Para o geotêxtil B, os valores estão próximos aos valores mínimos recomendados pela literatura, que variam entre 1,5 e 2,5. A adoção desses valores menores implicaria em projetos mais econômicos e também seguros.

Considerando a abordagem utilizada para obtenção dos fatores de redução, percebe-se que não existiu diferenciação significativa no fator a ser adotado considerando os diferentes tempos de vida útil mostrados. 


\subsubsection{Fatores de redução para ruptura por fluência nos geotêxteis ensaiados} considerando-se incertezas da extrapolação

Através das Figuras 4.16 e 4.17 pode-se obter fatores de redução considerando-se as incertezas da extrapolação dos dados e dos ensaios acelerados. Os cálculos das incertezas seguiram a norma BS 8006 (1995).

As Figuras 4.18 e 4.19 mostram, além da curva de ruptura dos materiais, a curva de limite de confiança de 95\%, para o material A e B, respectivamente.

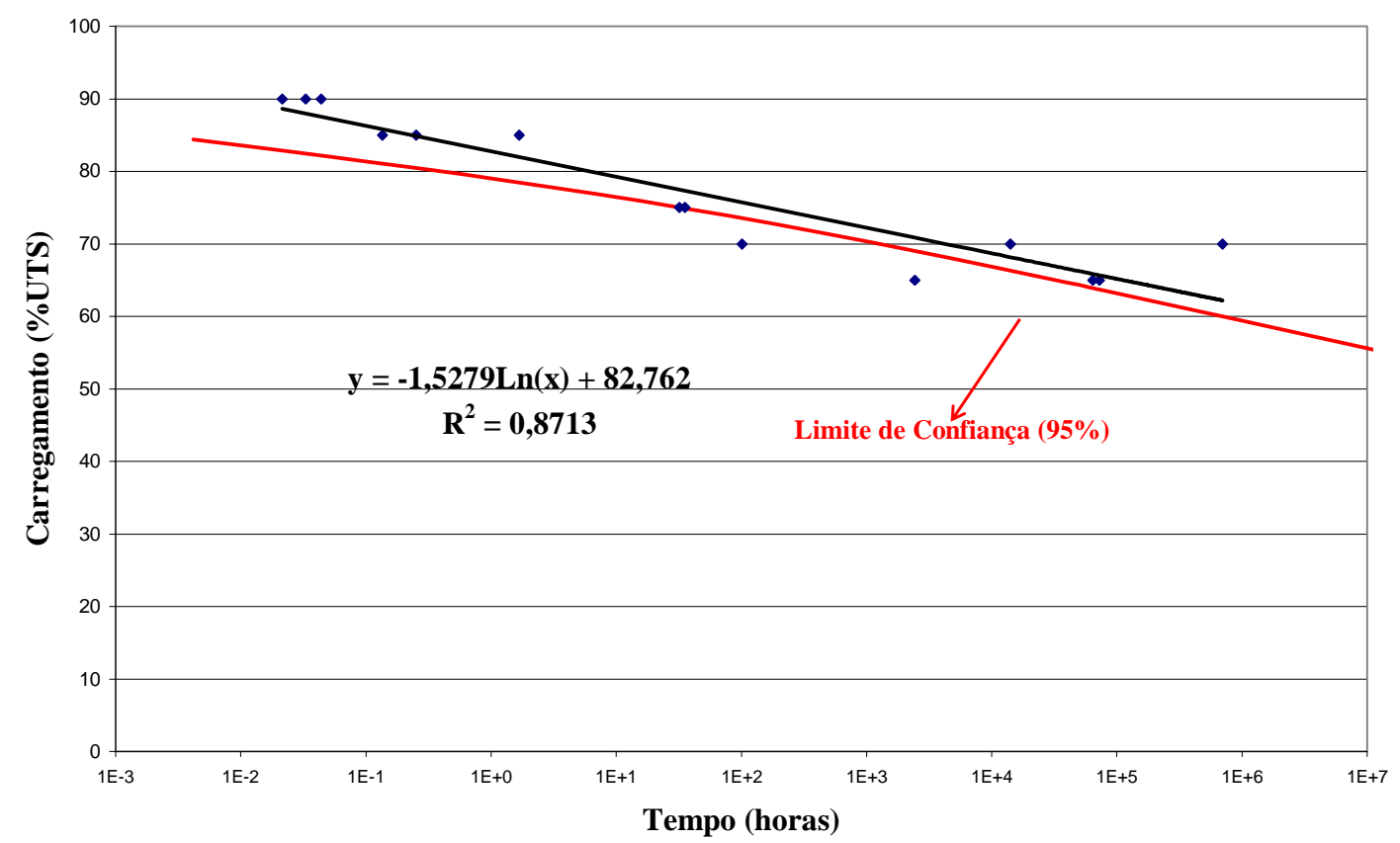

FIGURA 4.18 - Curva de ruptura e Curva do Limite de Confiança de 95\% do material A. 


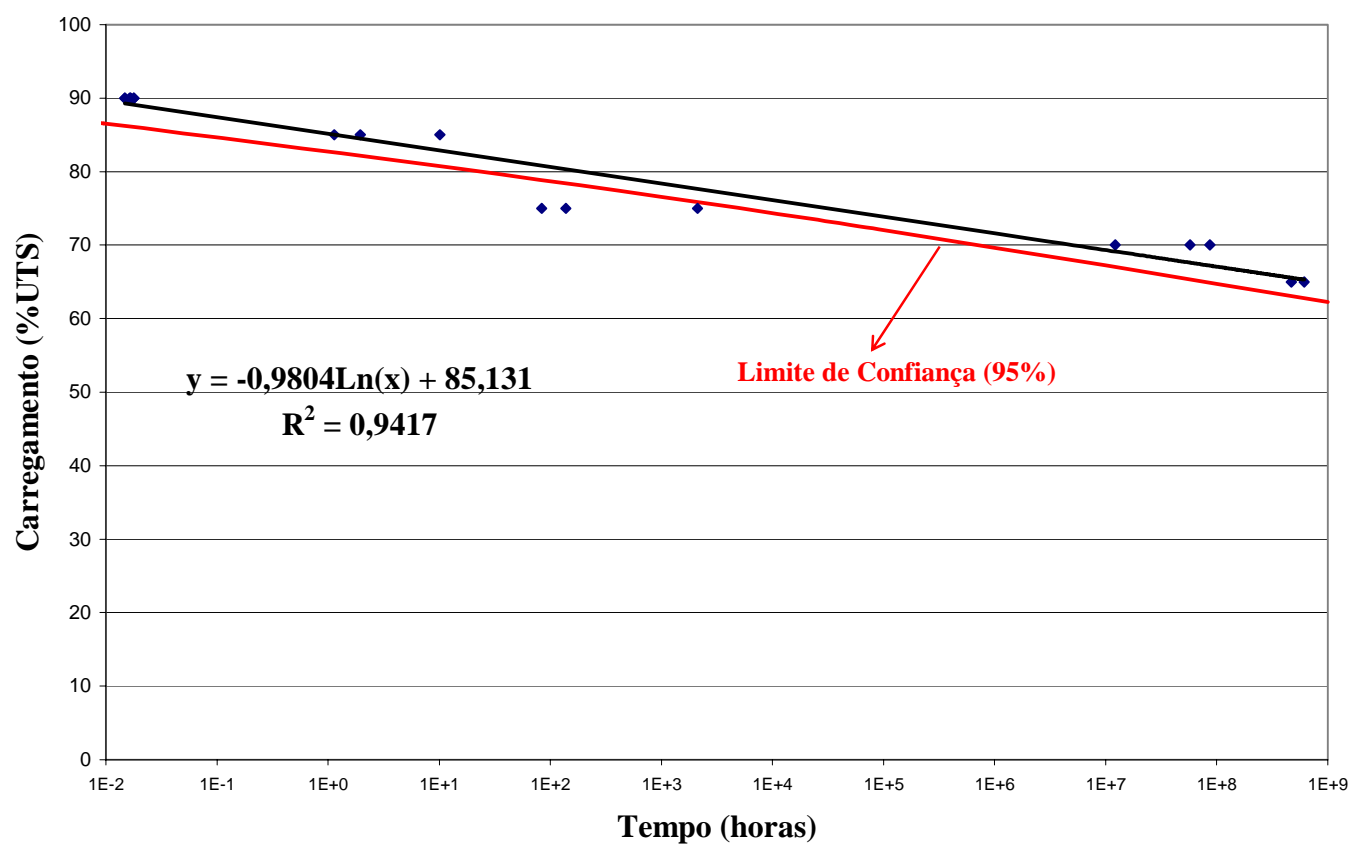

FIGURA 4.19 - Curva de ruptura e Curva do Limite de Confiança de 95\% do material B.

Através das curvas de limite de confiança de 95\%, das Figuras 4.17 e 4.18, foram calculados os fatores de redução à resistência à tração dos materiais estudados. A Tabela 4.8 apresenta estes fatores de redução da resistência à tração considerando-se as incertezas de extrapolação e dos ensaios acelerados.

TABELA 4.8 - Fatores de redução em virtude da fluência para o geotêxtil A e B considerando-se as incertezas das extrapolações e dos ensaios acelerados.

\begin{tabular}{|c|c|c|}
\hline \multirow{2}{*}{ Tempo de vida útil (anos) } & \multicolumn{2}{|c|}{ Fatores de redução } \\
\cline { 2 - 3 } & Geotêxtil A & Geotêxtil B \\
\hline 1 & 1,5 & 1,3 \\
\hline 10 & 1,6 & 1,4 \\
\hline 70 & 1,7 & 1,4 \\
\hline 120 & 1,7 & 1,4 \\
\hline
\end{tabular}

Pode-se perceber que para o material A os valores dos fatores de redução apresentados na tabela são um pouco maiores dos que os valores apresentados sem considerar as 
incertezas, mas são ainda sim muito inferiores aos recomendados pela literatura. Para o geotêxtil B, os valores não se alteraram significantemente e situam-se próximos aos valores mínimos recomendados pela literatura.

Esses valores sofreram pouca variação devido à boa qualidade dos ensaios e ao bom alinhamento dos resultados, o que dá origem a um pequeno desvio dos resultados.

A utilização destes fatores de redução permite projetar com mais confiança, pois os resultados consideram também as incertezas dos resultados dos ensaios. 


\section{CAPÍTULO 5}

\section{CONCLUSÕES E SUGESTÕES PARA PESQUISAS FUTURAS}

\subsection{Conclusões}

No presente trabalho preocupou-se avaliar a utilização do princípio de superposição tempo-temperatura conjuntamente com o método SIM ("Stepped Isothermal Method") na caracterização e simulação do comportamento da fluência e da ruptura por fluência em dois geotêxteis não tecidos. Do exposto no trabalho pode-se concluir que:

a) os valores de deformação por fluência obtidos pelo método SIM foram comparados aos valores obtidos nos ensaios convencionais, realizados segundo a norma ISO 1343, e esses resultados se mostraram válidos para a caracterização do comportamento da fluência de geotêxteis de polipropileno (PP) e de poliéster (PET), sendo que a diminuição do tempo de ensaio ficou evidente. Isto demonstra a eficiência do procedimento experimental utilizado na obtenção de respostas rápidas com relação à caracterização da deformação ao longo do tempo;

b) os resultados mostram que, para ambos os materiais, não há praticamente distinção entre as várias curvas isócronas para um mesmo material, mostrando um comportamento bastante homogêneo, independente do tempo de vida útil;

c) a análise das estriç̧ões medidas nos corpos de provas submetidos aos ensaios convencionais e acelerados auxiliaram na avaliação da similaridade dos procedimentos experimentais utilizados, validando novamente a utilização do método SIM; 
d) as comparações entre os fatores de translação experimentais e analíticos, calculados utilizando valores universais para as constantes C1 e C2, não mostraram boa concordância, sendo que as discrepâncias observadas sugerem que estas constantes devem ser mais bem avaliadas e nesta avaliação deve-se ter em conta os tipos específicos das matérias primas utilizadas na confecção dos geotêxteis;

e) para os ensaios de ruptura, o método também se mostrou eficiente, uma vez que foi obtido um bom alinhamento das curvas de ruptura, de ambos materiais, obtidas com uma combinação de resultados de ensaios convencionais e SIM;

f) os ensaios de ruptura permitiram a determinação de fatores de redução da resistência à tração, sendo que estes estão em sua maioria abaixo ou próximos dos menores valores recomendado na literatura.

\subsection{Sugestões para pesquisas futuras}

a) realizar ensaios de acelerados pelo método SIM em outros tipos de materiais, como geotêxteis tecido e geogrelhas, para um melhor entendimento do comportamento dos resultados e assim testar e aperfeiçoar ainda mais o método;

b) estudar melhor o tipo de polímero utilizado, para obtenção real dos valores das constantes $\mathrm{C}_{1}$ e $\mathrm{C}_{2}$ para uma possível melhor avaliação da equação de WillianLandel-Ferry (WLF);

c) elaborar e ajustar modelo matemático para obtenção do tempo de início virtual. 


\section{REFERÊNCIAS BIBLIOGRÁFICAS}

ABRAMENTO, M. (1995). Durabilidade e comportamento de longo prazo de geossintéticos - parte I: propriedades mecânicas e hidráulicas. In: Geossintéticos'95. Anais. São Paulo, p. 217-226.

ASSOCIAÇÃO BRASILEIRA DE NORMAS TÉCNICAS (1992). NBR 12568 Geotêxteis - Determinação da gramatura. Rio de Janeiro.

ASSOCIAÇÃO BRASILEIRA DE NORMAS TÉCNICAS (1992). NBR 12824 Geotêxteis - Determinação da resistência à tração não confinada - Ensaio de tração de faixa larga. Rio de Janeiro.

ASSOCIAÇÃO BRASILEIRA DE NORMAS TÉCNICAS (1992). NBR 12593 Amostragem e preparação de corpos de prova de geotêxteis. Rio de Janeiro.

ASSOCIAÇÃO BRASILEIRA DE NORMAS TÉCNICAS (1997). NBR 12553 Geossintéticos. Rio de Janeiro.

AMERICAN SOCIETY FOR TESTING AND MATERIALS (1992). ASTM D 5262 Standard test method for evaluating the unconfined tension creep behavior of geosynthetics. In: Annual book of ASTM standards. New York. 
AMERICAN SOCIETY FOR TESTING AND MATERIALS (1992). ASTM D5268 Standard specification for Topsoil Used for Landscaping Purposes In: Annual book of ASTM standards. New York.

BARAS, L. C. S. (2001). Estudo da fluênciaem geotêxteis através de ensaios não confinados convencionais e acelerados. Dissertação de Mestrado. Escola de Engenharia de São Carlos, Universidade de São Paulo.

BARAS, L. C. S.; BUENO, B. S.; COSTA, C. M. L. (2002). On the evaluation of stepped isothermal method for characterizing creep properties of geotextiles. Geosynthetics7th ICG. Swets \& Zeitlinger, Liss ISBN 905809523 1. p.1515-1518.

BALLEGEER, J.P.; WU, T.H. (1993). Intinsic confined and unconfined load-deformation propertties of geotextiles. Geosynthetic soil reinforcement testing procedures. American Society for Testing and Materials. Philadelphia. p. 16-31.

BRITISH STANDARDS INSTITUTION (1995). BS 8006. Code of practice for strengthened/reinforced soils and other fills. London, UK.

BUENO, B. S. (1987). The behaviour of thin walled pipes in trenches. Leeds, Leeds University (theses D.S.). 325p.

CAZZUFFI, D.; GHINELLI, A.;SACCHETTI, M.; VILLA, C. (1997). European experimental approach to the tensile creep behavior of high-strength geosynthetics. In: Geosynthetics'97. Proceedings. California. V. 1, p. 253-266. 
COSTA, C. M. L. (1999). Fluência em geotêxteis. São Carlos. Dissertação de Mestrado. Escola de Engenharia de São Carlos, Universidade de São Paulo.

COSTA, C. M. L. \& BUENO, B. S. (2001). Fluência de Geotêxteis não-tecidos. Revista Solos e Rochas, vol. 23, n 3, pp. 235-246.

CHANG, D.T.; CHEN C.;FU, Y. (1996). The creep behavior of geotextiles under confined and unconfined conditions. Earth Reinforcement. Balkema, Rotterdam. p. 19-24.

CHRISTOPHER, B.R.; GILL, S.A.;GIROUD, J.P.; MITCHELL,J.; SCHLOSSER, F.; DUNNICLIFF, J. (1990). Design and construction guidelines for reinforced soil structures. Federal Highway Administration, U.S. Department of transportation, report n. FHWA-RD-89-043.

DEN HOEDT, G. (1986). Durability of geotextiles. London, Chapman and Hall. P. 34-38. Principles of creep and relaxation.

FARRAG, K.; (1998). Development of na accelerated creep testing proceedure for geosynthetics - Part II: Analysis. Geotechnical testing journal. V.21, n.1, p38-44.

FARRAG, K.; SHIRAZI, H. (1997).Development of a accelerated creep testing proceedure for geosynthetics - Part I: Testing. Geotechnical testing journal. v. 20, n.4, p. 414422.

FERRY, J. D. (1980). Viscoelastic Properties of Polymers. 3rd Edition, John and Sons, New York, NY, USA. 
GREENWOOD, J. H. ; VOSKAMP, W.; Predicting the long-term strenght of a geogrid usind the stepped isothermal method. Second European Geosynthetics Conference. Bologna, Italy, 15-18 october.

HORROCKS, A. R.; D'SOUZA, J. A. (1992). Degradation of polymer in geomembranes and geotextiles. In: HAMID, S.H. et al. Handbook of polymer degradation. New York, Marcel Dekker. Cap. 15, p. 433-505.

INTERNATIONAL ORGANIZATION FOR STANDARTDIZATION (1998). ISO 13431

- Geotextile and geotextile-related products - Determination of tensile creep and creep rupture behaviour. Switzerland.

JEWELL, R.A.; GREENWOOD, J.H. (1988). Long term strength and safety in steep soil slopes reinforced by polymer materials. Geotextiles and Geomembranes, v. 7, n. 1 e 2, p. 81-118.

JEWELL, R.A. (1996). Soil reinforced with geotextiles. London, Ciria.

KOERNER, R.M. (1994). Designing with geosynthetics, Englewood Cliffs, New Jersey, Prentice Hall, 3rd Ed.

KOERNER, R.M.; LORD, A.E.Jr.; HALSE,Y.H. (1988). Long term durability and aging of geotextiles. Geotextiles and Geomembranes, v. 7, p. 147-158.

KOERNER, R.M.; SOONG,T.; KOERNER, G.R.; GONTAR,A. (2001). Creep testing and data extrapolation of reinforced GCLs. Geotextiles and geomembranes. n. 16. p. 365-382 
LEVACHER, D.; BLIVET, J. C.; MSOUTI, F. (1994). Tensile and creep behavior of geotextiles. In: Geotextiles, geomembranes and Relates Products, 5th, Reinforcement applications and related research.. Proceedings Singapore. v. 3, p. $1131-1134$.

MANO, H.B. (1991). Polímeros como material de engenharia. São Paulo, Editora Edgard Blücher Ltda.

MATICHARD, Y.; LECLERQ, B.; SEGOUIN, M. (1990). Creep of geotextiles: soil reiforcement applications. In: Geotextiles, geomembranes and products, 4th, The Hague. Proceedings. Balkema, Rotterdam, Netherland.

McGOWN, A.; ANDRAWES, K.Z.; KABIR, M.H. (1982). Loas-extension testing of geotextiles confined in soil. In: International Conference on Geotextiles, 2nd. Proccedings. Las Vegas, v.3, p. 793-798.

MIKI, H.; HAYASHI, Y.; YAMADA, K.;TAKASAGO, T.; SHIDO, H. (1990). Plane strain tensile strenght and creep of spun-bonded non-wovens. In: Geotextiles, geomembranes and Relates Products, 4th, The Gague. Proceedings Rotterdam, Balkema. v. 2, p. 667-672.

MSOUTI, M.F., BLVET,J.C.; LEVACHER, D. (1997). Comportament au fluage des géotextiles en reforcement mécanique. Études et recherches des laboratories des Ponts et Chaussées, GT n. 63. 
MÜLLER-ROCHHOLZ , J.; KOSLOWSKI C. (1996). Creep predction. In: European Geosynthetics Conference, 1. Proceedings. Netherland. p. 1027-1030.

PALMEIRA , E. M. (1999). Solo Reforçado. Husker Ltda.

RECKER, C.; MÜLLER-ROCHHOLZ , J. (1996). The creep behavior of geotextiles in soil (short-time tests and long time tests). Geosynthetics: Applications, Desing and Construction. Balkema, Rotterdam. p 229-233.

SAWICKI, A.; KAZIMIEROWICZ-FRANKOWSKA, K. (1998). Creep behavior of geosynthetics. Geotextiles and geomembranes. n. 16. p. 365-382

SEGRESTIN, P.; JAILLOUX J-M. (1988). Temperature in soils and its effecte on the ageing of synthetic materials. Geotextiles and Geomembranes, v. 7, p. 51-69.

SHRESTHA, S. C.; BELL, J. R. (1982). Creep behavior of geotextiles under sustained loads. In: International conference on geotextiles, 2nd. Proceedings. Lãs Vegas, v. 3, p. 769-774.

THORNTON, J. S.; ALLEN, S. R.; THOMAS, R. W. (1997). Approaches for the prediction of long term viscoelastic properties of geosynthetics form short term tests. In: Geosynthetics for soil reinforced; Leatherhead, 1997. Proceedings. ERA Report 98-0015, p.2.1-2.9.

THORNTON, J. S.(1998). The stepped isothermal method (SIM) for time-temperature superposition. In: Creep and Assessment of geossynthetics for Soil Reinforcement; Leatherhead. Proceedings. Reaport 98-0015. 
THORNTON, J. S.; ALLEN, S. R.; THOMAS, R. W.; SANDRI, D. (1998). The Stepped Isothermal Method for Time-Temperature Superposition and Its Aplication to Creep Data on Polyester Yarn. In: Sixth International Conference on Geosynthetics, p.699706.

TUPA, N. \& PALMEIRA, E.M. (1995). Comportamento de geotêxteis não tecidos confinados em solos finos. In: Geossintéticos'95. Anais.São Paulo, p. 139-147.

WU, C.S. \& HONG, Y. S. (1994). Creep behavior of geotextile under confining stress. In: Geotextile, Geomembranes and Related Products, 5th. Proceedings. Singapore, v.3, p. $1135-1138$.

WU, J.T.H.(1994). Floor discussion on long-term creep behavior. International Symposium on recent case histories of permanent geosynthetic-reinforced soil retaining walls. Rotterdam ; A.A. Balkema. p. 343-344. 